(2)

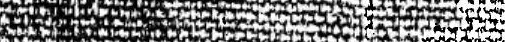

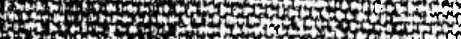

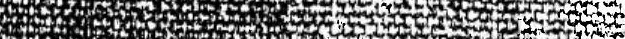

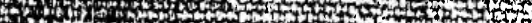

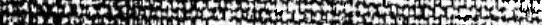
(1)

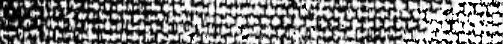
1. 1.5.

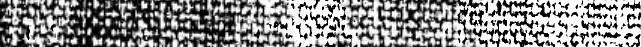

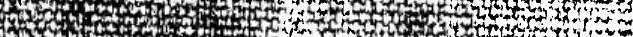

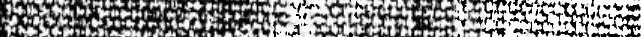

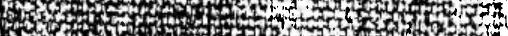

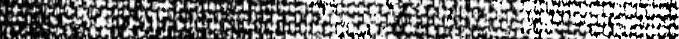
140 . 3. in

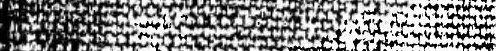

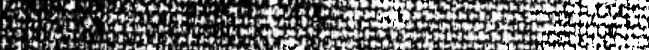

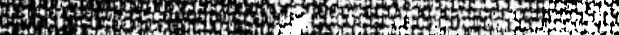

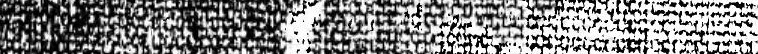

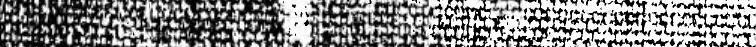

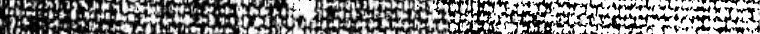

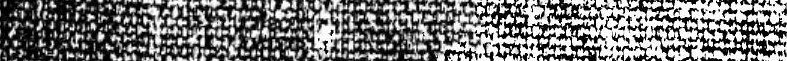
1. ${ }^{2}$.

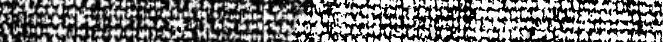

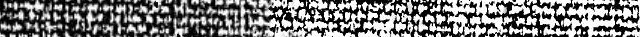
19. A. 3 .

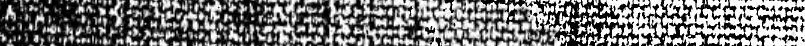
1.

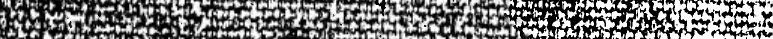
7. 14.20 3. if $\therefore$ H.

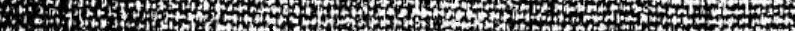
1020 .

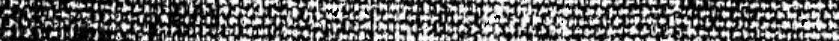
4. 27. n

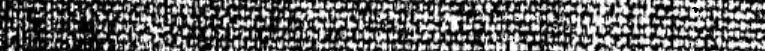

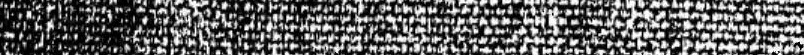

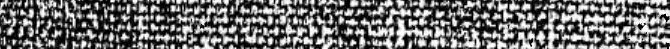

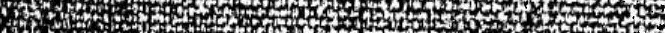

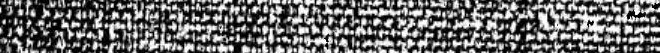

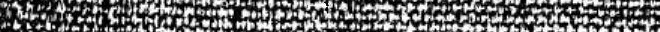
N.

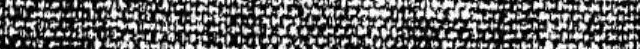
14.

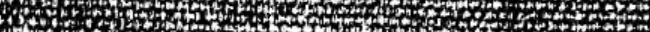

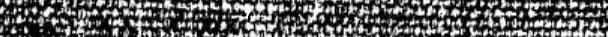
70 .

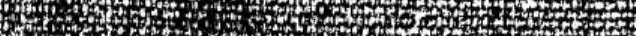

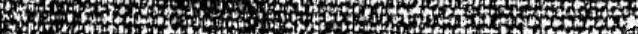

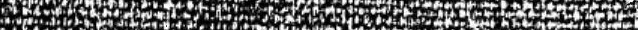

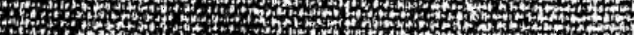
10.4. 
<smiles>C=CCCC</smiles> 






\title{
Christian SCIENCE
}

THE FAITH AND ITS FOUNDER

\author{
BY \\ LYMAN P. POWELL
}

Rector of St. John's Church, Northampton, Massachusetts

G. P. PUTNAM'S SONS NEW YORK AND LONDON Tbe $\mathbb{1 k n i c k e r b o c k e r ~} \mathbb{p r e s s}$ I 907 
COPYRIGHT, IgO7 BY

G. P. PUTNAM'S SONS

Tbe Tknickerbocker Press, Mew york 


\section{PREFACE}

\section{CHRISTIAN SCIENCE has long en-}

gaged my interest. For years I discouraged none who sought its healing ministry. The undiscriminating censure visited upon it in apparent ignorance or prejudice made no impression on me. The desire Christian Scientists were constantly expressing to be judged by their fruits seemed to me to be both Christian and scientific.

A year or two ago, however, closer observation and more serious consideration brought me to three conclusions which appear to me unquestionably true:

1. That when members of any Christian church turn to Christian Science healing they usually turn away from historic Christianity.

2. That there are in the theory of Christian Science certain structural weaknesses which may easily be overlooked by people unschooled in philosophy, theology, or science.

3. That the answers of the accredited exponents of the movement to the criticisms 
which are steadily gaining headway satisfy none save Christian Scientists and such others as read carelessly and think loosely.

This volume grew out of a booklet of mine which was never regularly published, but for which there soon came to be a large demand from all parts of the country. It was at the suggestion, altogether unexpected, of G. P. Putnam's Sons that I have expanded the monograph into a book.

My purpose, as the reader will discover, has been to write a book in which the average man who is outside of Christian Science can find the things he wants to know about its theory and practice. If to my readers it may now and then appear that I unduly emphasise the defects of the system, I ask them to observe that the good in Christian Science is the good in other religions and therefore requires no special emphasis, while the evil is distinctive and needs analysis and publicity to make it evident.

In studying the theory of Christian Science I have read various editions of Science and Health, covering its entire development, together with other writings of Mrs. Eddy, and the literature, now abundant, both in explanation and in criticism of the system. To read- 
ing I have added interviews and correspondence with representative apologists and critics of the movement.

In considering Mrs. Eddy's personal history, I have made free use of Georgine Milmine's articles in McClure's. I have taken the pains, however, in each instance to verify her statements by correspondence or by interviews with those concerned. For this purpose alone I have travelled more than twenty-five hundred miles and am glad to be able to testify to the singular accuracy of the articles and the thoroughness with which they have been prepared.

In the chance that there might be witnesses whom Georgine Milmine overlooked to contradict the witnesses she introduces in the open court of a great magazine, I took counsel with the Committee on Publication of the Christian Science organisation. He referred me to the author of the Human Life articles on the same subject, but I was no more fortunate with her than with the Committee. I am, therefore, satisfied, so far as it is possible to be, that there is no significant evidence to offset the evidence presented in McClure's.

To name all who have in one way or another helped me in my work would be impossible. 
But I must at least mention the following to whom I am especially indebted: Mr. Alfred Farlow, Mrs. Benjamin Welles, Mr. George A. Quimby, Mr. F. W. Peabody, Professor R. W. Micou, Rev. Dr. C. E. Holmes, Rev. Dr. A. E. Dunning, Mr. George Perry Morris, Mr. Horatio W. Dresser, Dr. A. MI. Cushing, Mr. Livingston Wright, Rev. John Snyder, Rev. Wm. L. Chaffin, Mr. Robert K. Shaw, Rev. Dr. J. M. Buckley, Rev. Dr. S. A. Eliot, Rev. Dr. E. H. Delk, Mr. Richard Kennedy, Mr. Daniel H. Spofford, Mrs. Sarah G. Crosby, Mrs. Julia Russell Walcott, Mr. H. T. Wentworth, Mrs. Joseph French Johnson, Mrs. S. A. K. Robinson, Miss Florence Ben-Oliel, Mr. Henry B. Hinckley, Dr. John B. Huber, Dr. John S. Hitchcock, Dr. Elmer H. Copeland, and the librarians of Northampton, Springfield, and Worcester, Massachusetts.

To my wife, Gertrude Wilson Powell, I am under the deepest obligation for many aids which she alone could give. To the editorial skill of my nephew, Harold Ayres Powell, I owe much for a searching criticism of the manuscript. To Dr. Talcott Williams I am grateful, as often in the past, for the use of his comprehensive collection of magazine articles 
and newspaper clippings which cover practically every subject of human interest, and can nowhere be duplicated.

Christian Scientists will say as usual that the truths of Christian Science are self-authenticating, and that another critic has, in undertaking to set forth the case, missed the essential point. But others will, I trust, believe that I have brought to one of the most elusive problems of the time a truth-seeking spirit, and that whether all my conclusions stand or not, the variety of quotation from Christian Science writings and the definiteness and comprehensiveness of the facts presented will convince people that it is perilous to commit themselves to this crude faith, which is repudiated with indignation by historic Christianity and with contempt by science, without a clearer understanding than is common of its insecure foundations and its inevitable implications.

\section{P. P.}

ST. JoHN's RECTORY,

NoRthampton, MASS.

August 20, 1907. 



\section{O N T E N T S}

CHAPTER I

PAGES

CHRISTIAN SCIENCE AND HISTORIC CHRISTIANITY

A Strained Relationship-The Cause-Aim of Christian Science-Its Criticism of the Churches-Mrs. Eddy's Purpose-Conscientious Proselyting-The Virtues of the Scientists - Weakness of Christian Churches - The Danger Point.

\section{CHAPTER II}

\section{SCIENCE AND HEALTH}

Source of its Authority - Takes Precedence of the Bible-Exorbitant Selling Price-Its Healing PowerRelationship to New Thought Literature-Faults of Style - Value as a Commentary on the Bible-Fantastic Exegesis-Element of Peril-How it Differs from the Bible-The House upon the Sand. . • • • 12-27

\section{CHAPTER III}

\section{THE SOURCE OF ITS IDEAS}

Modern Claim of their Originality-The Conflict with the Author's Earlier Words-The Quimby PanegyricsTeaching Quimbyism - Cooling Gratitude - Absolute Disavowals-Mesmeric Explanations-Crux of the Situation-1862 versus 1888-Quimby's Scrap-book-Dr. Evans's Testimony-Incapacity of Mrs. Eddy's Modern Witnesses-The Deadly Parallel. 


\section{CHAPTER IV}

\section{THE FOUNDER OF THE FAITH}

The World when she was Born-Childhood-Environment and Education-First Marriage in 1843-Widowhood and Invalidism-Second Marriage in 1853-Visit in 1862 to Quimby - His Healing System-Mrs. Eddy's Great Mistake-The " Final Revelation" in 1866-Separation from her Second Husband and Divorce-Professional Visiting-Partnership in Lynn with Richard Kennedy in 1870-Established as a Healer-Relationship with D. H. Spofford-The Docile Mr. Eddy-Third Marriage-Christian Science Organised in 1875-Removed in 1881 to Boston-Court and Cabinet-College and Church-To Concord in 1889-Christian Science To-day -An Astonishing Autocrat-The Manual-The Modern Mona Lisa-Her Virtues and her Faults. . .

\section{CHAPTER V}

\section{THE PHILOSOPHY}

A Phase of Idealism-Mrs. Eddy Makes a Revelation of it-The Battle Cry of Christian Science-The Question of Reality-Christian Science neither Christian nor Scientific-The Practical Objection - Difficulties of Apologists-Soul Senses-Mrs. Eddy's IsolationAn Unanswerable Criticism-No Room for Evolution -A Grave Indictment-Timely Illustrations of its Philosophical Anarchy.

\section{CHAPTER VJ.}

\section{THE RELIGION AND THEOLOGY}

God All-in-all-Principle not Personality - From Pantheism into Dualism - The Trinity - Christian Science is the Holy Spirit-The Incarnation an Exaggerated Nestorianism-Deifying Mrs. Eddy-Prayer Declaration not Petition-Abandoning the Sacraments - Substitution of a Breakfast for the Lord's SupperEvil no Real Existence-The Absurd Obsession of Animal Magnetism. 


\section{Contents}

\section{CHAPTER VII}

PAGES

\section{CHRISTIAN SCIENCE HEALING}

The Supreme Test of Christian Science-Mrs. Eddy's Claim that Christian Science Cures All Diseases-IIer Followers' Attitude-Venturesome Experiments-Concessions to Public Opinion-Inadequate Diagnoses-All Tests Declined -Mrs. Eddy's Attack upon the Doctors -Reply of Medicine and Surgery-Healing by Understanding of the Christian Science Theory-Practical Illustrations - Chemicalisation - Jesus' Way - Mental Healing through the Centuries-Pseudo-Scientific and True Scientific Mental Healing-Principle Common to Both-The Possibilities and Limitations of Suggestion -Christian Science Admits no Limitations-Consequent Need of State Regulation-The Duty to the Truth.

\section{CBAPTER VIII}

\section{MARRIAGE AND THE FAMILY}

The Gravest Defect-Christian Science Ascetic-Mrs. Eddy's Testimony Prompted by her Personal Experience -Denies the Sacramental Use of Matter-Misinterprets Jesus' Words-Teaches Possibility of Race Perpetuation without Marriage-Some Explanations which do not Explain-Simultaneous Contradictions - The Testimony of the Manual and the Lesson QuarterlyPublic Opinion Making Ready for a Final Judgment -The Alternative-Duty of the Hour.

Notes Index 



\section{BIBLIOGRAPHY}

THIS bibliography does not profess to be complete. It includes in fact only those books and other writings which have proved useful in the preparation of this volume. The current literature on Christian Science is too abundant for mention of more than the most significant magazine articles. The arrangement is made with respect to the special needs of those who may desire to read systematically in explanation, in commendation, or in criticism of the movement.

\section{BOOKS BY MRS. EDDY}

Science and Health with Key to the Scriptures. Boston, editions of 1875, 1881,1883, 1888, 1898, 1905, 1906. Miscellaneous Writings. Boston, 1902.

Retrospection and Introspection. Boston, 1900.

Pulpit and Press. Boston, 1905.

No and Yes. Boston, 1906.

Rudimental Divine Science. Boston, 1906.

Christian Science versus Pantheism. Boston, 1906.

Unity of Good. Boston, 1906.

Christ and Christmas. Boston, 1906.

Church Manual. Boston, 1906.

\section{PAMPHLETS BY CHRISTIAN SCIENTISTS}

Farlow, Alfred. A Critic Answered.

Fluno, F. J. Christian Science: A Reasonable and $R a$ tional Vifw of all Things.

Hanna, S. J. Christian Science History.

Healing through Christian Science.

Christian Science and Legislation. 
xiv

\section{Bibliography}

HERING, H. S. Christian Science: Humanity's Helper. Kimball, E. A. Christian Science and Legislation.

Norton, CAROL. The Christian Science Church: Its Organisation and Polity.

Robinson, Henry. A Biographical Sketch of Rev. Mary Baker G. Eddy.

Sмiтн, C. P. Christian Science and Legislation.

\section{CURRENT LITERATURE FAVOURABLE TO CHRISTIAN SCIENCE}

Beman, S. S., in The World To-day, June, 1907.

Brisbane, ARThUR, in The Cosmopolitan, August, 1907.

Burnham, Clara Louise, in The World To-day, February, 1907.

DUNMORE, EARL OF, in The Cosmopolitan, March, 1907.

EDDY, MrS., in The Independent, Nov. 22, 1906.

EwING, WM. G., in Success, June, 1907.

FARLOW, Alfred, in Government, May, 1907.

Flower, B. O., in The Arena, January, 1907.

Johnston, W. A., in The Broadway Magazine, May, 1907.

Kimball, E. A., in The Cosmopolitan, May, 1907.

Klein, Charles, in The Cosmopolitan, January, 1907. in The Arena, May, 1907.

McCracken, W. D., in The Arena, May, 1907.

Mattox, W. S., in The American Queen, May, 1907.

Mims, Sue H., in Success, May, 1907.

Mosley, J. R., in The Cosmopolitan, July, 1907.

1907.

WILBUR, SibYL, in Human Life, serial beginning January, 1907.

Willis, John B., in The Arena, July.

Yates, Katherine M., in The American Queen, March.

The list of daily papers will not be given.

\section{BOOKS OF CRITICISM OR APPRAISAL}

BuCKLey, J. M., Christian Science and Other Superstitions. New York, 1902. 


\section{Bibliography}

BURrell, J. D., A New Appraisal of Christian Science. New York, 1906.

Casson, H. N., The Crime of Credulity. New York, 1901. Clark, GoRdon, The Church of Saint Bunco. New York, 1901.

Clemens, S. L. (Mark Twain), Christian Science. New York, 1907.

Coe, George A., The Spiritual Life, Ch. IV. New York, 1900.

Cushman, H. E., The Truth in Christian Science. Boston, 1902.

Dresser, A. G., The Philosophy of P. P. Quimby. Boston, 1895.

Dresser, H. W., Health and the Inner Life. New York, 1906.

New York, 1899.

Dresser, Julius A., The True History of Mental Science. New York, 1899.

FARNSWORTh, Edward C., in The Arena, July.

GodDard, H. H., The Effects of Mind on Body, as Evidenced by Faith Cures. American Journal of Psychology, volume $\mathrm{x}, 1899$.

Hutchinson, Oliver W., Christian Science. Leominster, Mass., 1906.

James, William, The Varieties of Religious Experience, Chs. IV and V, New York, 1902.

Micou, R. W., Outline Notes on Fundamental Theology and Christian Apologetics. Alexandria, Va., 1902.

Muldoon, W. H., Christian Science Claims Un-scientific and Un-Christian Brooklyn Eagle Library, 51. March, 1901.

Newton, R. Heber, Christian Science. New York, 1898. Oughton, C. M., Crazes, Credulities, and Christian Science, Chicago, 1901.

Parmelee, Mary Platt, Christian Science. New York, 1904.

Patterson, C. B., The Will to be Well. New York, 1907. 
Peabody, F. W., Complete Exposure of Eddyism or Christian Science. Boston, 1907.

Powell, L. P., The Anarchy of Christian Science. Northampton, Mass., 1906.

Searchlights on Christian Science. New York, 1899.

Shinn, G. W., Some Modern Substitutes for Christianity.

New York, 1896.

SNyDER, JoHn, A Little Journey in Christian Science. Boston, 1907.

Sturge, M. CARta, The Truth and Error of Christian Science. New York, 1903.

Wood, Henry, The New Thought Simplified. Boston, 1903.

Wright, Livingston, How Rev. Wiggin Rewrote Mrs. Eddy's Book. Reprinted from the New York Worla, 1906.

\section{OTHER WRITINGS USED OR CITED}

Barker, Lewellys F., The Nervous System. New York, 1899.

Bernheim, Le Dr., De la Suggestion. Paris, 1888. Bramwell, J. Milne, Hypnotism, its History, Practice, and Theory. London, 1903.

Campbell, R. J., The New Theology. New York, 1907. CASE, C. D., The Masculine in Religion. Philadelphia, 1907.

Dresser, H. W., The Facts of the Case. The Arena, May, 1899.

Dubois, Paul, The Psychic Treatment of Nervous Disorders. New York, 1906. ,The Influence of the Mind on the Body. New York, 1906.

Evans, W. F., Mental Medicine. Boston, 1872 and 1874. FARRAR, F. W., The Bible: Its Meaning and Supremacy. New York, 1897.

Frothingham, O. B., Transcendentalism in New England. New York, 1876.

Hopkins, H. R., The Prognosis in Eddyism, in American Medical Quarterly, January, 1900. 


\section{Bibliography}

Hudson, T. J., The Law of Mental Medicine.

Huxley, T. H., on The Miraculous, in The Nineteenth Century, March, 1899. Chicago, 1903.

Keen, W. W., Surgery, in The Progress of the Century. New York, 1901.

LANe-Poole, Stanley, The Speeches and Table-Talk of the Prophet Mohammed. London, 1882.

Leonard, W. J., Warren Felt Evans, in Practical Ideals, 1905-6.

LODGe, SIR OLIVER, The Substance of Faith Allied with Science. New York, 1907.

Milmine, Georgine, Mary Baler G. Eddy. McClure's Magazine, serial beginning January, 1907.

Moll, Albert, Hypnotism. New York, 1894.

More, Paul Elmer, The Great Refusal. Boston and New York, 1894.

Musser, JoHN H. A Practical Treatise on Medical Diagnosis. Philadelphia, 1900.

Myers, F. W. H., Human Personality, 2 vols. New York, 1903.

Osler, William, The Principles and Practice of Medicine.

New York, 1892.

, Medicine in The Progress of the Century. New York, 1901.

Quimby, Geonge A., Phineas Parkhurst Quimby, in The New England Magazine, March, 1888.

Richardson, T. H., Race Suicide and Christian Science, in The Canadian Journal of Medicine and Surgery. Toronto, October, 1906.

Schofield, A. T., A Study of Faith Healing. New York.

Nerves in Disorder, New York, 1903.

Seaman, Major L. L., on the Japanese Army Medical Service, in Review of Reviews, Nov. 1905.

The Spectator, Feb. 16 and 23, 1907, The Power of Suggestion.

Suzuki, S., Sanitation of the Japanese Navy, in Review of Reviews, Nov., 190 J. 
TAYlor, J. Madison, Drugs and their Abuses, in Popular Science Monthly, May: 1907.

Thomson, W. H., Brain and Personality. New York, 1907.

TuCKey, C. LLOYD, Treatment by Hypnotism and Suggestion. New York, 1907.

Ward, Mrs. Humphrey, The History of David Grieve. New York, 1892.

Wood, IRving F., The Spirit of God in Biblical Literature. New York, 1904.

WoodBury, J. C., The Book and the Woman, in The Arena, May, 1899.

ZeChandelaer, DR., Suggestion, in The Hollandsche Revue, 1907.

Zola, Emile, Lourdes. London, 1903.

To this list should be added the collection of newspaper clippings and magazine articles of Dr. Talcott Williams of Philadelphia, to which reference is made in the Preface. 
CHRISTIAN SCIENCE 



\section{CHRISTIAN SCIENCE}

\section{CHAPTER I}

CHRISTIAN SCIENCE AND HISTORIC CHRISTIANITY

A Strained Relationship-The Cause-Aim of Christian Science-Its Criticism of the Churches-Mrs. Eddy's Purpose-Unconscious Proselyting-The Virtues of the Scientists-Weakness of Christian ChurchesThe Danger Point.

I $\mathrm{F}$ there is to-day a strained relationship be1 tween historic Christianity and Christian Science, the fault chiefly, in the nature of the case, is with Christian Science. The facts in evidence are incontestable.

Christian Science has passed through no such persecution as the early Church experienced. While now and then some minister has raised his voice or pen, he has always spoken for himself alone, and not always even then in criticism severed from appreciation. 
Far from any disposition to drive out the members of their flock turned Christian Scientists, most ministers have, if I may trust my observation and inquiry, tried by kindly toleration and by friendly words to keep them in the fold. When, nevertheless, they would go out, many ministers have watched them go more in sorrow than in bitterness.

Even a careless reader of Mrs. Eddy's books is obliged to see that Mrs. Eddy came not, like Jesus, to fulfil but to destroy. She was prompt in breaking with the past. The knowledge she had gleaned from school books vanished, she remarks, when she discovered Christian Science. ${ }^{1}$ Between Christ and her, all along the intervening centuries, she hints, no thinker has appeared, and she quietly observes, "The time for thinkers has come. Truth independent of doctrines and timehonoured systems, knocks at the portal of humanity." ${ }_{2}$

Christian Science was not the culmination of a movement. "I have found nothing," she says, "in ancient or modern systems on which to found my own." ${ }^{3}$ It was a revelation. No one had made ready for it. No one could. It

${ }^{1}$ Here and elsewhere the numerals in the text refer to notes at the end of the volume. 


\section{And Historic Christianity}

flashed upon her as soon as she was ready to receive it, ${ }^{4}$ and when it did it was "higher, clearer, and more permanent" than His revelation was to Jesus. ${ }^{5}$

Though there are signs of late that some of her representatives do not sharply discriminate between a revelation and an evolution, Mrs. Eddy's course in this regard has been steadily consistent. She withdrew from the church of her upbringing. She founded a church of her own. She gave to it rules and by-laws "impelled by a power not her own." ${ }^{6}$ She claims for her text-book, which containsas she states-the revelation, a place of equal importance with the Bible in the public services of her church. She calls her book "God's Book" and the "Book of Books." ? She contends that it is as truly authorised by Christ as is the Bible. ${ }^{8}$

A quarter of a century has passed since she began to preach in the "Mother Church in Boston," and nowhere all along the years, if her books are a criterion, has she shown any disposition to affiliate with those who do not share her point of view and who yet believe that they are Christians. In spite of Mrs. Eddy's protest in The Independent of Nov. 22 , 1906, that she "loves the prosperity of 
Zion, be it promoted by Catholic, by Protestant, or by Christian Science," there is no mistaking what lies back of words like these, written as long ago as 1890:

Christian Science is the pure evangelic truth. It accords with the trend and tenor of Christ's teaching and example, while it demonstrates the power of Christ as taught in the four gospels. Truth, casting out evils and healing the sick; Love fulfilling the law, and keeping man unspotted from the world-these practical manifestations of Christianity constitute the only evangelism, and they need no creed. ${ }^{9}$ Outside of this science all is unstable error. ${ }^{10}$

She calls the faith of others blind belief resting on the evidences of the senses rather than on the teaching and practice of Jesus, or the world of spirit. ${ }^{11}$ She hints that her sense, whatever it may be, is a higher sense than yours or mine, and speaks outright about our ignorance. ${ }^{12}$ She says that " sin makes deadly thrusts at the Christian Scientist, as naturalism and creed are summoned to give place to higher law." She gives twelve pages, above her average in clearness, in the late editions of Science and Health to the identification of modern Christians with the ancient Pharisees. ${ }^{13}$ 


\section{And Historic Christianity}

Men may differ about even the essentials of Christian faith and yet wish each other well so long as they believe in one another's honesty of purpose. But how can there be the entente cordiale between historic Christianity and Christian Science with Mrs. Eddy falling into what comes close to personal abuse?

As in Jesus' time, so to-day, tyranny and pride need to be whipped out of the temple, and humility and divine science welcomed in. The strong cords of scientific demonstration as twisted and wielded by Jesus are still needed, to purge the temples of their worldly policy, and make them meet dwelling places for the Most High. ${ }^{14}$

As Charles Francis Adams reminded Lord Russell at a memorable moment in our country's history, this sort of thing is war, and no talk about love in the abstract, no injunction to " do good unto your enemies when the opportunity comes," 15 no protestation that Mrs. Eddy loves the orthodox church, can make up for the lack of love displayed through many of her writings. It is war. Mrs. Eddy pictures it in her parody on The Charge of the Light Brigade:

"Traitors to right of them,

M. D.'s to left of them,

Priestcraft in front of them,

Volleyed and thundered." 16 
It is war. But as Mrs. Eddy, more accurate than she designed, describes it, war of her own making on those who have gone out from her, on doctors, and on clergymen,all of whom she pictures in her doggerel as in an attitude, not of offence, but of vigorous self-defence.

Be not deceived. Mrs. Eddy means to drive historic Christianity out of people's minds and to put her faith in place of it. "We can not fill vessels already full. They must first be emptied," ${ }^{17}$ she remarks. Before she published her text-book in 1875, she was making it obligatory on her followers to break with their past, ${ }^{18}$ and to-day the conversion of a man or woman to Christian Science invariably detaches them, in thought at least, from the church of their first love and leads to their affiliation, actual if not always nominal at first, with the band of the like-minded. For a Christian Scientist, old things are passed away, all things are become new.

Everywhere, the Christian Science organisation is made up, it would seem, of those who have come out of Christian churches and who keep out of touch with other Christians, who interpret the embarrassment their own aloofness causes as distraint, charge honest in- 


\section{And Historic Christianity}

quiry to unfriendliness, claim all criticism to be persecution, and serve year in, year out, as magnets, not to draw the heathen far or near, but to draw the discontented and the illinformed from their proper church allegiance. $^{19}$

Nistaking incoherence for illumination, they put into the minds of those who have perhaps no philosophy of life, a philosophy so difficult to understand that when an inquirer in all honesty both fails to understand and refuses to accept on trust, his intelligence is questioned or his sincerity denied. Mistaking pseudo-scientific terminology for scientific truth, they give to people who may be informed in everything but science, conceptions which would crowd out of even the most spacious mind every fact that science has discovered and every generalisation that science has established. Mistaking optimistic vagueness for Christian revelation, they allure from their allegiance the generous, the high-minded, and the overtrustful, who appearing to find in Christian Science relief from certain ills they thought incurable, straightway forget that a little knowledge is a dangerous thing and hasten on to the conclusion that Christian Science must be true in all respects because it may be true in one. 
No one doubts the good intentions of the Christian Scientists. Some of the purest souls alive to-day are Christian Scientists. They have done much good. Allowing all you will for exaggeration, there can be no denying that Christian Scientists have helped the sick, reformed the drunkard, reclaimed the prodigal, brought surcease to many a sorrow and anxiety, tempered life's asperities, furnished a philosophy for every-day existence where there was none before, filled souls with what Charles Klein has called "happiness far beyond my wildest dreams."

To an age grown weary and impatient of ecclesiasticism and machinery, Christian Scientists have brought something of the warmth and glow, the freshness and the spontaneity, the poise and the sincerity, the gladness and the other worldliness which suffused the Apostolic age and made it all alive with spiritual power..$^{20}$

The early Christians lived above life's fret and turmoil. They knew the peace which passeth understanding. They endured as seeing Him who is invisible. They lived for Jesus Christ and Him alone. Knit together " in one holy bond of truth and peace, of faith and charity," they went out to win the world to Christ. 


\section{And Historic Christianity}

Christians to-day in many places seem to have lost the Apostolic spirit. 'They appear sometimes to believe with their heads but not with their hearts. There is much in Christendom now to recall the situation in Rome when " every man had two religions; the one he professed and the other he believed." 21 Christian work to-day is far too often automatic. Christians are too prone to give everything but themselves to the cause they represent. Forgetting that the good fight of faith is never won by hirelings, they are apt to send substitutes in their stead and to repair to the golf links. Guilds and societies are frequent and inadequate representatives of " one holy bond of truth and peace, of faith and charity."

While this is distinctively a church-building age, it is not so clearly a church-going age. Men are so small a proportion of the average congregation that the faith is often feminised. ${ }^{22}$ The Church's loss of moral leadership is everywhere admitted. The Priest and Levite, as President Eliot said the other day, too often pass by the great evils of the age. Church papers now are in the stage of explanation. The great preachers of the new redemption of society are found in the White House, the cabinet, and the editorial room, oftener than the pulpit. Far from standing together and 
together going out, as early Christians did, to conquer all for Christ, the Christian Church at large is broken up into conflicting sects, and the individual church in many a place is divided into sets distrustful of one another and insistent on those undemocratic class distinctions which are the bane of Church and State alike and which make the Church, though not the Christ, a hissing and a by-word everywhere.

And God, unless the signs belie Him, is growing weary of it all. He is saying in these days to many a church that will not hear his voice: "Bring me no more vain oblations. . . Your appointed feasts my soul hateth; they are a trouble unto me; I am weary to bear them!" "What doth the Lord require of thee but to do justly and to love mercy, and to walk humbly with thy God?" 23 There must be a return all along the line to Apostolic simplicity, Apostolic spontaneity, Apostolic love, Apostolic joy, and Apostolic peace. And Christian Science, whatever be its limitations, seems to some to blaze a way.

Christian Science has its faults, but Christian Scientists, whatever the demerits of their system, have many virtues to their credit. "They are sincere and filled with that moral enthusiasm that is a potent motor power in all 
great religious or ethical movements in their early days." 24 They believe in spiritual things, and they are as bold in uttering their belief as were the early Christians. There is never the apologetic note for which one instinctively listens in the talk of many Christians in these days. They are protests in the flesh against the worldliness and the ecclesiasticism which afflict the Church, and the materialism and lust which threaten the foundations of the social order. They furnish everywhere proof positive and peace-bringing, that where there is a will there is a way to live the spirit's life against all odds.

And yet in spite of all the virtues which I find in Christian Scientists and more readily admit because I count them rather the product of historic Christianity than of Christian Science, I see in Christian Science defects which in time will either relegate it to the limbo of exploded heresies or which, should it possibly become the universal faith-a manifest improbability-will take from the world all humanity has learned in ages past, will write falsehood across the brow of philosophy, science, and religion, and will give us in the place of what we have, the inheritance of the centuries, some sort of anarchy. 


\section{CHAPTER II}

SCIENCE AND HEALTH

Source of its Authority-Takes Precedence of the BibleExorbitant Selling Price-Its Healing Power-Relationship to New Thought Literature-Faults of Style-Value as a Commentary on Bible-Fantastic Exegesis-Element of Peril-How it Differs From the Bible-The House Upon the Sand.

WHILE there is an abundant literature on Christian Science, there is but one authentic source of information. That is Mrs. Eddy's monumental book, Science and Health, first published in 1875 , and now past its 440th edition. It is a portly volume of some seven hundred pages and more than two hundred thousand words. But large as is the book, its claim for authority is larger. The author gravely writes that Science and Health is "the voice of Truth to this age, and contains the whole of Christian Science." ${ }^{1}$ The book is to be read at every Christian Science service in explanation of the Bible, and is, Mrs. Eddy says, through her official representatives, as 
" uncontaminated and unfettered by human hypotheses" as is the Bible, and as surely "authorised by Christ." 2

But this surprising claim is modesty itself compared with the larger clain which Mrs. Eddy makes in her autobiography that Science and Health occupies a vantage ground which the Bible does not share. These are her own words: "'The Scripture gave no direct interpretation of the Scientific basis for demonstrating the spiritual Principle of healing, until our Heavenly Father saw fit, through the key to the Scriptures, in Science and Health, to unlock 'this mystery of Godliness.' " ${ }_{3}$ And then, as though to allay the dismay such words are apt to bring to those who read them first, she writes in 1901: "I should blush to write of Science and Health, with Key to the Scriptures, as I have, were it of human origin, and I apart from God, its author; but as I was only a scribe echoing the harmonies of heaven, I can not be supermodest of the Christian Science text-book." ${ }_{4}$

After this, one is not surprised to find the Bible yielding first place in Christian Science worship to the Christian Science text-book. It seems fitting in the light of Mrs. Eddy's estimate of the relative importance of the 
Bible and her book that the Second Reader, not the First, should read aloud the Scripture texts while to the First Reader falls the more important task of reading the passages from Science and Health which are expected to explain in full the meaning of the Bible words. ${ }^{5}$

But to the practical mind far more significant is the amazing difference in the selling price of the two books. The Bible with its million words can be bought by any one for fifteen cents. ${ }^{6}$ Science and Health, not onefourth as large, sells in its least expensive form, for \$3.18. Whether rich or poor, you must pay for Science and Health, allowing for the difference in size of the two books, eighty times as much as you may pay for your Bible. The Bible is sold at cost in the cheaper editions. Science and Health in its cheapest form yields a profit to its author amounting probably to several hundred per cent.

In quantities of one hundred thousand copies Science and Health can, as I am informed, be reproduced at a cost of from thirty to forty cents a copy. Mark Twain, with his life-long experience as both an author and a publisher, thinks that the cost would be much smaller in the case of a book like Science and Health " whose market is so sure and so great that you 
can give a printer a standing order for thirty or forty or fifty thousand copies a year," which will enable him to work at the contract " whenever there is a slack time in his press-room and bindery." " In confirmation of Mark Twain's estimate, an easy calculation will clearly indicate that the weekly output of Science and Health is now about a thousand copies and a new edition is run off the press every two or three weeks.

The Publication Committee, after disclaiming all specific knowledge of the facts, says that the Christian Science text-book is "printed in small quantities and with constant changes," that there is a profit to the publisher and the retailer to be taken into account, and that the expense of transportation is paid by the publisher in lots of one dozen or more. ${ }^{8}$

But such an explanation is not adequate. The cost of making the plates is the same for one copy as for one hundred thousand copies. The changes made from time to time cannot be considerable in a book of which there have been in ten years almost three hundred new issues, an arerage of almost three a month. ${ }^{9}$ It is also of significance that in the preparation of the Bible lessons for the present quarter, not the 440th edition, but the 379th was used, 
and "most of the references can be found," says the note for students of the lessons, "in the previous editions" back as far as the 226 th, which appeared some years ago. ${ }^{10}$

With full allowance for proper compensation to the publisher, the retailer, and the transportation companies, there will still be for the author a profit of several hundred per cent. Mrs. Eddy has actually acknowledged in the case of Eddy versus Frye et al that she has an estate amounting to almost a million dollars, ${ }^{11}$ most of which has doubtless accumulated from the sale of Science and Health, of which every Christian Scientist is obliged to circulate and sell as many copies as possible on pain of losing "his membership in the church." 12

Again, Mrs. Eddy claims for her book what has never in all the Christian centuries been claimed for the Bible, that the mere reading of it "heals sickness constantly." The Earl of Dunmore, who died August 27, testifies that his wife was "literally snatched from the jaws of death through reading the Christian Science text-book." 'The palsied arm of another was cured by reading the single sentence "All is Mind." ${ }^{13}$ And some have claimed that one sentence fully understood will cure disease of 
any sort. The spiritual atmosphere which the book generates, wherever and whenever it is read, is too rarefied to nourish long the false view that we are sick; therefore we get well.

Many of the thoughts found in Science and Health abound in the Christian literature of this and of other times. Much of it is familiar to those who read the New Thought books of Henry Wood and Charles Brodie Patterson. ${ }^{14}$ In them as well as in the Christian Science text-book there is insistence on the unity of all life and of all intelligence gathered up into the thought of God as "All in all." But as to matter, sin, and pain there is a constant and irreconcilable difference. The New Thought does not invalidate the evidence of the senses. The New Thought does not dodge the realities of life. The New Thought admits the actual existence of matter, sin, and pain, but teaches us to rise above them on the spirit's wings. Christian Science dismisses them as vain imaginings of mortal mind and is put to such shrift to deny their existence as makes Science and Health sometimes read, says Dr. Elwood Worcester, "like the writing of a philosopher suffering from acute softening of the brain."

The difficulty is not merely with the style, which though often marred by absurdity, tur- 
gidity, and faulty diction, possesses a certain lofty distinctiveness, a certain sonorous authoritativeness, which a book that claims to be a revelation ought to have to command the interest of the undiscriminating. The difficulty is also with the arrangement of the work. There is a woful want of sequence both in thought and word. The reader can begin anywhere and stop anywhere without serious loss or gain. Mrs. Eddy in one section states that certain of her sentences read backward mean as much as when read forward, and many not of her persuasion will readily agree with her.

No matter what editions you may chance to be comparing, there is an unexpected instability of arrangement in a book which the author claims is of the nature of "final revelation." Mrs. Eddy is not content to let the sequence remain permanent. Of four editions dated, respectively, 1881, 1888, 1898, and 1906, the chapter which comes first in the first and second of the four editions comes fifth in the third and sixth in the fourth. The second chapter in the first and second editions is third and eighth respectively in the third and fourth. The third chapter in the first edition appears as the fifth in the second, the second in the 
third, and the seventh in the fourth. Chapter IV in the first edition is Chapter XII in the second and XIV in the third and fourth editions. Chapter $\mathbf{V}$ in the first is $\mathbf{I X}$ in the second, XII in the third and fourth. And the variation lasts throughout.

Lucidity is an honest test to apply to any modern Anglo-Saxon book. Those who think clearly and write clearly can state the truth to-day in terms the average mind can understand. And when normal people find men as high above the average as the Rev. Drs. Lyman Abbot, George A. Gordon, J. M. Buckley, and Elwood Worcester differing among themselves as to the meaning of Science and Health it is not, perhaps, unreasonable to conclude that the responsibility rests not on the reader but on the author of the book.

Mrs. Eddy has undoubtedly improved greatly in her power to express herself on paper, since her literary helper ${ }^{15}$ twenty year's ago testified she was constantly confusing such words as physics and physiology. gnnstic and agnostic, and putting him to his wits' end to save her "from making herself ridiculous and from flatly contradicting herself." But there is still some justification for Mark 
Twain's sweeping judgment that Mrs. Eddy "so lacks in the matter of literary precision that she can seldom put a thought into words that express it lucidly to the reader and leave no doubts in his mind as to whether he has rightly understood or not." ${ }^{16}$

Philosophy is broken up to-day into three camps. In one, matter is regarded as the only reality; in another, mind and matter seem alike substantial; in the third, matter is steadily characterised as but a form of thought. It is in this camp that Mrs. Eddy can be found, but she has a special tent. Her philosophy is a "crude unintelligent form of idealistic pantheism." ${ }^{17}$ Her purpose is to superimpose it on organic Christianity by making Science and Health the one authoritative commentary on the Bible.

To the most audacious task any commentator ever undertook Mrs. Eddy brings nothing usually considered necessary to Biblical exegesis. She says in her autobiography that she learned some Greek and Hebrew when she was a girl. But she also says that all her childhood learning "vanished like a dream" after her discovery of Christian Science. ${ }^{18}$

If she has any quality except persistence required in the scholar whose business it is to 
find out what the Bible means, no matter what philosophy it may support, Mrs. Eddy has succeeded all these years in hiding it from even the most searching student of her book. If she knows anything of the real nature of the problems on which Biblical experts are brooding in these days she nowhere gives a sign of it. ${ }^{19}$ She indicated in a letter of last April her intention to take up the higher criticism, but at eighty-six a mind is too well-seasoned to be likely to habituate itself to a radically different point of view.

The fact is that she distrusts all modern learning, and with her approval the Mother Church in Boston chose for its new president, June 11, 1907, a man who put himself on record thus in his acceptance of the office: "In an age of so-called higher criticism, wherein the fundamental truths of the Bible are openly assailed and cast aside as impractical and visionary, it remains to them [Christian Scientists] to preserve for future generations the very integrity of the Scriptures." 20

Her exegesis of specific words is but the reading into them of meaning necessary to support her strange philosophy. To oblige a commentator so ambitious one would believe, if it were possible, that Science and Health 
contains, as its author earnestly assures us, " the metaphysical interpretation of Bible terms-giving their spiritual sense, which is also their original meaning." But how can it be possible with interpretations offered us as fanciful as these? ${ }^{21}$

Adam "represents the false supposition" that "the Infinite enters the finite."

$A r k$ means " the understanding of spirit, destroying belief in matter."

Baptism is "submergence in Truth."

Children are "counterfeits of creation, whose better originals are God's thoughts."

Dan is " animal magnetism : so-called mortal mind controlling mortal mind."

Death: "Any material evidence of death is false."

Mortal Mind: "Nothing, claiming to be something."

Mother: "God, divine and eternal Principle, Life, Truth, and Love."

New Jerusalem: "Divine Science."

Noah: "Knowledge of the nothingness of material things, and the immortality of all that is spiritual."

Will: "The motive-power of error."

No less fanciful is Mrs. Eddy in the interpretation of specific texts. ${ }^{22} \mathrm{Her}$ practice is, as in the exegesis of words, to give every text the meaning it should have to illustrate her philosophy. 
"Thy kingdom come" she thus explains regardless of the tense: "Thy kingdom is within us, Thou art ever present."

"That was the true Light, which lighteth every man that cometh into the world," carries with it the evident non sequitur: "Truth crossquestioning man as to his knowledge of error, finds woman the first to confess her fault."

"The Lord knoweth the way of the righteous, but the way of the ungodly shall perish." When a truth is so self-evident, why need Mrs. Eddy add "Truth has but one reply to all error, to sin, sickness, and death: 'Dust (nothingness) thou art, and unto dust (nothingness) shalt thou return'"?

"I am he that liveth and was dead: and behold I am alive for evermore, Amen; and have the keys of hell and of death." 'The Book of Revelation is difficult at best to understand. Explanations like the following but enhance the difficulty: "Truth should, and does drive error out of all selfhood."

Once at least Mrs. Eddy has ventured to change outright the words of Scripture so as to alter their essential meaning. She sent the following telegraphic greeting to the $\mathrm{Na}$ tional Christian Science Association in session in New York, May 27, 1890: 
"All hail! He hath filled the hungry with good things and the sick he hath not sent empty away.-Mother Mary."

When later brought to account by a distressed disciple for substituting "sick" for "rich" and inserting a "not" where there was none, she showed at first no disposition to correct the error, though she did correct it casually two months later in an organ circulated only among her own flock. ${ }^{23}$

People outside Christian Science will scarcely be inclined to take Science and Health seriously as a commentary on the Bible. And yet the book must not be dismissed too lightly. It is read in comment on the Bible every Sunday at the service, every week day in the home. Christian Scientists are among the few people in the land who read their Bible every day. Theirs is the only organisation in Christendom which commands the Bible to be read in the light of any commentary. Science and Health is therefore coupled with the Bible in the minds of some of the most zealous propagandists of religion in Christendom to-day, and they number many thousands. There are elements of peril in the situation.

And yet it can not be that the Bible is to suffer permanently from the obsession Mrs. 
Eddy's masterpiece has placed upon it. The difference between the two books is fundamental. The Bible is built upon the rock of actual experience. It explains no facts away. It throbs with life lived in the body. It is the story of man's battle with the beast within. Through the pages of the Bible, from Genesis to Revelation, man is ever coming "from Edom, with dyed garments from Bozrah." The Bible is stained through with red blood. Real blows are given. Real tears are shed. Real shouts of victory ring out on the air. Live men and women tell us their heart secrets and we listen as though we saw them face to face. The Bible finds every one because it is intensely biographical. "Sunrise and sunset, birth and death, promise and fulfilment, the whole drama of Humanity are all in this book!" 24

Science and Health is built upon the sand of metaphysics, and on nothing else. It is the most successful effort which the modern world has seen to make popular a philosophical abstraction. It is, to be sure, biography, but the biography of a single soul, and that a soul which has not entered deeply into life. If the author of Science and Health has ever yielded herself in a self-forgetful outpour of 
affection to any human soul, there is no trace of such experience in her book. Once at least she has reproved a follower for expecting to receive from her a love individualised. The love she has for man she gives to man as an abstract composite. No one would think of calling her what Henry Drummond once called Dwight L. Moody, "a big human." There are no heart throbs in her book. There is nothing human in it.

"My soul is athirst for God; yea, for the living God," the psalmist says. Mrs. Eddy mildly hints that "the human capacities are enlarged and perfected, in proportion as humanity gains the true conception of man and God." 25

"The effectual fervent prayer of a righteous man availeth much," St. James informs us. Mrs. Eddy enters a demurrer: "This common custom of praying for the recovery of the sick, finds help in blind belief; whereas help should come from the enlightened understanding." 26

Completely conscious of the terrible reality of $\sin$ in his own heart, St. Paul breaks out: " $\mathrm{O}$ wretched man that $\mathrm{I}$ am! Who shall deliver me from the body of this death?" Mrs. Eddy would deftly pluck away anxiety with 
the impersonal remark, "If sin were understood as nothingness it would disappear." $2 \tau$

"These things I command you, that ye love one another," said the Master to His friends the night before the crucifixion. "Personal love is little better than personal hate," ${ }^{23}$ is Mrs. Eddy's contribution to the subject.

To those to whom death seems something more heart-breaking than "the mortal dream" ${ }^{29}$ which Mrs. Eddy calls it, the last book in the Bible brings the comforting assurance that "God shall wipe away all tears from their eyes." Mrs. Eddy cheers them with the cold comfort that "there is no cause for grief." 30

The Bible is built upon the human heart. That is the reason why when in ages past " the rain descended, and the floods came, and the winds blew, and beat upon that house, it fell not "; "it was founded upon a rock."

Science and Health is built upon the sand of metaphysics. That is the reason why, in spite of Mark Twain's generous prediction, another century may look back on this strange delusion and remark: "The rain descended, and the floods came, and the winds blew, and beat upon that house; and it fell: and great was the fall of it." 


\section{CHAPTER III}

\section{THE SOURCE OF ITS IDEAS}

Modern Claim of their Originality-The Conflict with the Author's Earlier Words-The Quimby PanegyricsTeaching Quimbyism-Cooling Gratitude-Absolute Disavowals-Mesmeric Explanations-Crux of the Situation-1862 versus 1888-Quimby's Scrap-bookDr. Evans's Testimony-Incapacity of Mrs. Eddy's Modern Witnesses-The Deadly Parallel.

F OR the thoughts expressed in Science and Health Mrs. Eddy disavows indebtedness to any human soul. "No human pen or tongue," she says in 1906, " taught me." " In the year 1866 I discovered the Christ Science ... and named it Christian Science"; and to give her claim Apostolic import she quotes in preface to her words a sentence of St. Paul's: "I neither received it of man, neither was I taught it, but by the revelation of Jesus Christ." 1

Here the Christian Scientist is well content to rest the case. Mrs. Eddy's word suffices. He would take her word against the world. 
Evidence, no matter who may offer it, tending to invalidate her word seems to him, in the premises, "deliberate falsehood." 2 But unhappily for the Christian Scientist he has to reckon with other words, and earlier, from Mrs. Eddy's pen.

Thirteen years before Science and Health appeared, four years before she claims in 1906 to have discovered Christian Science, Mrs. Eddy wrote of a well-known healer, P. F. Quimby, who cured her of an illness:

Now I can dimly see at first, and only as trees walking, the great principle which underlies Dr. Quimby's faith and works; and just in proportion to my right perception of truth is my recovery. This truth which he opposes to the error of giving intelligence to matter and placing pain where it never placed itself, if received understandingly, changes the currents of the system to their normal action; and the mechanism of the body goes undisturbed. That this is a science capable of demonstration becomes clear to the minds of those patients who reason upon the process of their cure. 3

Transported by sheer gratitude she next says of Dr. Quimby, since he "speaks as never man before spake, and heals as never man healed since Christ, is he not identified with 
truth? And is not this the Christ which is in him?" 4

Grateful beyond prose she then proceeds to bathe her healer in bathetic doggerel:

"Mid light of science sits the sage profound, Awing with classics and his starry lore,

Climbing with Venus, chasing Saturn round, Turning his mystic pages o'er and o'er, Till, from empyrean space, his wearied sight Turns to the oasis on which to gaze,

Nore bright than glitters on the brow of night The self-tanght man walking in wisdom's warss. Then paused the captive gaze with peace entwined, And sight was satisfied with thee to dwell;

But not in classics would the book-worm find That law of excellence whence came the spell Potent o'er all,- - the captive to unbind, To heal the sick and faint, the halt and blind." 5

In the months that followed she talked incessantly of Dr. Quimby to her friends, and turned them into patients when she could. Her intimate of those days, Mrs. Crosby, in whose home Mrs. Eddy stayed for several months, and of whom she once wrote Dr. Quimby "Mrs. Crosby is one of the precious few affinities with whom I meet," writes as though there were no doubt of Mrs. Eddy's complete absorption in the views of Dr. Quimby. She adds that even as late as $\mathbf{1 8 7 7}$, 
when she was reporting Mrs. Eddy's lectures, Mrs. Eddy's views were "substantially the same" as the two had learned some fifteen years before at Quimby's feet. ${ }^{6}$ The testimony of Mr. and Mrs. Julius A. Dresser, also student-patients when Mrs. Eddy was, speaks to the same effect, though they note that Mrs. Eddy's subsequent interpretation of the teachings of her master was one-sided. ${ }^{\tau}$ And Quimby's son, then just past his majority, says that "Christian Science would not now exist if Mrs. Eddy had not filched the healing idea from him." $s$

She deluged Dr. Quimby with letters, which she now must wish were not extant, and which are overfull of fulsome acknowledgment of her indebtedness to him for the help he gave her mind as well as for the healing of her body. January 12, 1863, she wrote: "I am to all who see me a living wonder, and a living monument of your power. . . My explanation of your curative principle surprises people, especially those whose minds are all matter." In letters that followed occur such sentences as these: "Who is wise but you?" "Dear Doctor, what could I do without you?" "I am up and about to-day, i. e., by the help of the Lord (Quimby).” “Jesus taught as man 
does not, who then is wise but you?" "Posted at the public marts of this city is this notice,-_Mrs. M. M. Patterson [now Mrs. Eddy] will lecture at the 'Town Hall on P. P. Quimby's Spiritual Science healing disease, as opposed to Deism or Rochester Rapping Spiritualism.'" 9

When Dr. Quimby died, January 16, 1866, the year Mrs. Eddy says she discovered Christian Science without the help of human pen or tongue, she was concerned lest no one should be found strong enough to bend Ulysses' bow. She urges Mr. Dresser, a man of unusual character and ability, to take up the work of Quimby on the score that no one is so well equipped as he to carry on the enterprise. Then she crowns four years of panegyric of her healer and her teacher with an obituary possibly as mellifluous and melodramatic as was ever visited on the memory of any soul by a sentimental and adoring worshipper:

"Did sack-cloth clothe the sun and day grow night, All matter mourn the hour with dewy eyes, When Truth receding from our mortal sight Had paid to error her last sacrifice?

"Can we forget the power that gave us life? Shall we forget the wisdom of its way? 


\section{The Source of its Ideas}

Then ask me not amid this mortal strife-

This keenest pang of animated clay-

"To mourn him less; to mourn him more were just If to his memory 't were a tribute given For every solemn, sacred, earnest trust Delivered to $u s$ ere he rose to heaven.

"Heaven but the happiness of that calm soul, Growing in stature to the throne of God; Rest should reward him who has made $u s$ whole, Seeking though tremblers, where his footsteps trod." 10

In the years that followed Quimby's death in 1866 Mrs. Eddy in season and out was preaching Quimby's ideas and giving him the credit for them all. Those closest to her then are in complete agreement on this point. Dr. A. M. Cushing, who attended Mrs. Eddy professionally in February, 1866, and again in August, 1866, tells me that as her physician he was much embarrassed by her frequent references to Dr. Quimby. ${ }^{11}$ Mrs. Julia Russell Walcott writes me of Mrs. Eddy's continuous study of the notes of Quimby that same year at the Russells' in Lynn and at the Wheelers' in Swampscott. ${ }^{12}$ At the Ellises' in Swampscott she was constantly explaining Quimby's theories of mind and matter. ${ }^{13}$ The spring of $\mathbf{1 8 6 7}$ found her instructing Hiram 
S. Crafts, of East Stoughton, in Quimby's healing system, and later, in Amesbury, she was known as Quimby's pupil. At the Wentworths' in Stoughton, where she stayed for two years, her one consuming interest was Quimbyism, and she was continually emphasising this. Mr. Richard Kennedy, her partner in the healing work from $18 \% 0$ to 1872 , bears tribute to the largeness of the Quimby influence in her life, and Mr. Daniel H. Spofford, who knew her intimately in the years that followed, speaks in the same vein. ${ }^{14}$

But by and by Mrs. Eddy's transports of affection for her teacher cooled. As pupils came beneath her spell, they began to doubt whether Quimby could have meant so much to her as she had thought, and she was not unwilling to revise her earlier impressions in the interest of her growing fame. Her memory of the details of her relationship to Quimby steadily grew more and more defective. Her earlier panegyrics of him faded from her recollection. "Others of his pupils," says Georgine Milmine, " lost themselves in Quimby's philosophy, but Mrs. Glover lost Quimby in herself." ${ }^{15}$ By 1883 she was making bold to qualify the more tenacious memory of even Mrs. Crosby. She tried, with the help of a 


\section{The Source of its Ideas}

lawyer, to induce Mrs. Crosby to make affidavit that when they two were fellow-patients under Quimby more than twenty years before, she "used to take his scribblings and fix them over for him and give him my thoughts and language, which, as I understood it, were far in advance of his." Mrs. Crosby's answer was so prompt and unsatisfying that she has never since had word from Mrs. Eddy. ${ }^{16}$

By this time Mrs. Eddy could bear to write with some aplomb:

We never were a student of Dr. Quimby's. . . We were one of his patients. . . We knew him about twenty years ago, and aimed to help him. We saw he was looking in our direction, and asked him to write his thoughts out. He did so, and then we would take that copy to correct, and sometimes so transform it that he would say it was our composition, which it virtually was.

The next year she was able to speak with something close to patronising nonchalance.

The old gentleman to whom we have referred had some very advanced views on healing, but he was not avowedly religious, neither scholarly. We interchanged thoughts on the subject of healing the sick. I restored some patients of his that he failed to heal, and left in his possession some manuscripts of mine containing corrections of his desultory pennings. ${ }^{17}$ 
Brought to book by some of the letters which she had written earlier to Dr. Quimby in frank acknowledgment of her obligations to him, Mrs. Eddy disavows responsibility by asserting that she wrote these under mesmeric influence.

"Did I write those articles purporting to be mine?" she asks in the Boston Post, March 7, 1883, after the publication of some of the most damaging of all the letters. "I might have written them twenty or thirty years ago, for I was under the mesmeric treatment of Dr. Quimby from 1862 until his death. . . My head was so turned by animal magnetism and will power, under treatment, that I might have written something as hopelessly incorrect as the articles now published in the Dresser pamphlet. I was not healed until after the death of Mr. Quimby; and then healing came as the result of my discovery, in 1866, of the Science of Mind-healing, since named Christian Science." 18

Though her literary helper, Rev. J. H. Wiggin, told her frankly that there was nothing to be said for her new attitude toward Dr. Quimby, and wrote in a personal letter (now in the possession of McClure's Magazine) that "What Mrs. Eddy has, as documents clearly prove, she got from P. P. Quimby of Portland, Me., whom she eulogised after death as the great leader and her special teacher," Mrs. 


\section{The Source of its Ideas}

Eddy has with passing years grown more assertive that she owes no debt to Dr. Quimby, that he in fact got all he knew from her. But even thus she has not steadily adhered to the date, 1866, which she sets in 1906 for the discovery of her system. In 1875 she gives the year as 1864; in 1883 as 1853; and in 1887 she writes, " As long ago as 1844 I was convinced that mortal mind produced all disease and that the various medical systems were in no proper sense scientific." 19

To the Christian Scientist, all this confusion of dates and contradiction of facts presents no problem. Mrs. Eddy's latest word is for him her authentic word. Anything spoken hitherto that does not agree with what she says to-day was spoken under the mesmeric influence of animal magnetism and therefore is superseded.

To the generous-minded, there will at once recur in the consideration of the problem instances in which what seem to be discrepancies of dates might conceivably be stepping-stones in the development of a great system. But unhappily Mrs. Eddy has appeared unwilling, since she came to wider repute, to give to her master credit such as once she gave readily for any share whatever in her preparation 
for an unusual career. Though one would gladly attribute to mental incapacity for exact expression seeming inaccuracies of statement, it is a significant circumstance, as Georgine Milmine hints, ${ }^{20}$ that each date or statement given by Mrs. Eddy appears to have had the purpose either of disavowing all indebtedness to her teacher or of extricating herself from some difficulty of the moment; and if one is seeking for the truth and nothing but the truth, one can but hesitate.

The essential issue is this: What was Quimby's healing method when Mrs. Eddy came in 1862 into his life? Mrs. Eddy says in 1888 that Quimby was "a distinguished mesmerist and that his method was thoroughly physical rather than mental." ${ }^{21}$ But she had described it about 1862 in terms that contradict her words of 1888. Which Mrs. Eddy are we to believe, the Mrs. Eddy of 1888 or 1862? Both cannot be believed.

The P. P. Quimby who, alive, in 1862 furnished Mrs. Eddy the true answer that she gave that year, dead speaks to her confusion now. There lies before me as I write a little worn and faded scrap-book. ${ }^{22}$ It bears on the fly-leaf the name of P. P. Quimby. It was his own book. His wife pasted in it for 
him now and then in the fifties and early sixties newspaper comments on his work. It contains also an important circular prepared with his son's assistance, which Quimby used in the early sixties to describe his healing methods, and of which Mrs. Eddy wrote him, four months before she first met him, "I have entire confidence in your philosophy as read in the circular."

It is interesting to observe that all the comments testify that his method was exactly as described in 1862 by Mrs. Eddy. Two clippings, bearing the date of 1856 , deny that he used mesmerism and picture him as saying that " diseases of the body are caused by a derangement of the mind" and as battling with disease as purely "mental." Another, a year later, from the Bangor Jeffersonian, denies that he employed mesmeric methods and then proceeds to the illuminating statement that the mind can cure as well as cause disease. The Free Press, Lebanon, New Hampshire, December 3, 1860, expresses the conviction that "the foundation of his theory, regarded simply as a belief, is that disease is not selfexistent nor created by God, but that it is purely the invention of man." Yet another, dated 1861, announces that Quimby cures 
even the most desperate cases of disease "on scientific principles, without the use of medicine or any material agency; also without the aid of mesmerism."

A clipping from the Portland Advertiser of February 13, 1862, contains Quimby's own statement: "I deny disease as a truth, but admit it as a deception." The next month, in the same paper, Dr. F. L. Town, assistant surgeon in the United States army, on his own responsibility lifts Quimby out of the class of "spiritualists, clairvoyants, and other charlatans."

Later in the same year I find in the Portland Courier an eloquent denial that Quimby was either a spiritualist or mesmerist, and an unequivocal statement that under Quimby's care patients recovered "in proportion to "their' perception of truth." 'This letter is signed by Mary M. Patterson, earlier Mary M. Glover, and now Mary Baker G. Eddy.

With these facts in mind the reader will probably be more inclined to accept the word of Mrs. Patterson of 1862, confirmed as it is by others competent to speak, than of Mrs. Eddy of 1888 dismissing Quimby merely as a mesmerist, and in 1907 inspiring a defender to proclaim "that P. P. Quimby was a mes- 


\section{The Source of its Ideas}

merist, that he mesmerised her body and hypnotised her thought." 23 But if anything is wanting to enable one to decide between Mrs. Eddy of 1862 and Mrs. Eddy of 1888 and 1907 the following circular, mentioned above and in use from 1860 to 1865, from Quimby's scrap-book, will supply the want.

\section{TO THE SICK.}

DR. P. P. QUIMBY would respectfully announce to the citizens of

and vicinity, that he will be at the where he will attend to those wishing to consult him in regard to their health, and, as his practice is unlike all other medical practices, it is necessary to say that he gives no medicines and makes no outuard applications, but simply sits down by the patients, tells them their feelings, and what they think is their disease. If the patients admit that he tells them their feelings, etc., then this explanation is the cure; and, if he succeeds in correcting their error, he changes the fluid of the system and establishes the truth or health. The Truth is the Cure. This mode of practice applies to all cases. If no explanation is given, no charge is made, for no effect is produced. His opinion without an explanation is useless, for it contains no knowledge, and would be like other medical opinions, worse than none. This error gives rise to all kinds of quackery, not only among regular physicians, but those whose aim is to deceire people by pretending to cure all diseases. The sick are anx- 
ious to get well and they apply to these persons, supposing them to be honest and friendly, whereas they are made to believe they are very sick and something must be done ere it is too late. Five or ten dollars is then paid, for the cure of some disease they never had nor ever would have but for the wrong impressions received from these quacks, or robbers, (as they might be called), for it is the worst kind of robbery, tho' sanctioned by law. Now, if they will only look at the secret of this description, they will find it is for their own selfish objects -to sell their medicines. Herein consists their shrewdness!- to impress patients with a wrong idea, namely-that they have some disease. This makes them nervous and creates in their minds a disease that otherwise would never have been thought of. Wherefore he says to such, never consult a quack; you not only lose your money, but your health.

He gives no opinion, therefore you lose nothing. If patients feel pain they know it, and if he describes their pain he feels it, and in his explanation lies the cure. Patients, of course, have some opinion as to what causes pain-lhe has none, therefore the disagreement lies not in the pain, but in the (ause of the pain. He has the advantage of patients, for it is very easy to convince them that he had no pain before he sat down by them. After this it becomes his duty to prove to them the cause of their trouble. This can only be explained to patients, for which explanation his charge is dollars.

If necessary to see them more than once dollars. This has been his mode of practice for the 
last seventeen years. For the past eight years he has given no medicines nor made any outward applications.

There are many who pretend to practise as he does, but when a person while in "a trance," claims any power from the spirits of the departed, and recommends any kind of medicine to be taken internally or applied externally, beware! believe them not, "for by their fruits ye shall know them."

But besides the Quimby scrap-book there is another confirmation of Mrs. Eddy's estimate of 1862. It is found in a book published in 1872, three years before Science and Health first appeared and the Christian Science organisation was formed, and while Mrs. Eddy was still paying glad tributes to her master. The book bears the title Mental Medicine. Its author was Dr. W. F. Evans, a patient under Quimby a few months after Mrs. Eddy. Like Mr. Dresser, Dr. Evans was a man of rare character and considerable ability. Quimby won his confidence by curing him of a serious disease and he won Quimby's by his native worth. If Quimby had been looking in Mrs. Eddy's direction, and if he was her pupil rather than she his, as she professes, Dr. Evans, keen as he was, would have had some reason to suspect it. 
This is his description of Quimby as a healer :

There is profound philosophy underlying the cures effected by Christ, and a distinct school of medicine may be erected upon it. One of the marked characteristics of the system is the discarding of all drugs and chemical agencies, and the placing sole reliance on psychical forces and remedies. It recognises the supreme controlling influence of the mind over the body, the inner over the outward man, both in health and disease. The body seems to have been viewed by him not as the real selfhood, but as only the shadow of the soul, the inner life of man. It corresponds to or echoes the states and movements of the interior nature. Disease is not so much a mere physical derangement, in its primary principle, as it is an abnormal mental condition, an inharmony of the psychical element and force-a wrong belief, a falsity. This fixed belief, that was viewed as the root of the morbid outward condition, is not a mere intellectual act, and has no reference to a creed, but represents an inward condition, the state of the inner man, what the German writers on the philosophy of mind denominate the interior consciousness. This is the governing element, the controlling principle. The bodily state is the index to it. "As a man thinketh in his heart, so is he." Disease being in its root a wrong belief, in the sense explained above, change that belief and we cure the disease. By faith we are thus made whole. There is a law here the world will sometime understand and use in the cure of the diseases that aftlict man- 
kind. The late Dr. Quimby of Portland, Maine, one of the most successful healers of this or any age, embraced this view of the nature of disease, and by a long succession of most remarkable cures, effected by psychopathic remedies, at the same time proved the truth of the theory and the efficiency of that mode of treatment. Had he lived in a remote age or country, the wonderful facts which occurred in his practice would have now been deemed either mythical or miraculous. He seemed to reproduce the wonders of the Gospel history. But all this was only an exhibition of the force of suggestion, or the action of the law of faith, over a patient in the impressible condition. ${ }^{24}$

Into the vexed question of the Quimby manuscripts, which through the courtesy of Mr. George A. Quimby I have read, there is no need to enter. The evidence already presented is sufficient to acquaint the reader with the general principle that underlay Quimby's views. 'The manuscript which Mrs. Eddy used in the late sixties and the early seventies and regularly said was Quimby's is in complete agreement with the Quimby theory. An unbroken line of witnesses from 1862 to $\mathbf{1 8 7 5}$ all testify that Mrs. Eddy was in those years continuously making generous acknowledgment that she got her central principle from Quimby and that the Mrs. Eddy of 1862 rather than the Mrs. Eddy of 1888 is to be believed. 
Even if George A. Quimby had in $\mathbf{1 8 8 7}$ accepted Mrs. Eddy's proposition to publish at her expense the Quimby manuscripts on condition that she be allowed to determine whether they were Quimby's thoughts or hers, the situation would not have been changed. Even if the United States Court, in 1883, did decide that Arens's book was an infringement on the copyright of Science and Health, the deeper question of whether Quimby or Mrs. Eddy was the author of what were plainly Quimby's views when Mrs. Eddy knew him was in no way touched..$^{25}$ It could not be.

Mrs. Eddy stands or falls by her own words. The contradiction between 1862 and 1888 can only be explained away when witnesses are found covering the years from $\mathbf{1 8 5 6}$ to 1875 , to offset the testimony of the Quimby scrap-book, Mr. and Mrs. Dresser, Mrs. Crosby, Mr. George A. Quimby, Mrs. Walcott, the Wentworths, Mr. Kennedy, Dr. Evans, and Mr. Spofford. The contradiction in itself disqualifies Mrs. Eddy to testify at all in the unusual circumstances. Who then will come to the support of Mrs. Eddy of 1888 and 1907 against Mrs. Eddy of 1862?

The Committee on Publication manifestly can not. Christian Science, though Quimby 


\section{The Source of its Ideas}

had already used the name, had not been born. The committee, therefore, was not in existence. In a communication addressed to me May 3, 1907, the committee claims that Quimby " never knew or practised a method of giving a mental treatment. He was a magnetic practitioner and a mesmerist and never was anything else. . . . His practice did not differ from that of many other magnetic practitioners of his time. All this I can prove by conclusive, indisputable, documentary evidence." 26 But when, May 5, I went by appointment to Boston to make a careful study of the evidence, I was sadly disappointed. If the committee has such evidence, the public, which is passing on the Quimby issue in these days, has a right to see it and to weigh it carefully. Every day's delay is hurting the Mrs. Eddy of 1888 and 1907, and confirming the Mrs. Eddy of 1862.

Still insistent in my search for witnesses who can speak for Mrs. Eddy of 1888 and 1907 against Mrs. Eddy of 1862, whom all the witnesses now known support, the Committee on Publication earnestly advised an interview with the author of the Human Life series. But when, on June 13th, I went to Boston by appointment for this interview I once more 
suffered disappointment. 'The author, like the Committee on Publication, has apparently found no witnesses; and since, as she had already written me, her " information is exhaustive," it begins to look as though the only witnesses who can be found to refute Mrs. Eddy of 1862 are those who never even knew her then. ${ }^{27}$

While we await the witnesses we need, a brief comparison of what we know was Quimby's with Mrs. Eddy's masterpiece may be worth the while. The deadly parallel does not always prove its case. There may be similarity of view without plagiarism. But when similarity shades off into practical identity in thought and word alike there is but one conclusion to be reached. The passages in parallel speak for themselves and from them there is no appeal conceivable.

DR. QUIMBY.28

MRS. EDDY.

1. "Christian Science." 1. "Christian Science."

2. "Science of Health." 2. "Sci e n ce a n d Health."

3. "Matter has no in- 3. "Matter cannot protelligence. duce mind."

4. "Matter is an error." 4. "Matter is a mortal error." 
5. "Understanding is 5. "Understanding is a God."

6. "Truth is God." quality of God."

7. "God is Principle."

6. "Truth is God."

8. "Wisdom, Love, and Truth are the Principle."

7. "God is Principle."

8. "Adhere to ... Principle, and follow its behests, abiding steadily in Wisdom, Love, and Truth."

9. "All sciences are 9. "All science is of part of God." God."

10. "The idea, man is the highest-hence the image of God."

11. "Error is sickness. Truth is health."

12. "The patient's disease is in his disbelief. . . If you are not afraid to face the error and argue it down, then you can heal the sick."

11. "Sickness is part of the error which Truth casts out."

12. "Science not only reveals the origin of all disease as wholly mental, but it also declares that all disease is cured by mind." 


\section{CHAPTER IV}

\section{THE FOUNDER OF THE FAITH}

The World when she was Born-Childhood-Environment and Education-First Marriage in 1843-Widowhood and Invalidism-Second Marriage in 1853-Visit in 1862 to Quimby-His Healing System-Mrs. Eddy's Great Mistake-The "Final Revelation" in 1866Separation from her Second Husband and Divorce -Professional Visiting-Partnership in Lynn with Richard Kennedy in 1870-Established as a LeaderRelationship with D. H. Spofford-The docile Mr. Eddy-Third Marriage-Christian Science organised in 1875-Removal in 1881 to Boston-Court and Cabinet-College and Church-To Concord in 1889Christian Science To-day-An Astonishing Autocracy-The Manual-The Modern Mona Lisa-Her Virtues and her Faults.

\section{MRS. EDDY is no longer young. She was born the summer of Napoleon's death, in 1821. She was closer that year to the American Revolution and the War of 1812 than babies born this year are to the Civil War and our recent war with Spain.}


Always a New Englander in point of view, Mrs. Eddy grew up with New England. The prestige of Virginia was waning. New York's was yet to be. New England was generating for the entire land ideas in politics and in religion, and was indulging to the full her native penchant for the mystical.

Clairvoyance, spiritualism, mesmerism, and other psychical phenomena were in the air. There was discussion of them on the lecture platform and at every cross-road. Mesmer was dead but mesmerists were everywhere in evidence. ${ }^{1}$ Charles Poyen was talking in many places where Mrs. Eddy later lived, about the "Power of Mind over Matter," and was making ready for the publication in $\mathbf{1 8 3 7}$ of his book on Animal Magnetism in Nero England. What Braid had done in England to make mesmerism popular, Grimes was doing in New England, and Dods and Stone were proving his apt pupils. Andrew Jackson Davis, also, was astonishing audiences by his mesmeric performances.

At Canterbury, five miles from the place where Mrs. Eddy lived from her fifteenth to her twenty-second year, the Shakers, whom Mrs. Eddy's brother's preceptor-at-law, Franklin Pierce, later President of the United 
States, defended in the courts, were ever thinking of their extraordinary leader. She had died long years before, but they were still speaking of her as the "Mother," "the female principle of God," " the female Christ "; using such terms as "Father-Mother God," "the Church of Christ," the "Mother Church"; and refusing to pray audibly and setting celibacy high above the marriage state.

Mrs. Eddy comes of good New England stock. On both sides she has a pedigree of thrift, honesty, and intelligence above the average. Her father, Mark Baker, was able, upright, conscientious, and fearless, though dogmatic, high-tempered, and hard-fisted. Accounts agree in making her mother, neé Abigail Bernard Ambrose, capable, gentle, and unselfish. ${ }^{2}$

Born at Bow, New Hampshire, July 16, 1821, the youngest in a family of six, Mary A. Morse Baker proved to be the only member of her family who achieved national distinction. Her brother Albert, nominated for Congress in 1841, might have proved a worthy second had he not died at the age of thirty-one before he was elected. The loneliness of a childhood spent on the ancestral farm was accentuated by delicacy of health which saved her from the 
drudgery that usually falls to the New England girl brought up in the country, gave her time to read such books as were at hand, and brought out both the defects and the virtues of her character.

In 1836 Mark Baker sold his farm and moved to town, Sanbornton Bridge,-now Tilton. Life was larger and more interesting at "The Bridge." Mary Baker, then fifteen, blossomed out at once into the village belle. Of medium height, slim and graceful, exquisitely moulded even to her hands and feet, features regular and refined, big blue eyes which could flash black on occasion, the fresh bloom of a pure complexion, an abundance of bright brown hair, escaping in ringlets from beneath her bonnet, always gowned in good taste and yet mindful of observers, Mary Baker was the cynosure of every eye as she came tripping every Sunday into church.

Already conscious of the power which has given her a distinctive place among women, she invariably took the centre of the stage. She expected and accepted the peculiar consideration given to her instinctively by everybody in the family and friendly circle. When her sweetness and her charm, however, were not adequate to win the influence desired, she 
knew how to challenge and command. Highstrung and hysterical, she knew when to employ the arts of the neurotic. Imperious and masterful in girlhood as in womanhood, she always played the game of life to win. Independent in her judgments even then, she won exemption from belief in predestination, when at the age of seventeen she joined the Tilton Congregational Church.

Schools are for the average and Mary Baker was no average girl. The stories of her school-days are the stories many people tell about the school-days of extraordinary people. Her schoolmates found her indolent and indifferent to the routine to which they yielded without murmuring. Ill-health and daydreaming are not conducive to the plodding of the school room. Her father, therefore, wisely kept her "much out of school" she says, and without hurt to her. ${ }^{3}$

One may be permitted, however, not to accept too literally her statement that she was studying those years, under her brother Albert, Natural Philosophy, Logic, Moral Science, Hebrew, Greek, and Latin. There is nowhere in her writings substantial evidence that she was well grounded in these subjects. Real learning does not vanish like a dream as 
Mrs. Eddy says hers did when she discovered Christian Science. If one is obliged to draw any inference as to her schooling from the facts in evidence it will, perhaps, be not unlike that which her schoolmates stated in the homely words: "Mary Baker completed her education when she had finished Smith's grammar and had reached long division in arithmetic." 4

Marriage was inevitable. The craving for the new experience is insatiate in a personality as highly sensitised as Mary Baker's was. And so when George Washington Glover, big, kind-hearted, and industrious, came a-courting she did not say him nay. They were married in December, 1843 , and went to South Carolina to live, where he died six months later of yellow fever. Helped north by the Free Masons because her husband was a Mason, Mrs. Glover gave birth the next September in her father's house in Tilton to a son whom she named for his father.

The years that followed are too sad and bleak for full description. The widowed mother, just past twenty-three, was lapsing from frailness into an invalidism which was not to lift till she was almost fifty. Her baby fell into the hands of kind but ignorant care-takers, grew up without education, and 
has seldom seen his mother since his babyhood. Her mother was old, her father past his prime. There was no place for her at home, and her brothers and sisters, with homes of their own, were not inclined to make one for a sister who in spite of many native gifts lacked the grace of adaptation. Mrs. Glover was discouraged. She made one short-lived effort to support herself by teaching. Then after her father's second marriage she entered on a sad and sordid life of drifting which continued till Richard Kennedy came to her relief in $\mathbf{1 8 7 0}$ and by his industry and generosity made her for the first time in her life economically independent.

She lived with one relative for a time, and then passed on to the next who would receive her. Poor relation as she was in every home, she acted steadily as though her presence was a privilege to be impressed on those with whom she lived. She took the best they had to give as though it were her right. She had the family life adjusted to her nerves. She made herself the centre of each situation. She gave the servants extra trouble if there were servants in the house. If there were not, she let it sometimes fall upon a hostess old enough to be her mother.

If the thought of helping on, as others do 
who fall into her plight, ever crossed her mind, she carefully safeguarded it from practical expression. To spend your time writing books and entertaining callers while your hostess plays the drudge, to queen it at the sewing circle and the "lodge" when there are duties to be done in the home where you are staying, does not tend to the perpetuation of the welcome, however gladly it may at first have been given. And so in all those bitter years, which ran on from 1843 to 1870 , Mrs. Eddy was engaged almost continuously in wearing out her welcome and in saying good-bye to the past.

She sometimes received attention from the other sex. She had to have it. Admiration was the breath of life to her. She touched at last the heart of an itinerant dentist, Dr. Daniel Patterson, who was rough but genial, and when he gave her sympathy in her forlornness and her invalidism, she married him in 1853.

But her second marriage did not end her troubles. It prolonged them. One who knew her husband tells me, "Dr. Patterson was too slow for her." He was not a good provider. He could not always earn a living as a dentist and so he sometimes practised homøeopathy and even turned his hand to running a saw-mill. They lived for years a pre- 
carious existence, moving from place to place, - Tilton, Franklin, North Groton, Rumney. Incompatibility of disposition and irreconcilable standards led in 1862 to a separation, when Dr. Patterson went off to the Civil War as a spectator, only to be captured by the Confederates and to fall into Libby prison. After his return some two years later, there was another unsuccessful effort made in Lynn to live together, followed by final separation in $\mathbf{1 8 6 6}$ and by divorce in $\mathbf{1 8 7 3 .}$

After the last separation her plight was worse than ever. She was now estranged from practically all of her own flesh and blood. She had lost one husband too soon after marriage for assurance that the marriage would have proved a happy and successful one. She had lost another husband through the utter failure of the marriage. She was the mother of a son now grown to man's estate but whom she had not seen for years and in whom she seemed to have so little interest as to perplex her good friend Mrs. Crosby, busy and contented with her babies. She had few friends. They invariably have few who count friendship a field for exploitation. She had no plan in life except apparently to eat bread that she had not earned and would not help to bake. 


\section{The Founder of the Faith}

She had no point of view to insure straight looking out on life and no philosophy to lift her out of self. That she was to find in her search for health.

All the years of her domestic infelicity and chronic invalidism Mrs. Eddy was thinking, she now says, of the possibilities of spiritual release from pain. After Dr. Patterson went south in the summer of 1862 , she made a visit to Portland, Maine, a nerrous wreck, attracted by the stories of the "wonderful cures" a certain Dr. Quimby had been making without drugs. ${ }^{5}$

Phineas Parkhurst Quimby was then a man of sixty. Son of a blacksmith of scanty means, he received but little schooling. Apprenticed as a boy to a clock-maker, he early showed those keen powers of observation, inventiveness, and originality of thought which made him a marked man his whole life through. A truth-lover and truth-seeker by instinct, he never took opinions ready-made. He read much. The Bible was erer in his hand, and sometimes Berkeley. He was well informed on current topics, thought clearly, and was apt to put his thoughts on paper.

Such a man was certain to be interested in the occultism which in his young manhood 
swept through New England. He followed Charles Poyen about from place to place and learned how to do his mesmeric tricks. In the forties, "Park Quimby" and his subject Lucius Burkmar, became household words in many a New England and Canadian village. ${ }^{6}$

Quimby, with his love for man, soon graduated out of the spectacular into the beneficent and turned his mesmerism to the good account of healing. But, like Bernheim of Nancy and Dubois of Berne in more modern times, Quimby by and by discovered that in suggestion lies the secret of all mental healing, and that its exaggerated forms, as seen in mesmerism and hypnotism, are seldom needed to effect a cure. Long before Mrs. Eddy came his way, he was leaving mesmerism behind and, as one of his old friends wrote to me, June 16, 1907, when Mrs. Eddy knew Quimby " nothing was more apt to excite him than the suggestion that there was mystery in his theory or practice."

At least three years before Mrs. Eddy sought his help, he was beginning to reduce his theory of healing to writing. With his own hand he put his thoughts on paper. $\mathrm{He}$ had the clerical assistance of the Misses Ware, daughters of a judge of the United States 
Admiralty Court, and of his son, George A. Quimby. Mr. Horatio W. Dresser, son of Mr. J. A. Dresser, who was not only one of Quimby's patients before Mrs. Eddy came to him in 1862 but also often explained Quimby's theory to Mrs. Eddy, several years ago talked out the matter with all those who gave Quimby clerical assistance in his writing and himself later copied several hundred pages, which on his father's and his mother's word, as well as on that of George A. Quimby and of the Misses Ware, he was assured was Quimby's intellectual production.

Mr. George A. Quimby thus describes his father's way of working: "From that time (1859) he began to write out his ideas, which practice he continued until his death, the articles now being in the possession of the writer of this sketch. The original copy he would give to the Misses Ware; and it would be read to him by them; and, if he suggested any alteration, it would be made, after which it would be copied either by the Misses Ware or the writer of this, and then reread to him, that he might see that all was just as he intended it. Not even the most trival word or the construction of a sentence would be changed without consulting him. He was given to repetition, 
and it was with difficulty that he could be induced to have a repeated sentence or phrase stricken out, as he would say, 'If that idea is a good one, and true, it will do no harm to have it in two or three times.' He believed in the hammering process, and in throwing an idea or truth at the reader till it would be firmly fixed in his mind."

Between 1859 and 1866, when Dr. Quimby died, he produced in this way-so characteristic of literary workers in these typewriter days-ten volumes of manuscript. Much of this-" over eight hundred closely written pages covering one hundred and twenty subjects" 7 -was written before Mrs. Eddy paid him her first visit in the autumn of 1862 . She probably never saw a page of the original manuscript. The copy which she made in 1862 of the first volume was a copy of a copy made by Julius A. Dresser and loaned by him to Mrs. Eddy. Her claim in later years that the Quimby manuscripts were her own manuscripts which she had left with Quimby years before ${ }^{8}$ can be established only by discrediting all the other witnesses and by denying facts themselves. Her unexpected assertion that certain quotations from Quimby's manuscripts "were my own words, as near as I can 
recollect them," is offset by the statement of Horatio W. Dresser, who like the author is familiar, as Mrs. Eddy is not, with the Quimby manuscripts in general, that the words in question "were from an article written by Dr. Quimby in 1863, copied by myself into a book, which Mrs. Eddy never saw, from the manuscript of Dr. Quimby's writings, copies from the original not a page of which Mrs. Eddy ever saw."

To doubt in the light of Quimby's history, in the well-known circumstances that surrounded the production of his manuscripts, in the face of all the witnesses who have testified to the development of his healing system, in spite of the words of Horatio W. Dresser, who found, as has the author of this book, hundreds of pages of manuscript written before Mrs. Eddy ever went to Dr. Quimby containing "a very original and complete statement of the data and theory of mental healing," that Quimby had a healing system of his own for which he owed no debt to Mrs. Eddy, is to prove oneself unappreciative of the psychology of intellectual production and literary expression.

To dispel the morbid fancies of the moody Cowper, Lady Austen once told him the old story of the London citizen riding to Edmon- 
ton, and ever since that day John Gilpin, started by the word of Cowper, has been galloping through the thoroughfare of AngloSaxon verse, and Lady Austen never once claimed any credit in the matter.

Dr. Quimby had started on his mental healing course years before his most distinguished patient ever heard of him. The most she ever did for him who did so much for her, was to give to him while he was alive the appreciation precious beyond words to every doctor, and after he was dead fulsome verse in which she made "sackcloth clothe the sun and day grow night." And then, as years went by and ambition grew with what it fed on, she began to claim first that she had started Quimby on his course, then that she, not he, had planned the course, and last, that he had not taken any course at all of mental healing, but was a mere mesmerist. And only in the high noon of this year's publicity has truth crushed to earth risen once again to the defence of Quimby and the depreciation of his one-time friend and pupil-patient.

When Mrs. Eddy, then Mrs. Patterson, was helped up the stairs in October, 1862, to Dr. Quimby's office, she was " a frail shadow of a woman." The beauty of her early womanhood was gone. ${ }^{9}$ Pale, emaciated, shabby, 
the stamp of poverty as well as illness on her face and form, her first request of Quimby was to assist her to secure an inexpensive boarding-place. Three weeks later she left him, a well woman,--well in body and in mind. Quimby had cured her of her nervous trouble, but that was the least that he had done for her. He had given her the idea which was to dominate her whole life, the rock on which she was by and by to build her church, against which she has been wont ever since stoutly to assert "the gates of hell shall not prevail."

What she had ever heard before of the idea we may not know. Mrs. Eddy is the only witness who can testify and she contradicts herself. She told the "Masters," August 14th, in the recent lawsuit, that the idea came to her before her eighteenth year. But she has in other instances borne different testimony. The one thing we surely know is this: She had at last a great idea. It came to her in all its force and fulness with Quimby's stamp on it. But it was hers; hers even to the repudiation-if she pleased-of the Quimby stamp. Generous to carelessness, scientific in the true sense of claiming no proprietary right in any truth he found, Quimby went on his way in cheerful godliness.

For many a year Mrs. Eddy seemed to be 
the winner in the so-called Quimby controversy. But this year she is losing, and at the age of eighty-six, when "visions that charm and bless" alone should visit her, Mrs. Eddy has to face the ghost of her ungenerosity which has enlarged her fame as founder of the Christian Science Church at the expense of her reputation as a woman. Even from the standpoint of mere policy, it has been a mistake not to acknowledge in these later years, as she did in the earlier ones, the efficient source of the idea on which she has erected a structure Quimby would never claim as his, but which could not have been built at all except on the foundation laid by Quimby in the receptive mind of Mrs. Eddy.

It was in Lynn, where she and her husband lived a while before their final separation, that she had the great experience from which in later years she dated her discovery of Christian Science. Returning February 1, 1866, from the "lodge," she slipped and fell on the icy sidewalk, sustaining a nervous shock which the physician, Dr. A. M. Cushing, at once ameliorated and in a fortnight cured.

Mrs. Eddy's recollection materially differs from her doctor's. ${ }^{10}$ She thinks she was critically ill. The doctor tells me she was not 
and he never said she was. He says she had sustained a nervous shock, which every doctor understands. She says that after his first visit she ceased to take his medicines. $\mathrm{He}$ tells me that she told another story at the time and that he had satisfying proof that she did follow to the letter his directions. She describes in some detail how she depended solely upon God, read the story in the Bible of the healing of the palsied man by Jesus Christ, caught "the lost chord of Truth, healing, as of old, from the Divine Harmony," and the third day rose as one from the dead, appeared before the friends who had gathered in the adjoining room to say good-bye to her, and was at first believed to be an apparition. The doctor, understanding that hysteria is, as Charcot says, nothing but "a psychic disease," would not have been surprised had she appeared even earlier before her friends.

She had done, it seemed, forevermore with doctors and their drugs. And yet the August following she called on Dr. Cushing once again to treat her for a cough. Belonging to a class of persons described by Professor Münsterberg, who, through weakness of the powers of perception, through inattention due to introspection, through misdirected volition 
or deficient suggestibility, or through some psychical abnormality to which Mrs. Eddy in her neuropathic state must then have been liable, are unable, even with the best intentions, to recall details with precision, her word-any nervous patient's word-cannot count against the word of a trained diagnostician. Dr. Cushing's judgment will undoubtedly be taken by the medical fraternity. Mrs. Eddy's case is a familiar one; her symptoms are accurately symptomatic of the disease.

It was a wretched life she lived in Lynn after the final separation from her husband. ${ }^{11}$ She was physically and temperamentally unfit to earn her living. She did not play successfully the rôle of the professional visitor. She could not efface herself in any home. She neither helped along nor kept hands off the family affairs. She could not master the simple lesson, easily learned by normal people who visit much, of leaving the family, enlarged to take her in, more closely knit together because she had been in it. There are families which still feel the strain she put upon them years ago.

The Russells and the Newhalls of Lynn were quit of her as soon as possible. The Wheelers and the Ellises of Swampscott 
passed her on-no easy task. At the Crafts', in East Stoughton, she was made more welcome, but there too she brought discord, no matter whose the fault. At the Websters' in Amesbury, though not herself perhaps a spiritualist, she trained with spiritualists until they, too, grew weary of her presence and had resort almost to force to send her off. Miss Sarah Bagley was a little kinder to her. But by and by Mrs. Patterson, then calling herself Mrs. Glover, went to Stoughton and spent two years before 1870 in the home of Mrs. Sally Wentworth, who was more than kind to her.

Of Mrs. Eddy's life there we know more than of her life elsewhere in those years. ${ }^{12}$ Mr. and Mrs. Wentworth are not living. But the son, Horace T. Wentworth, the wife whom he brought home as a young bride, Mrs. Arthur L. Holmes (then Lucy Wentworth), and a niece, now Mrs. Catherine Isabel Clapp, are alive and retain vivid memories of that visit. They tell me the same story of a favourable first impression passing into the usual strained relationship as the daily contact unveiled a nature self-centred, at the cost of family peace and happiness. She had made trouble a while before between Mr. and Mrs. 
Crafts, and now she was sowing the seed of the same possibility in the Wentworth home by trying to persuade the wife to go off with her and practise the Quimby healing.

Here as elsewhere there was an aloofness from real life that made more work for the housewife and that once found expression, to the disgust of a young mother (Mrs. Horace T. Wentworth), in the characterisation of her new-born babe as an "embryo of human mentality." Mrs. Holmes, then Lucy Wentworth, in her teens and devoted to Mrs. Eddy, tells how Mrs. Eddy put into her head the nonsense that she was made of finer clay than other members of her family. She also recalls that when Mrs. Eddy was not writing in her room or talking with the family or strolling along country roads, she was likely to be found, Lucy Wentworth with her, reading the spiritualistic journal, The Banner of Light, or the back numbers of the New York Ledger, with their stories of cloying sweetness and their highpitched sentimentalism. Mrs. Southworth's stories seemed to have a special charm for Mrs. Eddy, and if her reference in a personal letter to "Irving's Pickwick Papers" 13 be in evidence, she could not in those days have had much interest in Dickens. 


\section{The Founder of the Faith}

Here, as elsewhere, her supreme interest was Quimby. For the consideration of three hundred dollars, to be "boarded out," she taught all she knew of Quimby to Mrrs. Wentworth, who had a native talent for healing without medicine. In teaching Mrs. Wentworth she used a manuscript, which she allowed her pupil to copy, and which we know was Quimby's not only because Mrs. Eddy said so but also because it is, as I have found, almost word for word identical with a Quimby manuscript owned by George A. Quimby, and in his mother's handwriting, bearing the date February, 1862, eight months before lirs. Eddy first met Quimby.

All those months, Mrs. Eddy was consumed with a desire to put the Quimby theory into a book. She was ever writing at it, ever trying to find funds for its publication. She was even willing that Mrs. Wentworth, without her husband's knowledge, should put a mortgage on the place to secure the money needed. She talked Quimby until every one grew "dead tired of hearing" of him, and Mrs. Clapp, in imitation of the Quimby propagandist, would fold her hands softly in her lap, smile gently, nod her head slowly and remark: "I learned this from Dr. Quimby, and he made 
me promise to teach it to at least two persons before I dic."

There, too, in Stoughton, the inevitable hour struck when how to say good-bye to Mrs. Eddy without a scene, became the burning issue. There too, as elsewhere, it was not managed with complete success; for Mrs. Eddy left behind when she at last departed evidences of her frame of mind not to be mistaken or forgotten.

The summer of 1870 found Mrs. Eddy once again in Lynn. She was now entering her fiftieth year. Her great contemporaries Lincoln, Stanton, Seward, Chase, had finished their life work, and two of them were dead. Mrs. Eddy was still making ready for a career as remarkable in many ways as theirs. She was now about to taste some of the sweets of the success hitherto denied her.

No evidence has yet appeared that, in the years that lay immediately behind, she had shown much interest in healing, or that she had much power to heal. In the Wentworth home, she had shrunk instinctively, like any other nervous woman, from the sick-bed of others, and had shown such a morbid fear of death that Mrs. Wentworth often wondered what there could be in her past to make death 


\section{The Founder of the Faith}

seem so dreadful. Mrs. Eddy's one interest was to teach Quimbyism, to "carpenter" it out into a book, and find the means to publish it. What she needed most was some one who could illustrate her theory by effective healing.

Him she found in Richard Kennedy, ${ }^{14}$ a brown-haired, ruddy-faced, enthusiastic, goodnatured, industrious, studious, clear-headed, and clean-minded youth just coming into manhood. The two opened offices together. $\mathrm{He}$ healed with much success. His offices were crowded. Money poured into the treasury. At the end of eighteen months she who had been a poor relation and a professional visitor practically all her adult life found to her credit in the bank the neat sum of $\$ 6000$.

While her partner healed, and paid all bills for both, Mrs. Eddy taught, and though the major portion of her profits came from Richard Kennedy's generosity she also contributed to the adequate bank account she now had for the first time. In the new atmosphere of financial independence, some of the small conceits and the ingratiating mannerisms began to disappear. She did not try so hard to please the uncongenial. There was no pressing need. Though by no means a recluse, she 
wanted social contact only on terms of her own choosing. They who would have her good-will had to pay the price, as Mr. Kennedy informs me, of " dancing round her like a Maypole."

As months slipped by, she grew more assertive and ambitious. Once in a burst of confidence she said to her young partner, in whom people to this day instinctively confide, "Richard, I was born an unwelcome child, and I mean to have the whole world at my feet before I die." As Quimbyism in her thought began to grow by accretions which Quimby would not always have approved, she looked far into the future, saw a popular religion upbuilding on the book she was one day to publish, and with eyes lighted by the supreme faith she had even then in her own powers she said more than once to Richard Kennedy, "You will live to hear the church bells ring out my birthday." And the prediction has already been fulfilled. The bells of her own church at Concord rang out her birthday, July 16, 1904.

As students multiplied, she grew more certain of herself. For twelve lessons, her first students paid her $\$ 100$ each, promised her a life annuity of ten per cent. of all 
their future earnings, and gave a $\$ 3000$ bond not to show to any one the copy she allowed them to make of the manuscripts now grown from Quimby's one to three. At the end of three weeks she saluted them as "Doctor," and sent them out into the world to practise Quimbyism without the name of Quimby. Moved, she says, " by a strange providence," 15 she raised her charges in a little while to $\$ 300$ for twelve lessons, reduced in later years in Boston to the number seven.

Never able permanently to retain those who would not give their heart and mind completely to her keeping, she soon began to lose some of her more thoughtful students. Writes one of them to me: "As a teacher she considered herself the wisdom and in all things was to be cbeyed; any one going contrary was in rebellion and must be put down. In the class she strove to prejudice her students against any rebellious ones through awakening as much sympathy as possible among the loyal by informing them that she was caused both mental and physical suffering by their misconduct."

One woman left her class because she thought Mrs. Eddy " was taking Christ away from her." Another through the court recovered her tuition fee on the ground that she 
had not received her money's worth. Some sued her'; others she sued. 'The air was thick with litigation. With some of the choicest spirits her system broke down of sheer absurdity as she began to put it to unnecessary strain. One student was so disgusted by her claims that she could raise the dead-to which claims more than one have testified-that he challenged her to give a public exhibition. ${ }^{16}$

She had her stormy differences even with her youthful partner, whom it would be difficult to-day for any one to differ with in anger, and after he performed the thitherto impossible feat in $\mathbf{1 8 7 2}$ of breaking with her without any public scene, and went off to complete alone the establishment of the reputation which he now enjoys for courtesy and integrity, she followed him like any mediæval pope with her anathemas, made him the occasion of the development of her strange obsession of Malicious Animal Magnetism, singled him out nine years later for furious denunciation in the third edition of her book, and at last dismissed him with the inappropriate characterisation, "the Nero of to-day." 17

But every time she lost a follower another came to take his place. Disciples increased alike in zeal and numbers. Those who came 


\section{The Founder of the Faith}

to stay passed under the spell she put upon them. Her influence had no necessary relationship to the system she was teaching. It would have been as dominating had she been preaching Comtism or Mormonism. It was not, as some have thought, humbuggery that attracted many, but a hypnotic influence-the power Mrs. Eddy has of profound and, to some, irresistible suggestion, which none of her conspicuous contemporaries, except perhaps Gladstone, had in such large measure.

Of Mrs. Eddy and her students in those early days Georgine Milmine draws this vivid and veracious picture:

The closer students, who constituted Mrs. Glover's cabinet and body-guard, executed her commissions, transacted her business, and were always at her call. To-day some of these who have long been accounted as enemies by Mrs. Eddy, and whom she has anathematised in print and discredited on the witness-stand, still declare that what they got from her was beyond equivalent in gold or silver. They speak of a certain emotional exaltation which she was able to impart in her class-room; a feeling so strong that it was like the birth of a new understanding and seemed to open to them a new heaven and a new earth. Some of MIrs. Glover's students experienced this in a very slight degree, but such as were imaginative and emotional, and especially those who had something of the mystic in their na- 
ture, came out of her class-room to find that for them the world had changed. They lived by a new set of values; the colour seemed to fade out of the physical world about them; men and women became shadow-like, and their own humanity grew pale. The reality of pain and pleasure, sin and grief, love and death, once denied, the only positive thing in their lives was their belief-and that was almost wholly negation. One of the students who was closest to Mrs. Glover at that time says that to him the world outside her little circle seemed like a madhouse, where each inmate was given over to his delusion of love or gain or ambition, and the problem which confronted him was how to awaken them from the absurdity of their pursuit. It is but fair to say that occasionally a student was more of a royalist than the king, and that Mrs. Glover herself had a very sound sense of material values and often reminded an extravagant follower to render unto Caesar what was his due. ${ }^{18}$

By 1875, Mrs. Eddy's following was large enough to warrant the establishment of permanent headquarters. A house, still standing, was therefore bought in Lynn, and in a lowceiled room on the third floor Mrs. Eddy completed, with money furnished her by her students, the manuscript of Science and Health, gave it to the world, and prepared the second and third editions for her publishers.

It was this year that Daniel $\mathbb{H}$. Spofford 
cast in his fortunes with her. They had met four years before. He had since become interested in her work, made a careful study of her manuscripts, and won some reputation as a healer. In April, 1875, she induced him to join her class, treated him with marked distinction, gave him the pen with which she wrote Science and Health, made him treasurer of the Christian Science Association formed next month for the conduct of Sunday services in a public hall, and when the following autumn her book fell still-born from the press, it was to Mr. Spofford that she turned to advertise and push its sale. A gentle dreamer, ever on spiritual business bound, Daniel H. Spofford had none of Richard Kennedy's impulsiveness and easy savoir faire. But he had the same sense of devotion to his duty as he saw it.

Like Mr. Kennedy, effective as a healer, Mr. Spofford was successful also as a teacher. Complications, however, came as usual, and various explanations have been given of them. The next spring it was evident that Mrs. Eddy was cooling toward her favourite. ${ }^{19}$ The summer brought the open break, and in January, 1877, Mr. Spofford was expelled from the Christian Science Association on the 
serious charge of immorality, by which Mrs. Eddy simply meant disloyalty to her. ${ }^{20}$

As she had followed and was still following Richard Kennedy with her frenzied thought, charging him with mesmerism, developing in her heated mind the curious theory of malicious animal magnetism which was not found in Quimbyism, so now she followed Mr. Spofford, mild and serene as he was, to the ridiculous extremity of causing him to be haled into the Salem court in the spring of 1878 on the charge of witcheraft, which the judge dismissed with the smiling explanation that "it was not within the power of the court to control Mr. Spofford's mind." ${ }^{21}$ The last strange chapter in as strange a story as ever yet was told of Mrs. Eddy's strange career was the indictment the following December of Asa Gilbert Eddy, Mrs. Eddy's husband, and Edward J. Arens, one of her students, by the grand jury on the charge of conspiracy to murder Daniel H. Spofford. The evidence was dubious and inconsequential. No inference can to-day be drawn from it except that there was probably hysteria on one side and panic on the other. The case was nolle prossed, and never came to trial. ${ }^{22}$ Mr. Eddy paid the costs, and Mr. Spofford still lives and 
at the age of sixty-five enjoys the confidence of those who know him well.

It was through Mr. Spofford that Mrs. Eddy met Asa Gilbert Eddy. Her first husband had been dead thirty years and more. She had been divorced in 1873 from Dr. Patterson, and it was to Mrs. Glover, and not Mrs. Patterson, that Mr. Spofford presented one of his new patients, Asa Gilbert Eddy. To speak with gravity of this new friend, who, unlike many another, came into Mrs. Eddy's life to stay, is far from easy. When after five years of married bliss he passed from earth, Mrs. Eddy summed him up with the Psalmist's challenge, "Mark the perfect man." ${ }^{23}$ But Mrs. Eddy's standard of perfection was evidently not the Psalmist's. Unquestioning obedience to her has invariably sufficed to uptilt the horn of adulation even on the stupidest head.

From Mrs. Eddy's point of view Asa Gilbert Eddy was " a perfect man." Promoted from sewing-machine agent to successful pedler of Mrs. Eddy's precious book, from pedler elevated to the high dignity of husband to the author, Asa Gilbert Eddy yielded to his spouse the unquestioning obedience necessary to retain his place. He was a handy man for any wife to have about the house. He 
did what he was told to do. He would solicit students for his wife or take up the collection at the Sunday service when she preached the sermon. His sister-in-law remembers that "he could do up a shirt as well as any woman." Dull but thrifty, slow but steady, stolid but dutiful, superstitious but amiable, Mrs. Eddy's third husband furnished a better background for her erratic brilliancy than she had ever had before. Not even in her wildest dreams could Mrs. Eddy foresee in her docile helpmate, as in Mr. Spofford, a potential rival. No one would be likely, in all human probability, to rally to the rebel standard of a slow little man in a cinnamon-coloured overcoat and a fur cap, which he was known to wear, without sense of incongruity, even in the summer.

The marriage was a genuine surprise to all. T'o be sure the grand dame had allowed the little man to call her "Nary" in the classroom, but even then the announcement of the engagement was too sudden to be credible. When Mr. Spofford received from Eddy's hand the note that brought the news he remarked: "You've been very quiet about all this, Gilbert." “ Indeed, Dr. Spofford," the prospective groom replied, "I did n't know a thing about it myself until last night." ${ }_{24}$ 
On New Year's Day, 1877, Mr's. Glover, aged fifty-six, though the age appeared as forty in the marriage license, led to the altar the man of forty whom she took for her third trial marriage, and so well was she impressed with him that after three days, with that scant sense of the eternal fitness of things of which Mrs. Eddy has often given illustration in her life, she wrote one of her students: "I feel sure that I can teach my husband up to a higher usefulness, to purity, and the higher development of all his latent noble ${ }^{25}$ qualities of head and heart."

He was willing to be taught. He would even turn docility into self-effacement. There is no evidence that he objected to Mrs. Eddy's use of the editorial "we" in writing of herself or to her reference to him as "our husband." The marriage was, she says, a spiritual one. She had already made him "Doctor" after his twelve lessons with her in the art of healing. Now that he was completely hers, she made him " the first organiser of a Christian Science Sunday-school, which he superintended. He also," she says, "taught a special Bible-class; and he lectured so ably on scriptural topics, that clergymen of other denominations listened to him with deep interest. He was remarkably 
successful in mind-healing, and untiring in his chosen work. In 1882 he passed away, with a smile of peace and love resting on his serene countenance." And Mrs. Eddy spoke her "Well done, good and faithful servant" in these words: "Mark the perfect man, and behold the upright; for the end of that man is peace." ${ }^{26}$

A quarter of a century has gone since Mrs. Eddy was the last time widowed, and she has had no husband since to do her will. But in Calvin A. Frye, ${ }^{27}$ steward, bookkeeper, secretary, coachman, her "man of all work" as she herself has called him, she has had the while one singularly deroted to her and to her interests. To serve her he gave up all at the outset. Family ties were relinquished. Friendships were allowed to languish. It is said that never since the day he came, not knowing what her purpose was, in answer to her telegram, has he been beyond the reach of her voice for a whole day. Though from $\mathbf{1 8 8 2}$ to $\mathbf{1 9 0 0}$ he received only ten to twelve dollars a week and board, and for the last four years has been paid at most one hundred dollars a month and board, he has, according to his affidavit in the suit entitled $\boldsymbol{E} d d y$ rs. Frye et als., received in money and jewelry presents 
amounting in value to $\$ 7300$, and now has in bank $\$ 11,000$ to his credit. In addition, Mrs. Eddy, for reasons not divulged in his affidavit, at one time or another has assigned to him certain copyrights of her publications, deeds to her home, and to various other properties, and has had them at her will reassigned to her.

Stories have been so freely circulated by many-among them Dr. E. J. Foster, whom she adopted in 1882 but who according to his own report was driven out of Mrs. Eddy's heart and home by Frye's influence-of the unusual authority exercised by a coachmansecretary, that suit was, March 1st, instituted by her son and others to break this authority once for all. Frye's reply in his affidavit was that Mrs Eddy is sole manager of her affairs. Those nearest to her testified in the same terms. Mrs. Eddy stated clearly, June 15th, to a representative of the Boston Globe, "No living person abridges my rights in this house or governs my actions." Dr. Edward French, the expert alienist, July 10th, "was impressed with her intelligence and business ability" and pronounced her "competent to manage her own affairs." And no less an alienist than Dr. Allan McLane Hamilton found, August 12th, that "she is competent to take care of 
herself and manage her affairs and that she is not coerced in any way." It was therefore wise for the "next friends," whatever may have been their motive, to abandon their lawsuit on August 21st.

With a name, a book, a tentative organisation, and headquarters, Christian Science was fairly launched by 1875 . On the centennial of the nation's birthday in $\mathbf{1 8 7 6}$ the organisation was perfected and April 19, 1879, it was turned into a church. A charter was obtained in August, and Mrs. Eddy, called the same year by the little flock of twenty-six to be their pastor, was ordained in $1881 .^{28}$

The church was not, however, an immediate success. Lynn was already growing weary of the new faith and its founder. She was so often in the courts that the Boston papers were headlining her troubles with increasing facetiousness. Students one by one withdrew till once she had but two left. She was meanwhile, under the great strain, growing so difficult to satisfy that even her obedient husband once confided to a friend that he did " not believe God Almighty could please Mrs. Eddy." Realising that there was nothing more that she could do in Lynn she dissolved her: little church of less than fifty members, 
and early in the winter of 1882 beat a wise retreat to Boston.

She had for several years been reconnoitring there,--lecturing occasionally in 1878 in a Baptist church on Shawmut Avenue and in 1879 giving Sunday afternoon talks in the Parker Fraternity Building, on Appleton Street, to audiences ranging from twenty-five to fifty. By 1880 there were a few Christian Scientists meeting every week at the home of Mrs. Clara Choate. On Dec. 12, 1880, the services were transferred to the Hawthorne rooms on Park Street, and before Mrs. Eddy removed to Boston her habit was to come up every Sunday from Lynn, conduct the service, and preach the sermon.

In 1881 a charter was secured for the Massachusetts Metaphysical College. The college was at first designed to help her to rehabilitate herself in Lynn. It never had a building of its own. It met in MIrs. Eddy's parlour, and its faculty, consisting solely of Mrs. Eddy, was not as large as the faculty of that western college which Mr. Bryce once to his amusement found was made up of the president and his versatile wife. But the college grew in the face of all discouragements and out of it developed various organisations. At last in $\mathbf{1 8 8 6}$ 
the National Christian Science Association was formed, which met in general convention in New York City February 11, 1886. From S'cience and Health sprang new editions in bewildering frequency with passing years, various smaller books and brochures, The Christian Science Journal, published once a month and now in its twenty-fifth year, and at last The Christian Science Sentinel, this year in its ninth volume.

Mrs. Eddy was now coming to her own. Her organisations were developing. She too was growing steadily in the power to express herself with pen and tongue. There were still vagueness and verbosity in both her private correspondence and her published writings. But there was also a new ease evident. She was learning somewhat of the art of feathering the arrow of expression. More important still, she was beginning to submit her literary productions to others for censorship ere she gave them forth to that cold world which still is slow to take her at her own high valuation. Astute beyond description Mrs. Eddy had discovered that to make the most profound impression on an audience one must not speak too often and one must never speak except when in the speaking mood. She now began 
to limit the number of her public addresses and never hesitated to break her Sunday appointment if she were not " in the Spirit on the Lord's day." Her substitutes had to be ready at short notice to officiate and sometimes even then "after the audience at Hawthorne Hall had been waiting for perhaps half an hour, Mrs. Eddy's carriage would swing into Park Street, the horses on a trot, and she would alight amid a crowd of delighted students, sweep rapidly up the aisle, ascend the rostrum, and at once begin to deliver one of her most effective sermons."

A critic who heard her in the eighties in the pulpit and the class-room pays this tribute to her singular impressiveness:

"From hearing Mrs. Eddy preach, from reading her books, from talking to her, one does not get an adequate idea of her mental powers, unless one hears her also in her classes. Not only is she glowingly earnest in presenting her convictions, but her language and illustrations are remarkable. She is quick in repartee, and keenly turns a jest upon her questioner, but not offensively or unkindly. She reads faces rapidly. A brief exposition of the Book of Job, which one day entered incidentally into her statement of how God is found, would do honour to any ecclesiastic. Critical listeners are frequently astonished at the strength of her argu- 
ment and cogency of her reasoning, even when they cannot fully agree with her conclusions. While she is quick to detect variations from her own views, and to argue the point, she maintains the utmost repose in every debate. In fact, she is a natural class-leader, and three hours pass quickly away in her lessons." 29

At first she lived at 569, then at 571, Columbus Avenue, and in 1887 purchased a house in the Back Bay district, 385 Commonwealth Avenue, ${ }^{30}$ where the First Reader of the Mother Church is now directed by the Manual to reside. Her house was her strategic point for doing things and managing people. Classes were meeting all day long. There was little social intercourse and no idling. Butthere was much self-consciousness grown morbid through Mrs. Eddy's over-emphasis of malicious animal magnetism. She herself was troubled with nocturnal hysteria which she invariably ascribed to " M. A. M." as she familiarly designated it. It was not unusual for the whole family and even students living near to be called up at night to give her mental treatment. If the wash-boiler leaked or the waterpipes froze, "M. A. MI." was the malign agent to be withstood by the united effort of the little band of her retainers, whom at last she organised into the "P. M. Society," to 
present a solid front to the unseen and malignant foe. For years her house was the "House of Mesmer," and " resembled nothing so much as one of the small Italian courts of the fifteenth century; reputations were made or lost by an accident, and the favourite of to-day was the exile of to-morrow." " 31 It was in her home that she tested those who came her way. She drew them closer to her if she thought that she could use them; she sent them off if they would not do her will.

Sometimes her liking for new people was so quick and irresistible that she at once made them members of her household. One man, Dr. E. J. Foster, she legally adopted as her son, gave him the name of Foster-Eddy, had him live in her house, and serve her as accountant and publisher. His story of how his position was made impossible by another favourite of Mrs. Eddy's and how at last he fled in great alarm and still fears for his life, reads like a page from the Arabian Nights. Another, a woman, the cleverest perhaps that ever basked in Mrs. Eddy's sunshine for a season, became ambitious, claimed to have pushed Mrs. Eddy's views on the spiritual propagation of the species to their logical conclusion of "immaculate conception," and-to quote the title of 
the book she later wrote-in the War in Heaven which resulted, suffered the fate of Satan in Milton's poem.

Out of all the experiments of past years has been developed Mrs. Eddy's present cabinet, including Alfred Farlow, devoted to her now these twenty years and her official spokesman; Archibald McClellan, man of affairs and editor of the Christian Science periodicals, $\mathbf{H}$. S. Hering, First Reader in her church at Concord; Rev. Irving C. Tomlinson, a Congregational preacher turned Christian Scientist and now her loyal follower: Mrs. Laura E. Sargeant, her household companion and confidant for fifteen years; $H$. Cornell Wilson, her secretary; and Calvin A. Frye, who is, according to reports, nearer to Mrs. Eddy than any one else. ${ }^{32}$

The year 1889 is an epochal date in Mrs. Eddy's later history. It marks the closing of some of her efforts, the acceleration of others, and the initiation of new ones. She was now entering on the last and largest stage of her public life. Her college had, she says, succeeded beyond her fondest hopes. It was not merely filled, it was "flooded," with students paying their $\$ 300$ for a three weeks' course in mental healing. Students came not only from 
America but from Europe too,- - and in 1889 there were 300 on the waiting list. The unprecedented popularity of the institution gave Mrs. Eddy some concern. "Example has shown," she writes, "the danger arising from being placed on earthly pinnacles, and Christian Science shuns whatever involves material means for the promotion of spiritual ends." ${ }^{33}$

But there was another circumstance which possibly gave some concern, if one may read between the lines of her discussion of it. According to her words, the college charter she obtained in 1881 brought with it "the right to grant degrees." The act on which the grant was based, however, was repealed in 1882 . Next year the conferring of " any diploma or degree" by a "corporation" or "association," was made punishable by the courts. Mrs. Eddy claimed that her college did not fall under the heading of a "corporation" or "association" and was therefore in no wise affected by the law. But when there was some reason in 1889 to expect that her interpretation was not to be accepted without a test, she closed her college,-and the subject. ${ }^{34}$

Fertile as ever in resource, leaving nothing to chance, forestalling difficulties that might later prove embarrassing, she at once gave her 
students a new interest and by a bold stroke rallied all who might possibly have been discouraged by the closing of the college to the support of the church now, after some experimentation, to be developed to its utmost possibilities. The first proper step in the new policy was evidently to erect a building large enough to meet the growing needs of Christian Science and attractive enough to lure the casual. Before the year was at an end Mrs. Eddy gave as a site for the new church a lot worth, she says, "twenty thousand dollars," which had come to her for $\$ 5000$, "in a circuitous and novel way" 35 to quote her own words, " materially questionable," "the wisdom of which a few persons have since scrupled." It was on this lot that the granite building with a seating capacity of 1500 was erected in 1894 at a cost of $\$ 221,-$ 000, which now stands as a frontispiece to the colossal temple, seating 5000, completed in 1906 , at a cost of $\$ 2,000,000$.

It was a happy day for Mrs. Fddy when in 1889, actuated in part by patriotic sentiment, she removed to Concord, New Hampshire, a few miles from her birthplace. She was approaching the time limit which the psalmist sets for normal human life, but her 


\section{The Founder of the Faith}

natural force was far from spent. She was passing on toward old age with less infirmity than she had often felt in earlier years. And yet it was well for her that she then withdrew to Concord. The strife of tongues, the clashings of ambition, the inevitable frictions of a growing church, the " constant troubles in Boston" might possibly have qualified the unique prestige she enjoyed had she been near enough to be tempted to take a hand in all of them. ${ }^{36}$

It was Mahomet withdrawn to Medina who later dominated Mecea, and it was Mrs. Eddy removed to Concord who won prophetic eminence in Boston. ${ }^{37}$ If a new religion is to come to large proportions a cloud of mystery must some day gather round the head of the originator.

The founder of Christian Science has been fortunate to have her personality take on a little mystery before her death. At Concord she has been far enough away to arrange with dramatic detail the infrequent epiphany of pilgrims who have come from far and near to break their alabaster box upon her feet and to receive upon their reverent heads her blessing from the balcony of Pleasant View. At Concord she has not been so far away but that she could keep the reins of government well within 
her practised hands as those about her testify has been and is to-day her habit.

Christian Science is a movement of significance from the point of view of numbers. Mrs. Eddy claims more than a million followers. Certainly the whole world over there are those who call her blessed, and who prove their gratitude by building costly and commodious churches. The Christian Science congregations number now at least a thousand, of which perhaps three hundred are not regularly organised under state laws but are simply societies holding public services. The Mother Church in Boston reported June 11, 1907, a membership of 43,876 , and the total membership of the 645 branch churches which have reported, is now $42,846 .^{38}$

The aggregate membership, however, is not so large as might appear; for as the Publication Committee writes me, "All the members of the branch churches are eligible to membership in the Mother Church and I think it is safe to assume that a very large percentage of them belong to that society." To the enrolment, therefore, of 42,846 in the branch churches must be added not all the 43,876 in the Mother Church but only that relatively small percentage of them who are members of 
no church except the Mother Church. But on the other hand, the Committee on Publication bids us to remember, that there are many C'hristian Scientists at heart who are "situated as to their family relations and otherwise so that it does not seem advisable to sever their old connections at the present time and for that reason it is not easy to estimate the number of those who are actually interested." ${ }^{39}$

However numerous Christian Scientists may be, Mrs. Eddy is their ruler absolute. ${ }^{40}$ No earthly potentate has the authority which Mrs. Eddy now enjoys. If the whole world is not yet at her feet as she hopes it may be before she dies, she has worshippers enough to give some pertinence to proud ambition. Napoleon's one hope to perpetuate his throne was through a son. Mrs. Eddy is content to perpetuate her pulpit by a book. No one can succeed her in the Christian Science pulpit, which nowhere has a preacher, and in the place of a preacher, Science and Health, read by a reader chosen with her approval, is everywhere the Sunday sermon in connection with and in comment on the Bible.

Those who would know how absolute is Mrs. Eddy's will must read not Science and Health but the Manual of the Mother Church 
in Boston, of which it should always be remembered most Christian Scientists in the land are members. Mrs. Eddy claims for the Manual, prepared in 1892, as for Science and Health, that it was in its origin "impelled by a power not one's own." ${ }_{41}$ If Science and Health surprises one by its extraordinary theories, the Manual amazes us by the powers it entrusts to Mrs. Eddy.

Pastor Emeritus to Science and Health and not to any pastor in the flesh, Mrs. Eddy has all the authority she had when she was pastor without the wear and tear of pastoral relationship. The Church has its directors and trustees but they are responsible to Mrs. Eddy. The Church elects its readers but always from a list approved by Mrs. Eddy, and she can remove a reader without assigning any reason for her act.

Every application for membership must be passed upon by Mrs. Eddy. Every Christian Scientist is responsible to her for even some of the incidental interests of life. No Christian Scientist may read books on hypnotism or may patronise any publishers or booksellers who have books for sale that criticise the cause. No Christian Seientist may make bold to stroll by Pleasant View or to haunt Mrs. Eddy's drive 
or spend a while in Concord with the thought of seeing her. No Christian Scientist, either man or woman, may refuse at Mrs. Eddy's call to leave business, home, and kindred and go to live with her at Pleasant View for years if she so orders.

On each instance of infraction of these rules, Mrs. Eddy sits in judgment. She acts also as jury, and from her decision there is no appeal. She professes actual infallibility in dealing with those who practise hypnotism. "I possess," she says, " a spiritual sense of what the malicious mental practitioner is mentally arguing, which cannot be deceived; I can discern in the human mind thoughts, motives, and purposes; and neither mental arguments nor psychic power can affect this spiritual insight." +2

The directors of the Christian Science educational work are chosen subject to her approval, and she is president of the board besides. There are teachers, lecturers, missionaries-chosen ever with her consent-and even the minor employees of the Publishing Society are not selected save with her approval and are removable at her discretion.

Especially important is the Committee on Publication consisting of one member chosen with Mrs. Eddy's sanction, and receiving a 
salary of at least $\$ 4000$ a year. His business is to conduct the Christian Science propaganda through the press the whole world over, to correct misapprehensions in regard to Christian Science, to answer criticisms of Mrs. Eddy and the cause, and "to circulate in large quantities" his published answers. No explanation of the growth of Christian Science can be adequate that does not give full credit to the Committee on Publication. During Mr. Alfred Farlow's term of office, these eight years past, the Press Bureau has been brought to a high degree of efficiency.

Mrs. Eddy may be described as a Mona Lisa. If in the light of Mrs. Eddy's history, one may not say,

"She remains from perturbation free,

This woman that hath made all life her own," ${ }^{43}$ one may say that opinions of Mrs. Eddy differ as widely as those concerning the inscrutable woman who looks out from Leonardo's puzzling picture.

To some Mrs. Eddy has for many years seemed but the passive tool of designing men who play upon her vanity to put money in their purse. To others she is not merely, as one close to her has written me, the purest, wisest, most unselfish of women, ${ }^{44}$ but also as 
another devotee has said, "the transparency to this age, for the reflection of Grod to mankind." 45

Whatever secrets may lie hid behind her serene face, ${ }^{46} \mathrm{Mrs}$. Eddy is no ordinary woman. She is rich, famous, popular, and powerful. Author of a book which many thousands set above the Bible and study with devoutness every day, Mrs. Eddy has accumulated a great fortune out of its enormous sale. Head of a large and growing organisation of her own creation and as compact and obedient to her every wish as a modern army, Mrs. Fddy is beloved by all her subjects and by many of them practically deified.

Distinction either in authorship or organisation never comes by chance. With a great price it is purchased. To win world-wide fame, which thousands are profoundly sure will prove undying, both in authorship and organisation, is an achievement only those will underestimate who have not tried to purchase either.

And yet all the way along these forty years of such singleness of purpose as probably has never been surpassed by womankind, Mrs. Eddy has had heavy handicaps.

Always frail in health, she has not 
infrequently been positively ill. Untrained in early life to think, to write, to achieve, she was past fifty before she found herself. The impecunious sport of fortune, ill-fated in one marriage, unhappy in another, unaffected to any considerable extent by a third, thirty years out of her long life were filled with embarrassments, discouragements, mortifications, and temptations.

Interested more in her idea than in the people it drew to her she has suffered the forlornness which comes to those who sacrifice relationships to ideas. "I am alone in the world," she wrote to her son in 1898; "more alone than a solitary star. . . . My home is simply a house and a beautiful landscape. There is not one in it that I love, only as I love everybody." 46

Ambitious to have the whole world at her feet she has been teacher, leader, "Mother Mary," everything except the simple friend giving and receiving on those terms of entire equality which ensure the happiest as well as richest life. That was why a woman in whose home she took her meals in $\mathbf{1 8 7 2}$ once said after a sharp censure received from Mrs. Eddy: "That woman is either a saint or a devil: I'm sure I don't know which." "i The 
only thing of which anybody could be sure was that MIrs. Eddy was never to be taken on terms of equality by any one who crossed her path.

A determination unshaken through the years to win her point at any cost has brought its incidental disadvantages. People of fine sensibilities instinctively distrust the woman who airs her grievances in court. Mrs. Eddy has been in court too often for her own best interests. She has too often turned to strategy. And when the recent lawsuit was begun ii seemed at first to some as though there was to be at last ironical illustration of the words of Him who never went to law: "They that take the sword shall perish with the sword."

With the head of the Mother Church setting all through life a questionable example, it was natural for the directors of the Church to expose Christian Science to the humiliation of the other day when the Massachusetts Supreme Court decided that not merely had the directors in the building of the new church broken a legal contract but that they had also entered into a conspiracy with the labour union. The leader of a religious movement embarrasses the cause in unexpected ways by frequent lawsuits and by legal subterfuges. ${ }^{\text {is }}$ 
Love of money has been the root of many an ill in Mrs. Eddy's life. Spiritual gifts are too precious to be habitually prostituted to the accumulation of dollars even though the dollars are designed at last for the perpetuation of a church. It jars the spirit to turn from Mrs. Eddy's claim that Science and Health is "God's Book and He says give it at once to the people" ${ }^{49}$ to her suggestion of some years ago that it pays to be a Christian Scientist, to her sometime admission that Christian Science healers have made "their comfortable fortunes," and to her insistence on selling what she distinctly and steadily asserts is a spiritual necessity at a profit which has led in the case of corporations having a monopoly of the physical necessities of life to government investigation and universal reprobration. To have a fortune of admittedly about a million dollars accruing largely from the sale of a Book of Revelation which contains " nothing of human opinion" ${ }^{50}$ and yet for years to evade one's proportionate share of taxpaying, even though one gives back in other ways large sums to the community in which one lives, is to put too great a strain on public confidence.

But Mrs. Eddy's heaviest handicap has been her habitual sense of blamelessness. To claim 
inerrancy in judgment would be incredible enough. To claim, besides, always to have been correct in conduct is to overtax credulity. To profess to be, in a unique sense, of "divine origin," to be one with God in authorship, to be " only a scribe echoing the harmonies of heaven," to have a revelation " higher, clearer, and more permanent" than Jesus had, and steadily to deny in the face of every fact that she has ever been at fault in all the many difficulties she has had with others is to invite an analogy to Jesus which her record cannot stand. If only her family had found some fault with her, one would remember that the relatives of Jesus never took Him at his proper valuation. If only the clergy and the doctors had been scandalised by Mrs. Eddy's words and works, one would instinctively recall that it was the common people who heard Jesus gladly. But, unhappily, those who have been most severe on Mrs. Eddy all these years have been her own familiar friends, even her disciples chosen by her own free will, from the days when Mrs. Crosby, as she still admits. found pleasure in her company till not many years ago when Mrs. Eddy learned how to bind disciples to her with hoops of steel by assuring them a comfortable income while they practise their discipleship. 
Among the twelve there was one Judas, only one. It has been the lament of Mrs. Eddy's long career, especially before she moved to Concord, that there have been many Judases among her twelve. Jesus let his solitary Judas go out into the night and into the lasting detestation of the world without a word of execration. As Judas after Judas has forsaken Mrs. Eddy's communion, he has gone out, with infrequent exceptions, into the daylight of a friendly world sometimes to be followed through long years by Mrs. Eddy's fiery fulminations. How could it be otherwise with thirty-six of those nearest to her and most prominent withdrawing at one time after planning first to expel her from her church? ${ }^{51}$ If now in the fulness of her fame she would, like the great and good of ages past, acknowledge that she has not always had the right of it in all the strained relationships of life, particularly in the Quimby controversy, the voice of criticism would even now, though late, lose its sharpness, her reputation for generosity would be enhanced, and the golden thread, which runs through the strange pattern of her long career, would be more evident. But so long as she continues to inquire-as she did on August 25th ${ }^{52}$ — "Have 
I ever injured any one?" inviting thus the still unanswered challenge of the Han of $\mathrm{Naz}^{-}$ areth "Which of you convinceth me of sin?", only those can find her faultless who doubt the infallibility of that intuition which, she says, enables her to "discern in the human mind thoughts, motives, and purposes" or who under her spell are blind to the indisputable fact that many a disciple Mrs. Eddy to-day regards as a Judas has gone out from her because the disillusionment of close relationship with her or intimate acquaintance with her theory has disclosed the arrant folly of building any house upon the sand.

Mrs. Eddy will be judged in years to come not by her authorship, nor by the efficient organisation she has built up, but by her daily life along the past now lit at last by information. Ambition, avarice, love of fame and power may have their place in the career of a Wolsey, an Elizabeth, a Richelieu, and a Napoleon. In the life of a true religious leader, they have no proper place, and after Mrs. Eddy's death has broken the spell of "the grand old hypnotist," ${ }^{53}$ the world will see her as she is with all her faults as well as all her virtues, to which those nearest her bear constant witness. 


\section{CHAPTER V}

\section{THE PHILOSOPHY}

A Phase of Idealism-Mrs. Eddy Makes a "Revelation" of it-The Battle Cry of Christian Science-The Question of Reality-Christian Science neither Christian nor Scientific-The Practical ObjectionDifficulties of Apologists-Soul Senses-Mrs. Eddy's Isolation-An Unanswerable Criticism-No Room for Evolution-A Grave Indictment-Timely Illustrations of its Philosophical Anarchy.

\section{THE philosophy of Christian Science is} not difficult to state. It is merely a distinctive form of idealism. It is, in plain words, the theory, almost as old as man, that there is no reality save thought. India had the general idea before ever Gautama took his seat beneath the bo-tree. Democritus of Abdera as early as 430 B.c. remarked: "Man lives plunged in a world of illusion and of deceptive forms which the vulgar take for reality." Plato aroused a thoughtful interest in it among the metaphysical. The ZendAvesta is tinged with idealism. The Neo- 
Platonists made much of it in the early Christian centuries.

Bishop Berkeley, without denying the external world which we know, gave it a new vogue two hundred years ago. Spinoza's "Universal Substance" is substantially Mrs. Eddy's "Infinite Mind." Kant went so far as to lay down the proposition that " the laws of nature which physical science studies are the creations of our own understanding, acting upon the data of the senses." Lotze said that "matter is nothing but an appearance for our perception." The Transcendentalists were wont to speak of " the supremacy of mind over matter," and Emerson could on occasion sing:

"Out of thought's interior sphere These wonders rose in upper air."

But none of them ever dreamed of doing what Mrs. Eddy has accomplished in a single generation, making the philosophy of idealism in the minds of thousands a revelation handed down from heaven at a definite time and place, and the basis of a new and startling faith.

The one reality, says Mrs. Eddy, is God, whose other name is Mind or Spirit. "God is All-in-all." "All is infinite Mind and its infinite manifestation." "Matter is unknown in the Universe of Mind." "What seems to 
be matter is a mortal, material sense of that which is spiritual and perfect." " Matter and mortal body are the illusions of human belief which seem to appear and disappear to mortal sense alone." 1

One may agree or disagree with Mrs. Eddy, but one can not in this case fail to understand her meaning. She means exactly what she says, that matter has no real existence.

Before Mrs. Eddy's day, metaphysical discussion of the nature of the universe was regarded as mere theorising. It was academic; it smelt of the lamp. It was for the class-room and the seminar. It was not brought out into the open. No one essayed to reduce it to the terms of everyday experience. The utmost that even Hegel, most inclusive of all metaphysical idealists, set the idealist doing was to teach the world to understand itself, not to reform itself, according to philosophy.

Not so Mrs. Eddy. She would turn theory into practice. She would have her followers live up to her philosophy. Though once she does advise them to " emerge gently from matter into spirit," ${ }^{2}$ ordinarily, she would have them all behave as though there were no matter. Science and Health is one long battle cry to go forth in the spirit's might and put 
to rout the things men falsely fancy that they see, hear, touch, taste, and smell. Mrs. Eddy's ardent understudies crack their whips at the recalcitrant. Mr. Mosley says: "What God sees once he sees for all eternity, and sees as perfect as well as perfectly." 3 Mr. Farlow bids them to believe that "the demands of truth are that we shall at once be all that God would have us." 4 And Mrs. Eddy, for the encouragement of the faint-hearted who find matter a stubborn fact, indissoluble even in the crucible of Christian Science, pleads guilty at one time or another to having raised the dead, " brought out one apple blossom on an apple tree in January when the ground was covered with snow. And in Lynn demonstrated in the floral line some such small things." 5

Mrs. Eddy is far-sighted. She sees that the differentiate of her philosophy is its immediate availability in the world-struggle with $\sin$ and pain. She realises what many of her followers do not seem to realise, that it is the possible practicability of her idealism which enables it to challenge the attention of the world. She understands what even some of her official spokesmen give evidence of late of misapprehending, that to stand the strain of criticism, growing every year more trenchant 
the entire philosophy of Christian Science must abide by its obvious meaning without such qualification as one finds in Human Life for August.

Make it, like all other forms of idealism, merely speculation, and Christian Science becomes at once much ado about nothing. Regard it as logomachy and Mrs. Eddy takes her place, the only woman, in the long line of the bespectacled philosophers who have speculated to little purpose on the evolution of human thought. Divorce it like its fellow systems from daily living, and Christian Science will shrivel up to a brief paragraph in the Encyclopeedia Britannica.

This is the end, and there is no other, of all the tangled threads of Christian Science metaphysics which many a critic has endeavoured to untangle only to entangle them the more. This is the end the reader is to seize and gently pull if he would see the tangles disappear and the threads all lengthen out to one.

Then he will clearly apprehend why Christian Science is something wholly different in its philosophy from historic Christianity, which looks out, on the entire sum of facts, in all the reality with which they enter into our vital experiences. It sees the solid earth in its undeniable 
activity. It sees humanity in its unmistakable flesh and blood. It sees a vast physical universe spreading away into illimitable regions of space and time, moving under inexorable laws, held together into a single ordered mass, by the stress of co-ordinated forces. All this it sees, it accepts. It denies nothing, it refuses nothing. Whatever a valid experience ratifies, this is, for it, real. ${ }^{6}$

Historic Christianity accepts things as they are, and is still as idealistic as Christian Science. Things may have all the objectivity they seem to have and yet be forms of thought constructed by the mind and needed for the mind to work with and to work upon. Things may respond to all the tests the senses make and still be but expressions of the Universal Mind. There is no reason in the nature of the case why God, who is all Spirit and all Mind, must be limited in His range of choice of spirit forms. There is, at any rate, no philosophical necessity for finiteness to set metes and bounds to Infinitude and presuming upon the possession of spiritual senses, decide offhand what Infinitude must always do. Hamlet's word to Horatio is worthy the consideration also of the Christian Scientist:

"There are more things in heaven and earth, Horatio,

Than are dreamt of in your philosophy." 
The reader will apprehend, besides, why Christian Science is not really scientific. Science has no place for the finality that Mrs. Eddy has always claimed for her revelation of 1866 but has been disproving all these years by the continuous revision ${ }^{7}$ of her monumental book. Science recognises no such principle as Mr. Farlow would establish in his exhortation to become " at once all that God would have us"; for the essence of science is the gradual development for which evolution stands and which Jesus illustrated in his words, "first the blade, then the ear; after that the full corn in the ear." And those who would be Christian Scientists and true scientists at one and the same time may well regard the godly counsel of Sir Oliver Lodge: "if they will let go their anchorage, and sail on in a spirit of fearless faith, they will find an abundant reward, by attaining a deeper insight into the Divine Nature, and a wider and brighter outlook over the destiny of man." s

But what is the objection to Mrs. Eddy's theory that the one absolute God, who is omnipotence, truth, justice, love, has so constructed us that we see nothing which we think we see, that through no fault of our own we seem to be involved in a universal lie which 
Mrs. Eddy has built up a church to dissipate? The objection is manifestly this, that while we all may have one opinion or another about the composition of the universe, while many of us may hold with her to some form of idealism, while some of us may agree with her that spirit and not matter is both original and ultimate in the universe, we have each day to act as though matter existed.

For all practical purposes in the action or in the life of man, matter does exist. Bridgebuilding, house-building, nation-building, prove it to be no figment of imagination. We may all agree to agree with Mrs. Eddy that there is no matter, that matter is an idle dream. But our very agreement makes matter cease to be a dream. For as Kant long since observed: "A dream which all dream together, and which all must dream, is not a dream but a reality."

There are signs of late that some of Mrs. Eddy's recognised interpreters are uneasy at the turn the argument is taking at the hands of critics. Mr. Farlow went the length three years ago, of admitting that "Christian Science includes not only a presentation of the true spiritual state which is to be attained, but also a wise consideration and disposition of our 
present erroneous material condition. Call them what we please-delusions or realitieswe find ourselves confronted," he admits, "with limitations, discords, and evils-things which can not be ignored." ${ }^{9}$ Only the other day, he was at great pains to explain in reply to a sermon preached, April 22, 1907, in Indianapolis-for Mr. Farlow's watchful eye notes every criticism press and pulpit the land over offer his cause-that Christian Science "does not deny that pain and sin are real to material sense." Another of Mrs. Eddy's official interpreters, Mr. Bicknell Young, goes a little farther. He said, October 8, 1906, in Springfield, Massachusetts, that Christian Scientists in general do not deny the reality of things. "They affirm," he says, "the eternal existence of all things."

And so Mrs. Eddy's thesis of the unreality of matter would seem to be wounded in the house of its friends. But the hurt is only in the seeming. Neither means what his words imply to those uninitiated in Christian Science dialectics. Each seizes on a word which everybody understands generically and gives to it specialised significance. Each has in mind a subtle distinction between reality and actuality which people never make in ordinary discourse. 


\section{The Philosophy}

Each gives to reality the spiritual meaning which is but one of many meanings it may have, and when using it of matter thinks of matter not as matter is to ordinary minds but as it is to Christian Scientists,-- spirit and not matter.

To the average man anything is real of which his everyday experience gives valid testimony. Anything is real to him which cannot be explained away, which stays where it is put in time or space, which everybody accepts in the same sense as anybody. When, therefore, Mr. Young and Mr. Farlow begin these days to talk of things as though things were real, the average man takes notice and begins to think he apprehends. But just as apprehension, happy and expectant, passes into satisfying comprehension, Mr. Farlow disappears in a mist of Mrs. Eddy's making about the difference between the senses of the body and the senses of the mind, and Mr. Young resolves "things into thoughts" existent only in the mind of God. And so, confused, and dazed, the uninitiated in Christian Science metaphysics are led round by a back way once more into Mrs. Eddy's main travelled road of the " unreality of things."

Now one of two things is irrefutably true: 
either Christian Science spokesmen, in order to deceive the unwary and untrained, purposely argue in a circle, or else they are trying to account for themselves in a situation in which there are spiritual elements playing round them which they do not understand and which therefore they cannot make quite clear to others. Personally, I would gladly believe the latter of them. But I cannot understand why through the words and writings of Christian Scientists often ring impeachments of the sincerity, intelligence, and studiousness of those outside the fold who want to know the truth, whatever it may be, about the faith and its founder, and who intend, at whatever cost, to have their questions answered or else to know the reason why.

But Mrs. Eddy and her spokesmen hint that the real reason why we do not see things as they see them as thoughts in the Mind of God is that we lack what they have-Soul senses, Spirit senses, Mind senses.

What we term the five physical senses [Mrs. Eddy states], are simply beliefs of mortal mind ... the avenues and instruments of human error, which correspond with it. . . Christian Science sustains, with immortal proof, the impossibility of any material sense, and defines these so-called senses as mortal beliefs, whose testimony can neither be true 
of man nor his Maker. . . . Mind alone possesses all faculties, perception, and comprehension; therefore mental endowments are not at the mercy of organisation and decomposition. Otherwise the very worms could unfashion man. If it were possible for the real senses of man to be injured, soul could reproduce them in all their perfection; but they cannot be disturbed, since they exist as Mind, not matter. . . Neither age nor accident can interfere with the Soul's senses and there are no other real senses. ${ }^{10}$

Here, at last, one is inclined to make the frank admission that Mrs. Eddy has had something very like a revelation. But no. Soul senses are old friends. Kant knew them. Emerson's address on "Nature" in 1838 led to their adequate discussion. ${ }^{11}$ Quimby was familiar with them; for in a manuscript the author has seen, dated March, 1861, a year and a half before Mrs. Eddy paid her first visit to Quimby, he speaks of man's true senses as "spiritual" and potentially free from the body. ${ }^{12}$ In the manuscript, also, which Mrs. Eddy used at Stoughton and attributed to Quimby there is a paragraph about soul senses. And so we find Mr's. Eddy once more in the wake of P. P. Quimby, learning after him, probably from him in one of their many talks, another of the essentials to her theory. 
But what does Mrs. Eddy mean by soul senses? She means evidently spiritual intuitions: Why not, then, say so frankly? Why invent a new vocabulary when the old is adequate? Why not speak plain English like the rest of us? Why write like the young student in the theological seminary, who brought to his instructor an essay on the Book of Exodus in which he said, "In the midst of all this tumult the son of Amram stood unmoved"? "Whom do you mean," inquired the instructor, "by the son of Amram?" "I mean Moses, sir," was the reply. "Well, if you mean Moses why do you not say Moses?"

Is there no one bold enough to point out to Mrs. Eddy the absurdity of claiming that the race's spiritual intuitions are given to the Christian Scientists alone? Is there no one brave enough to remind her that four years before her book appeared Professor Tyndall was showing in his essay on The Scientific Uses of the Imagination how helpful insight is to science? Is there no one venturesome enough to recall to her memory that ten years before twenty-six of her admiring friends invited her to start a church in Boston and become its preacher, Phillips Brooks began at Trinity Church, scarcely more than a stone's throw 
from Mrs. Eddy's, that prophetic ministry which for many years was to the intuitions of countless thousands a continuous unveiling of the glories that shall be in heaven and earth? Is there no one divinely daring enough to teach her the comprehensive truth that all men being sons of God have the spiritual senses Mrs. Eddy talks so much about, and use them not to deny that there is such a thing as matter, but to transfigure and suffuse and make sacramental this matter which our spirit tabernacles in until " our flesh being subdued to the Spirit, we may ever obey Thy Godly motions in righteousness, and true holiness, to thy honour and glory who livest and reignest with the Father and the Holy Ghost, one God, world without end?" 13

It is so pathetic. Shut off from that world of sense which she vows does not exist, an aged woman who has had no superior among the women of recent times in the power to impress herself upon the age in which she lives treads round and round the narrow circle of her vain delusion that things are not, and yet for practical purposes they must be for a while at least, denying the existence of the comfortable house she lives in and yet is willing to live in until she dies, disputing the materiality 
of the coal that keeps her warm even though one of her disciples does admit that possibly it is real as long as the body it protects from the New England blasts seems to be, denying that "food is what sustains life" and yet of course indulging just as usual in her tea and toast and comforting herself with the reflection that it would be "foolish to stop eating until we gain more goodness," disavowing if she is truly logical that the monumental book exists, the sale of which at a price prohibitive to the poor has lifted her from poverty and placed her in the list of millionaires, and yet issuing the following instructions to her followers: "It shall be the duty of all Christian Scientists to circulate and to sell as many of these books [she refers also to her other books] as they can. If a member of the First Church of Christ, Scientist, shall fail to obey this injunction it will render him liable to lose his membership in this church." 14

It is more pathetic yet to turn from Mr. Farlow's earnest effort to square Christian Science with common sense in his admission that there are "things which cannot be ignored," and from Mr. Young's strange dialectic that Christian Scientists do not "deny the reality of things," to Mrs. Eddy's cruel, 
crushing, and conclusive sentence that "nothing possesses reality or existence except God." ${ }^{15}$ Of Mrs. Eddy and her loyal interpreters one is compelled to observe in calm and altogether kindly mood that, wholly apart from the merits and demerits of the cause they represent, "They cannot go on forever standing on one leg, or sitting without a chair, or walking with their feet tied, or grazing like the stags of Tityrus in the air." ${ }^{16}$ They must get together and keep together in the public mind if they would win the world to Christian Science.

There is one criticism of the philosophy of Christian Science to which no answer can be given. With the rest of us, Mrs. Eddy agrees that God is infinite. Being infinite, God is, in the nature of the case, unbounded by the limitations which time sets to our finiteness. God is timeless, and the psalmist therefore spoke well within the truth when he remarked that "A thousand years in Thy sight are but as yesterday." So careless is God of time that He takes a summer for the painting of the petal of the rose, ten thousand years or more to make a ton of coal, and no one knows how many million years to make man out of primordial protoplasm. 
It would be, perhaps, enough to prove my point were I to remind the reader that a revelation which, like Mrs. Eddy's, purports to cover every human interest, leaves no room for the thought of evolution. But I would take no advantage. I turn rather to the efforts made in recent years to explain away Mrs. Eddy's earlier claims for both originality and finality in the revelation she received. One instance is adequately illustrative. Mr. Farlow incidently admits, even in the face of Mrs. Eddy's frequent hints that between her and Christ there has been no historic link, that possibly there have been sages before the sage of Pleasant View, and that while Christian Science is " the direct emanation of the Divine intelligence as opposed to mere belief, yet its advent has been the result of development." ${ }^{17}$ But set no store by such admissions. Mr. Farlow follows Mrs. Eddy all the way even when his words would sometimes seem to lead another way. And to know the attitude of Christian Science toward evolution we must turn to Mrs. Eddy before we listen to her representatives.

Mrs. Eddy does say:

Perfection is seen and acknowledged only by degrees, in the midst of imperfection. The ages must slowly work up to it. How long it must be before 
we arrive at the demonstration of Scientific Being, no man knoweth, -not even the Son, but the Father; but one thing is certain, that error will continue its delusions until the final goal of gladness is assiduously earned and won. ${ }^{18}$

This looks like evolution, but it is not evolution. The process to which she refers is intellectual, not cosmic. It is nothing but a rather turgid statement that it will take a while to convert all the world to Christian Science,an obvious truth.

At a time when modification of the views of Darwin and Weismann has not weakened but rather strengthened the fundamental concept of evolution, Mrs. Eddy goes merrily along her way disclosing in such words as these her ignorance of the very alphabet of evolution: "Theorising about man's development from mushrooms to monkeys and from monkeys to men, amounts to nothing in the right direction, and very much in the wrong." 19

It would not be fair, however, to leave this aspect of our theme without an effort to find in Mrs. Eddy's entourage some who know more than she concerning erolution. Mr. Joel Rufus Mosley is a young man. He has had in Chicago, Harvard, and Heidelberg training in philosophy. He writes with charm and 
clearness, and his writings are gladly read. He tells us, in The Cosmopolitan for July, 1907 , that

Christian Science reveals that, since God is above the finite sense of time and space and all limitations of ignorance and evil, since he is unchanging in his perfection of being, action, and thought, whatever he sees once, he sees forever. The universe, including man, is, therefore, always perfect in the mind of God; as God made it, sustains it, sees it, as it really exists.

This means, if it means anything, that there is in the Christian Science scheme, no place for the evolution of the universe. Others, but not Christian Scientists, may therefore sing:

" A fire mist and a planet, a crystal and a cell;

A jellyfish and saurian, and caves where the care men dwell,

Then a sense of law and beauty, and a face turned from the clod;

Some call it evolution, and others call it God."

But Christian Science has its mathematician as well as its philosopher. The First Reader of the Church at Concord, Professor Herman $\mathrm{S}$. Hering, was once a member of the mathematical staff of the Johns Hopkins University. $\mathrm{He}$, therefore, should have working knowledge of the theory of evolution, and he says: 
It is claimed by some opponents that because Christian Scientists do not walk on the water, turn water into wine, multiply loaves and fishes, as did Jesus, and because they still have to do with matter at every turn, the doctrines of Christian Science, especially that of the unreality of matter, must be fallacious. Such an argument is like that which declares that because a schoolboy, who is just learning to add and subtract, cannot work out a problem in cube root, therefore the claims of greater possibilities in the science of mathematics are fallacious, and the schoolboy is badly deceived by the promise of being able eventually to solve such higher problems. ${ }^{20}$

These words, too, mean what they seem to mean, that evolution is not of matter but merely in the mind of those who are developing into consciousness of the unreality of matter. He says, too, as clearly as analogy can speak, that the time is coming when Christian Scientists will be able to whistle matter down the wind of life. It is all of a piece with Mr. Farlow's charge that we "at once be all that God would have us."

Denying, then, that God does follow the time-method of evolution in His work, insisting that because a thing is true it must neglect all time conditions except perhaps a few brief centuries, Christian Science sets itself against the biggest truth that man has ever learned 
about God's way of working. All these ages past, since Anaxagoras was trying to pluck out the secret of eclipses, and Job on his ashheap was justifying to himself the ways of God to man, men have meditated on the problems of the universe, assuming at the outset that however God may work, He must have all the time $\mathrm{He}$ wants to do His work.

As in these latter days men have come to see that God's method is invariably that of evolution and that therefore $\mathrm{He}$ takes more time than men once thought necessary for Him to do his work, men have developed such a respect for God's intelligence as in their ignorance they never had before. More than this, as normal men look back across the ages and see how slowly man has moved upward, working out the beast, and how quickly he has sometimes fallen back into his native beastliness, they grow righteously impatient with a scheme of human conduct which not only bids man act as if there were no past but also encourages him to ignore the plain dictates of that ordinary common sense to which society (as Christian Science will one day find to its discomfiture) sometimes owes more than to that mysterious second sight of which Mrs. Eddy speaks. 


\section{The Philosophy}

Mrs. Eddy may conceivably be right, the rest of us wrong; but it will take more than her "final revelation " of 1866 to induce representative men like Roosevelt and Taft, Eliot and Woodrow Wilson, Rainsford and George Gordon, to part with the accumulated knowledge of the past and to act as though the only things worth while had been revealed through the ambiguous pages of Science and Health. What Ancrum says to David Grieve, after his return from the far country, of defiance of conventions, can as well be said to-day to those who without a critical study of its philosophy build their house upon the sand of Christian Science:

All these centuries the human animal has fought with the human soul. And step by step the soul has registered her victories. She has won them only by feeling for the law and finding ituncovering, bringing into light, the firm rocks beneath her feet. And on these rocks she rears her landmarks-marriage, the family, the state, the Church. Neglect them, and you sink into the quagmire from which the soul of the race has been for generations struggling to save you. Dispute them! overthrow them,-yes, if you can! You have about as much chance with them as you have with the other facts and laws amid which you livephysical or chemical or biological. ${ }^{21}$ 
Along the way of evolution then, I draw to my indictment of Christian Science as a system of philosophy. I charge it with being nothing less than philosophical anarchy concealed beneath confusedness of thought and ambiguity of words. I charge it with proposing to the world a strange theory of life which, if lived up to, would break with the past in thought and action, disintegrate institutions built up at cost incredible of life and limb, and substitute for the order that has been secured in government, industry, morals, and religion, a state in which every man would do what seemed right in his own sight, wilfully regardless of the world experience, and what we have gained in ages past would, therefore, all be lost. $^{22}$

Is my indictment too severe? Think clearly. If Mrs. Eddy's theory that there is no matter in the universe is of more significance than any other idealistic theory it is because she would make haste to turn it into practice. Let us in fancy in a few imaginable. instances act upon her theory:

Coming up the street a moment since, I passed the police station. A useless burden on the city! Since there is nothing in the universe but God and God is good, there is no 


\section{The Philosophy}

criminal in jail or out. Or if there seems to be, the criminal is labouring under a delusion. "Through silent argument, convince the mortal of his mistake." ${ }^{23}$ That is Mrs. Eddy's way, if she is logical.

A block nearer I passed a drug store, whose contents Mrs. Eddy characterises as substitutes for the dignity and potency of divine mind, having for their purpose to "give death and the grave victory over man." 24 She brushes them away with the few words, "Mortal mind confers the only power a drug can ever possess," ${ }^{25}$ and casually suggests that her third husband was killed by "arsenical poisoning mentally administered." 26 For the doctors she has sharper words than for the druggists. "Diplomas," she reminds them, "no more confer a rightful power to kill people than does the assassin's steel." ${ }^{27}$ "Why support the popular systems of medicine," she inquires, "when the physician may be perchance an infidel, and lose ninety-and-nine patients while Christian Science cures its hundred?" 28 As though this were not enough, she adds that it is the doctors who "are flooding the world with diseases, because they are ignorant that the human mind and body are one." If this does not mean what it seems 
to mean what does it mean? And how can Miss Brookins say "Christian Scientists have no quarrel with the medical profession?" 29

A little nearer home I passed the Edwards Church, representing three centuries and more of struggle for the right to worship God as the individual pleases. Mrs. Eddy's writing is deficient in the saving grace of humour. But that she can indulge in irony is evident in these words about the churches and the clergy: "One of the forms of worship in Thibet is to carry a praying machine through the streets, and stop at the doors to earn a penny by grinding out a prayer; whereas civilisation pays for prayers by the clergy in lofty edifices. Is the difference very great after all?" ${ }_{30}$ Of all for which the Edwards Church stands, she can think of nothing more to say than "Worshipping through the medium of matter is Paganism." 31 "As in Jesus' days, tyranny and pride need to be whipped out of the temple, and humility and divine science welcomed in." ${ }^{32}$ This is the personal contribution of Mrs. Eddy to Christian unity.

And as to Smith College on my left, that is, according to Mrs. Eddy's theory, an evident absurdity. As we shall see later, sin and suffering are to Christian Scientists the special 
delusions that spring out of the great delusion that matter exists. If sin and suffering are delusions, history and literature, which are saturated with men's sins and sufferings, are deluding. What we call the sciences, too, we may neglect as " built on the false hypotheses that matter is its own lawgiver, that law is founded on material conditions." ${ }^{33}$ Yet the very buildings of Smith College are a proof made possible by that form of matter we call money that matter as well as spirit is, that God does work sacramentally, does reveal Himself to us through other books beside those of Mrs. Eddy, that in spite of Mrs. Eddy's dictum that "human thought never projected the least portion of true science," ${ }^{34}$ human thought is projecting every week in the laboratories of Smith College not Christian Science but true science. Mrs. Eddy would not tear the buildings down; there are, of course, according to her theory, no buildings to tear down. She suggests that to Christian Science be given the place in the curriculum which is now occupied by what she inaccurately calls "scholastic theology and physiology." 35 But she can scarcely hope that her suggestion will be promptly followed.

Now I submit in all sincerity that if this 
is not in essence anarchy, then there is no word in the English language with which to describe it.

If the reply is made that Mrs. Eddy would not apply her theory at once in every instance, that she has in late years advised her followers to obey the laws concerning contagious diseases, to leave surgery for a while to the doctors, to refrain from antagonism of the churches, and to send their children to school; that in nowise breaks the force of my contention. Whatever time allowance Mrs. Eddy permits is in direct contradiction of her thesis that there is no matter and that we err every time we act as though matter existed. If Mrs. Eddy were inclined to give to God all the time He needs and takes to work by the law of evolution which we see everywhere in operation, then Christian Science would simply be an interesting speculation bearing in no way on our every-day existence, in no way disturbing our relationship to church or to society, and scarcely worth expression in a new sect whose ultimate effect will be still further to postpone the happy day when we shall be "all of one heart and of one soul, united in one holy bond of truth and peace, of faith and charity." 36 


\section{CHAP'TER VI}

\section{THE RELIGION AND THEOLOGY}

God All-in-all-Principle not Personality-From Pantheism into Dualism-The Trinity-Christian Science is the Holy Spirit-The Incarnation an Exaggerated Nestorianism-Deifying Mrs. Eddy-Prayer Declaration not Petition-Abandoning the SacramentsSubstitution of a Breakfast for the Lord's SupperEvil no Real Existence-The Absurd Obsession of Animal Magnetism.

THE religion of Christian Science flows out of its philosophy. Lest I seem to have an eye more for faults than virtues, let me once again admit the merits of the system. Christian Science is in spite of every weakness a stout protest against materialism. It is, as Mr. Farnsworth truly says, "a religio-philosophical system appearing amidst an unphilosophical people of materialistic tendencies." To the philosophical materialism of those who, forgetting that there may be transmissive as well as productive functions, would make thought nothing but a function of the brain, Christian Science presents a vigorous if some- 
what incoherent denial. To the practical materialism that would leave God out of all account except on Sundays, Christian Science, though often strangely inconsistent, does steadily reply that "God is All-in-all" on week days as on Sunday. Christian Science does save many from their lower self. It does lead many to a larger faith in God and a closer walk with Him. It does impart to many a power and poise, serenity and joy they might have found before if they had sought them diligently in the church of their upbringing.

But as a religion-and, like Mrs. Eddy, we must use the term religion loosely to include theology-Christian Science has defects as fundamental as we found a while ago in its philosophy, and the first of these appears in the consideration of the Christian Science God.

Unity is the mind's first quest, and Mrs. Eddy is in line with other pilgrims of the Infinite in seeking unity. Unlike many of those, however, she has found what she has sought and has given it a name. "Principle" she calls it, and thus she answers the inquiry, "Is there more than one Principle?" "There is not. Principle is Divine, one Life, one Truth, one Love." " "Principle" is Mrs. Eddy's God and she has many synonyms for it: "God," 
“Mind," “Spirit,” “Soul,” “Substance," "Life," "Truth," “Love."

"Principle" in her theology gathers up into itself all the concepts we habitually associate with God, except the most important-personality. Before her book appeared in $\mathbf{1 8 7 5}$, she was telling her pupils, as two of them inform me, that they could make no progress till they had banished from their minds the thought of God as person. She instructed Richard Kennedy "to lay special stress," in healing patients, on the impersonality of God. This is the commanding thought that rings through the first chapter of the first edition of Science and Health, and in the third edition (1881) she writes with confident assurance that God "is not a person, God is Principle." ${ }^{2}$ In subsequent editions, while the word "person" occurs more frequently, it is on "Principle" that she chiefly depends. In $\mathrm{No}$ and $\boldsymbol{Y}$ es she says that "God is Love; and Love is Principle, not person." In Christian Science versus Pantheism, she draws such a sharp distinction between principle and personality as practically to eliminate personality from her idea of God. And Mr. Bicknell Young admits outright that " " personal' is one of the words that has hindered." 3 
In the interest of clear classification Mrs. Eddy finds a place among the idealistic pantheists. But she does not feel at home in such companionship. She thinks the prefix pan is too suggestive of the "mythological deity of that name." 4 She says that pantheism is annulled by Christian Science. And yet, when called upon to condense her system into an epigram she puts it thus, "God is All in all"; and then allows the sentence to be thus reversed, All in all is God. ${ }^{5}$ If this surprising proposition differs fundamentally from the test sentence of all pantheism, "God is all and all is God," common sense will be slow in making the discovery.

Mrs. Eddy explains in some detail that "God is not in the things He hath made." " But her explanation is not so anti-pantheistic as it seems. She is ever telling us that there are no things for God to be in. What seem to be such things are really $H$ is thoughts. "God is the all-inclusive One, Who with His thoughts, ideas, shadows, constitutes the Universe." " Even man has not the volition and the self-activity he thinks he possesses. He must will as God wills and act as God acts. He is nothing more than God's reflection in the looking-glass of Christian Science. When 


\section{The Religion and Theology}

he dares to think that he is more, he falls below the threshold of manhood and becomes what Mrs. Eddy calls with bated breath mere " mortal mind."

Try as she will, Mrs. Eddy never quite escapes from pantheism except to stumble into dualism by the creation of the independent activity of "mortal mind," which has no place in God because it is not good. Strange to say, Mrs. Eddy's philosopher-apologist, Mr. Mosley, takes the plunge along with her out of pantheism into dualism and pictures " the Immortal Mind and its universe of pure, perfect, and immortal ideas and the mortal mind and its seeming world of imperfections" as in direct opposition to each other. ${ }^{8}$

Mrs. Eddy's pantheism is unnecessary, and yet its origin was inevitable in a mind as literal as hers. Quimby often spoke of God as principle. In the Quimby manuscript from which for several years Mrs. Eddy taught, no sentence is more startling than the sentence "God is Principle." With her passion for the novel and bizarre Mrs. Eddy gave to the one new thought concerning God which she learned from Quimby an importance which it never had perhaps in Quimby's large and comprehensive mind. She made it central and cen- 
tripetal in her theology. She exploited it to the utmost without perceiving until recent years the plight in which it places her theology.

Once, in 1898, Mrs. Eddy hints that God may be personal "if the term personality, as applied to God, means infinite personality," and Mr. Farlow in 1907 assures the Rev. Edgar P. Hill that Mrs. Eddy does believe that "God is person in the infinite sense." 9

But our difficulties multiply. For more than thirty years Mrs. Eddy has been solemnly asserting that in 1866 she received a "final ${ }^{10}$ revelation." Now this "final revelation," which was finally as well as first expressed in 1875, in Science and Health, is saturated with the thought that God is not a person. In the very first chapter we are informed that " God is Principle, not person,” that Jesus preached the impersonality of God, that it was the error of believing in the personality of God that crucified Jesus, that the trouble with conventional Christianity to-day is that it makes God a person and that because it "starts from person, instead of Principle, it is not the truth," and that our duty in the premises is to base our opinions on principle and not person.

But if God was "not person" in $1875 \mathrm{He}$ is " not person" now. Mrs. Eddy can not 
make God person now without revision of her "final revelation" and a final revelation revised is no final revelation. Can it be that Mrs. Eddy's understudies are engaged in the revision of the revelation she received in 1866 ? These words from the earnest pen of Mr. Mattox would seem to point that way: "Naturally, with the progress of information and the development of her understanding, she might be expected to amend or modify her views." 11 Why "naturally"? If Science and Health is to be so amended year by year as to contradict one year what it said in earlier years, then it will take its place among the books of mortal mind whose value is determined by intrinsic worth and not by "final revelation."

If Mrs. Eddy believes in 1907 that which in 1875 she denied, that God is person in any sense whatever, the way to make clear her change of heart is not by reading into principle, which she usually introduces with a capital letter, the self-conscious content of personality, which she seldom or never introduces with a capital, but by rewriting the text-book of Christian Science in the interest of personality. She must stop speaking of "Principle alone" ${ }^{12}$ as reforming the sinner and healing the sick. She must allow some 
place for pleading as well as declaration in Christian Science prayer. She must cease to picture Christ as a bare idea in the Man of Galilee; ${ }^{13}$ and she must altogether revise this crude conception which she offers of the Trinity: "Life, Truth, and Love constitute the triune person called God,- - that is, the triply divine Principle, Love. They represent a trinity in unity, three in one,- - the same in essence, though multiform in office: God the Father; Christ the spiritual idea of sonship; divine Science, or the Holy Comforter. These three express in divine Science the threefold, essential nature of the infinite. They also indicate the divine Principle of scientific being, the intelligent relation of God to man and the universe." 14

Mrs. Eddy has made many claims for Christian Science, but this, that Christian Science is the Holy Spirit, overtops them all. It puts too heavy a strain upon credulity. And Dr. Fluno does not lighten the strain for ordinary Christians, wont to think that according to promise Jesus sent the Comforter to His bereaved disciples, by making what must seem to many the irreverent suggestion that "a woman . . . brought it to the world." 15

Concerning the Incarnation, Mrs. Eddy 
thinks more loosely than usual. The early Church was ever trying to determine how Jesus could be at the same time God and man. The necessity to exclude dualism from all thought about the personality of Jesus, and to establish for all time his oneness, was keenly felt. The early councils at Nicra, Constantinople, Ephesus, and Chalcedon were called for the consideration and determination of one aspect or another of this question. But of these and of their significance Mrs. Eddy apparently has no knowledge. As though the Council of Ephesus had not met in 431, she flings the Christian Science banner to the breeze of an exaggerated Nestorianism. She writes, "Jesus is the human man and Christ is the divine, hence the duality of Jesus, the Christ." 16

Whence did she get this heresy? Was it a feature of the "final revelation" she received in 1866? Evidently she would have us so believe. Christian Science as a whole dates, she says, from that experience. But before we put the subject out of mind, we turn back again to Quimby and his views.

What was Quimby's idea of Jesus Christ? The Quimby manuscript from which for many years Mrs. Eddy taught is not so clear about 
the Incarnation as concerning God. It yields, however, these two striking sentences: "Jesus was the name of a man and Christ was the truth." "Christ was the Wisdom that knew Truth dwelt not in opinion." But, fortunately, there are other Quimby sources. In the first volume of the Quimby manuscripts, dated April, 1860, two and a half years before Mrs. Eddy's first visit to her healerteacher, I found the idea first mentioned. A year later, in 1861, Quimby wrote that Jesus "separated himself as Jesus the man of opinions from Christ the scientific man." Again, in an article on the senses, he inquires: "Are our senses mind? I answer, No. . . . Mind and senses are as distinct as light and darkness, and the same distinction holds good in wisdom and knowledge, Jesus and Christ. Christ, wisdom, and (spiritual) senses are synonymous. So likewise are Jesus, knowledge, and mind." ${ }^{17}$

Here is Mrs. Eddy's dualistic conception of the Incarnation presented as clearly as she herself has ever stated it. The question, therefore, instantly arises, is this a case of literary parallelism? Parallelisms are not uncommon. They occur, however, so often between Mrs. Eddy and Quimby that the reader is by 
this time perhaps as sensitive to them as is the present writer. Instinctively, with each successive stage of the unfolding of Mrs. Eddy's theology, he looks for another parallelism, and he seldom looks in vain. The Mrs. Eddy of 1862, who in other instances contradicts the Mrs. Eddy of 1907, once more resolves our difficulty. In the very letter to the Portland Courier in which she hints that it is the Christ in Dr. Quimby which enables him to heal, she refers to "P. P. Quimby's theory of Christ (not Jesus)" 18 and proves conclusively that she understands it by professing the willingness and ability to furnish additional information on the subject. And so once more her Pauline claim that "I neither received it of man, neither was I taught it, but by the revelation of Jesus Christ," fades out before a fact. ${ }^{19}$

Mrs. Eddy is not ummindful of the problems raised by her dualistic theory, derived from Quimby. She justifies it thus: "The divine origin of Jesus gave him more than human power." ${ }^{20}$ At the same time she reminds us that Jesus was not one with the Father, that " the Lamb slain from the foundation of the world" was slain only in man's mind, not God's, and she finally disposes of the question in these easy words: "This dual personality, 
of the unseen and the seen, the spiritual and material, the Christ and Jesus, continued until the Master's ascension; when the human, the corporeal concept or Jesus disappeared; while his invisible self, or Christ, continued to exist in the eternal order of Divine Science." ${ }^{21}$

Mrs. Eddy's followers, however, see no problems. They see only her solution of them. 'They go along the course of Christian Science, belated Nestorians, holding to a dualism discarded by the Christian Church fifteen hundred years ago. Before me as I write there lie in manuscript the lecture notes of a Christian Science teacher of some fifteen years ago in which I find these unexpected words: "Jesus of Nazareth is often mistaken for the real Christ." Coming one Sunday morning from a service in the mother Church in Boston, I picked up on the street a stray leaf from an unknown student's Quarterly, and on the margin opposite the lesson for February 24th I found this pencilled comment: "Jesus, the human man; Christ, God's spiritual idea." The prophet and the people are one in this as in all other things in Christian Science, and when they speak of Christ they speak in the light of the following amazing sentence which Mrs. Eddy gives them: "The true Logos is demonstrably Christian Science.” 


\section{The Religion and Theology}

With the personality of Jesus Christ divided into a mere man called Jesus, who was not always wise and never had as high a revelation as Mrs. Eddy's, and a mere idea called Christ, who reappears to-day in Christian Science and no other faith, Mrs. Eddy shows a certain familiarity in dealing with the Incarnation which is disquieting even to the unconventional.

She begins with the assertion that she was not "apart from God" in writing her textbook. She calls it-and not the Bible"God's Book." She has on more than one occasion given the impression by a word or deed that she is in some mysterious way unlike the rest of us in kind as well as in degree. She once claims "divine origin." Those who are closest to her appear instinctively to take their cue from her. As early as 1882 the little band of Christian Scientists at Lynn were declaring that "unless we hear Her voice we do not hear His voice," and the Christian Science Sentinel, reporting Mrs. Eddy's address at the annual meeting of the mother Church in 1899, says, "it was not then Mrs. Eddy whom the people heard, but . . . the voice of God." 22

No later than last December its editor, Mr. Archibald McLellan, sent to her with a 
suggestive note the following quotation from Fiona MacLeod's The Isle of Dreams:

It is commonly said that, if he could be heard, none should write in advance of his times. That I do not believe. Only, it does not matter how few listen, I believe that we are close upon a great and deep spiritual change. I believe a new redemption is eren now conceived of the Divine Spirit in the human heart, that is itself as a woman, broken in dreams and yet sustained in faith, patient, long. suffering, looking towards home. I believe that though the Reign of Peace may be yet a long way off, it is drawing near, and that Who shall save us anew shall come divinely as a Woman, to save us as Christ saved but not as $\mathrm{He}$ did, to bring with her a sword. But whether this Divine woman, this Mary of so many passionate hopes and dreams, is to come through mortal birth, or as an immortal Breathing upon our souls, none can yet know. ${ }^{23}$

Years ago Mrs. Eddy was identifying herself with the "woman clothed with the sun" in the book of Revelation, and remarking that as Jesus represents "the fatherhood of God" so the woman is the "type of God's motherhood." 24 To Mr. Spofford she had already written that her revelation of God was " higher, clearer, and more permanent" than the Master's had been. In 1898 she passes on to this subtle explanation: 
"The impersonation of the spiritual idea had a brief history in the earthly life of our Master; but of his kingdom there shall be no end; for Christ, God's idea, will eventually rule all nations and peoples-imperatively, absolutely, finally-with Divine Science. This immaculate idea, represented first by man and last by woman, will baptize with fire." 25

While she has never said outright, perhaps, as has been claimed for her, that she is "the Way to God" and Jesus only "the Wayshower," ${ }^{26}$ Mrs. Eddy is over-fond of building up progressive series like the following: "John the Baptist, Jesus the Messiah, the Woman "type of God's motherhood." She is past-mistress in that art of irresponsible allusiveness which Newman had in mind in his description of the man "who never enunciates a truth without guarding himself against being supposed to exclude its contradictory." What could be more irresponsibly allusive than this?-_ No person can take the individual place of the Virgin Mary. No person can compass or fulfill the individual mission of Jesus of Nazareth. No person can take the place of the author of Science and Health, the discoverer and founder of Christian Science. Each individual must fill his own niche in time and eternity." 27 
What Mrs. Eddy's niche in time is to be, she says, "remains to be proved." She is more concerned, it seems, to carve out the niche she is to fill in all eternity, which, as she realises, includes time. She is making rapid progress in her ambitious task. She reports in $\mathbf{1 9 0 6}$ that God is " divine Principle-as Life, represented by the Father; as Truth, represented by the Son; as Love, represented by the Mother." 28

Discovering long ago that Mrs. Eddy likes to dwell upon the incarnation of the motherhood of God, that she had even suggested the idea in her version of the Lord's Prayer with its appalling substitution of "Our Father-Mother God" for "Our Father which art in heaven," Mrs. Eddy's followers began with one accord to call her "Mother." To hold the vantage ground thus gained in her progressive elevation, Mrs. Eddy, in the nineties, designated herself as "Mother Mary" and made it in a by-law of the mother Church "an indication of disrespect for their Pastor Emeritus, and unfitness to be a member of the Mother Church," for Christian Scicntists to give the title Mother to anybody else on earth except one's mother in the flesh. Everybody spoke of her as "Mother." She 
sometimes signed herself "Mother Mary." The President of the National Christian Science Association on one occasion said, "There is but one Moses, one Jesus; and there is but one Mary." 29

All this deifying went on not without some criticism even in the Christian Science camp. Mrs. Eddy, therefore, always watchful for any sign of disaffection, made at last one of her sweeping denials, as though facts could be denied, and added a new by-law in 1903 to her church Manual ordering the substitution of the word Leader for Mother in Christian Science terminology. ${ }^{30}$ Mark Twain's quaint suggestion that there would never have been any trouble had Mrs. Eddy signed her famous telegram "Mother Baker" and not "Nother Mary" lights up the entire situation. ${ }^{31}$ Mrs. Eddy did not want, and can not bear, to be regarded as an ordinary mother of her spiritual children. She craves, and she will have, a higher type of motherhood.

Under pressure, Mrs. Eddy has now and then repudiated the parallelism her words have constantly been tending to set up between herself and Christ. But here, again, facts are not to be dismissed by mere denial. They are too numerous and too indicative to be denied. 
Even in her early teaching days she fell instinctively into comparisons of herself and Jesus, and never to her own disparagement.

This is what she wrote in $\mathbf{1 8 7 7}$ to a favourite student:

I know the crucifiction of the one who presents Truth in its higher aspect will be this time through a bigger error, through mortal mind instead of its lower strata or matter, showing that the idea given of God this time is higher, clearer, and more permanent than before. My dear companion and fellow labourer in the Lord is grappling stronger than did Peter with the enemy, he would cut off their hands and ears; you dear student, are doubtless praying for me-and so the Modern Lawgiver is upheld for a time. ${ }^{32}$

If anything was needed to complete the parallelism between herself and Jesus it was furnished in the amusing comparison of her un-Petrine husband with the impetuous disciple who cut off the ear of Malchus when

"Out of the woods my Master came."

Mrs. Eddy loved, also, to play the rôle of the suffering Messiah, as though a system which has no room for suffering could need a suffering Messiah, and when she was ill or troubled, as frequently occurred, she was apt to remind her students that Jesus, too, was 
bruised for our transgressions and bore upon his shoulders the world pain. ${ }^{33}$

In 1899 the Christian Science Journal, which she then owned, distinctly made the claim, without rebuke from her, that Mrs. Eddy was the equal of Jesus, and offered elaborate proofs in confirmation of the same. ${ }^{3+}$ She has always had a liking for the words of Jesus in discussing her own personality, and she cannot, even in 1906, attempt the solution of the vexatious servant problem by making it obligatory on any Scientist designated by the Board to become her servant without adding, in the by-laws of her church, the reminder that "He that loveth father or mother more than me is not worthy of me." 35

In an illustrated book called Christ and Christmas, published by her in 1894, her parallelisms reach the climax of audacity. One picture represents Christ with a halo round his head raising the dead from a modern coffin. Another represents a woman with a halo round her head raising the sick from a bed. In a third picture the two are brought together, and there is a halo round each head. Jesus, seated on a stone, holds the woman's right hand while in her left she bears a scroll on which the words "Christian Science" ap- 
pear. The identity of the woman is not stated. Why should it be? The very arrangement of the hair suggests it. The following limp verse opposite the picture leaves nothing to imagination:

"As in Blessed Palestine's hour, so in our age 'T is the same hand unfolds His power and writes the page."

If the picture is not self-authenticating then the mystic words she wrote, when the usual criticism came, that "Scientists sometimes take things too seriously," ${ }^{36}$ and her withdrawal of the book from circulation until the storm was over, will suffice to convince everybody except those who can not be convinced.

But specific instances are not needed to inform the conscientious student of Christian Science literature that MIrs. Eddy holds herself in an unmatched relationship to Jesus Christ. The entire sweep of her teaching, the attitude toward her into which her followers intuitively drift, the progressive mariolatry steadily developing in spite of her transparent protests, and the painstaking efforts made till recently to conceal the infirmities of her advancing years, are sufficiently indicative. And if in spite of all appearances, as one near her has said, there is no warrant for the in- 


\section{The Religion and Theology}

evitable conclusion, the verdict, however well disposed the critic is, will be not unlike the homely verdict of the Western jury," "Not guilty, but don't do it again."

Whatever may be Mrs. Eddy's relationship to Jesus Christ, there is one respect in which she seems to set herself above Him. Jesus prayed as normal people pray. He prayed to God as though God were a person. He prayed to God as though God were His Father. He pleaded with Him for specific things, conditioning each prayer with its "if it be possible." He prayed in private and $\mathrm{He}$ prayed in public; and $\mathrm{He}$ taught His disciples a form of common prayer, the justification and illustration of all common prayer to-day. Mrs. Eddy accepts the fundamental principle of all Jesus' praying, that prayer is communion with God. But her acceptance is modified by the persistence and obtrusiveness of her pantheism.

How can one pray to Grod when one is not sure that God is personal? How can one pray to God when one believes that " prayer addressed to a person prevents our letting go of personality for the impersonal Spirit to whom all things are possible"? ${ }^{37}$ How can one pray to God when one holds that "the habit of pleading with the divine Mind, as one 
pleads with a human being, perpetuates the belief in God as humanly circumscribed, - an error which impedes spiritual growth"?

While the Christian Scientist is steadily moving away from the petitional element with all that it involves of personal relationship, a scientific Christian, like Sir Oliver Lodge, is ever drawing nearer to it with these words: " Through prayer we admit our dependence on a higher power, for existence and health and everything we possess; we are encouraged to ask for whatever we need, as children ask parents; and we inevitably cry for mercy and comfort in times of tribulation and anguish." ${ }_{38}$

Nowhere in Mrs. Eddy's treatment of the subject is there the Gethsemane element of "if it be possible." Audible prayer she reprehends. It imparts no understanding. It makes involuntary hypocrites. It brings no lasting benefit. "Lips must be mute and materialism silent, that man may have audience with Spirit, the divine Principle, Love, which destroys all error." 39

Prayer is reduced in Christian Science to mathematical exactness by the substitution of declaration for petition, and when Christian Science prayer is audible at all it is not prayer 


\section{The Religion and Theology}

but merely a declaration of the relationship of Principle (God) to its idea (man). Clearer than any definition Mrs. Eddy gives of Christian Science prayer, is one offered by her lecturer, Miss Brookins, in the sentence, "An habitual declaration of man's unity with the divine and inexhaustible Life, the real and indestructible Substance, the infinite and omnipotent Love, is the effectual prayer that availeth much, in that it heals and redeems the sin-sick and bodily infirm and casts out all manner of evil." 40

There is one barrier in the way of the Christian Science theory of prayer. The Lord's Prayer contains all the elements which Mrs. Eddy says prayer should not have. It was intended to be audible. At least it was in audible use in the public worship of the early Christians, who were within a generation of Christ's time. Nothing could be more certainly petitional than "Give us this day our daily bread." There is more than a suggestion of "if it be possible" in "Thy kingdom come." But Mrs. Eddy is not to be daunted. Careless of her tenses, she explains away the plain meaning the Lord's Prayer has had all through the centuries, commands her explanation to be used invariably with it at all Chris- 
tian Science services, and prints it thus in her text-book:

Our Father which art in heaven, Our Father-Hother God, all-harmonious,

Hallowed be Thy name. idorable One.

Thy kingdom come.

Thy kingdom is within us, Thou art ever-present.

Thy will be done in earth as it is in heaven.

Enable us to know, as in heaven, so on earth-God is omnipotent, supieme.

Give us this day our daily bread;

Give us grace for to-day; feed the famished affections;

And forgive us our debts, as we forgive our debtors.

And love is refleeted in love;

And lead us not into temptation, but deliver us from evil;

And God leadeth us not into temptation, but de-

livereth us from sin, diseasc and death.

For thine is the kingdom, and the power, and the glory, forever.

For God is infinite, all Pover, all Life, Truth, Love, over all, and All. ${ }^{41}$

To one outside the Christian Science fold it is refreshing to turn from such unreal and unwarranted exegesis to the explanation Sir Oliver Lodge, comprehensive equally in his Christianity and his science, gives of the 


\section{The Religion and Theology}

Lord's Prayer. He says that when we use it in these scientific days

we first attune our spirit to the consciousness of the Divine Fatherhood; trying to realise His infinite holiness as well as His loving-kindness, desiring that everything alien to His will should cease in our hearts and in the world, and longing for the establishment of the Kingdom of Heaven. Then we ask for the supply of the ordinary needs of existence, and for the forgiveness of our sins and shortcomings just as we pardon those who have hurt us. We pray to be kept from evil influences, and to be protected when they attack us. Finally, we repose in the might, majesty, and dominion of the Eternal Goodness. ${ }^{42}$

Surprising as is Mrs. Eddy's effort to make prayer nothing more than declaration, far more surprising is her treatment of the sacraments of Baptism and the Lord's Supper.

Christian people generally agree that a sacrament is "an outward and visible sign of an inward and spiritual grace." They accept literally Jesus' injunction to "teach all nations, baptising them," and St. Paul's testimony that

I have received of the Lord that which also I delivered unto you, That the Lord Jesus the same night in which he was betrayed took bread: And when he had given thanks, he brake it, and said, Take, eat: this is my body, which is broken for you: 
this do in remembrance of me. After the same manner also he took the cup, when he had supped, saying, This is the new testament in my blood: this do ye, as oft as ye drink it, in remembrance of me. ${ }^{43}$

Christians perpetuate the sacraments of Baptism and the Lord's Supper because they believe that in so doing they do the will of Jesus Christ.

Mrs. Eddy sees nothing in a sacrament save a Roman soldier's oath, and one authorised to speak for her assures us that she honours the sacrament apart from its material symbol, as though the symbol were not itself the sacrament. ${ }^{44}$

"Baptism," she says, "is a purification from all error." One student recalls how Mrs. Fddy once held a baptismal service without water, and no student, however earnestly he seeks, will ever find a font in any Christian Science church. ${ }^{45}$

The Lord's Supper she long ago dismissed as " a dead rite." ${ }^{46}$ She explains that Christ has come a second time in Christian Science and inquires, "If a friend be with us, why need we memorials of that friend?" The mother Church in Boston does have, not oftener than once a year, what Christian Scientists are pleased to call a "Silent Communion." But 
it has no actual relationship with the Lord's Supper. "Our Eucharist," says Mrs. Eddy, "is spiritual communion with the one God. Our bread 'which cometh down from heaven' is Truth. Our cup is the Cross: our wine the inspiration of Love." $4 \tau$

Worse than this, Mrs. Eddy calmly suggests the substitution of a breakfast for the historic Supper of the Christian Church. Read her amazing words: "What a contrast between our Lord's last supper and His last spiritual breakfast with His disciples in the bright morning hours, at the joyful meeting on the shore of the Galilean sea. . . . This spiritual meeting with our Lord, in the dawn of the new light, is the morning meal which Christian Scientists commemorate." ${ }^{48}$

Even Straus stopped short of substitution. He wrote, "Never at any time will it be possible to rise above Him or to imagine any one who should ever be equal with Him." And yet Mrs. Eddy, without training in textual criticism, ventures to dismiss the historic Supper which Jesus established if He established anything, and to substitute for it a breakfast $\mathrm{He}$ nowhere hints $\mathrm{He}$ wanted or intended to establish.

"The emphatic purpose of Christian Sci- 
ence," says its founder, "is the healing of $\sin$; and this task is a million times harder than the cure of disease." 49 St. Paul could bear his thorn in the flesh. He could even suffer fools gladly. But sin wrung from him the bitter cry, "O wretched man that I am. Who shall deliver me from the body of this death?" Whatever sin may be in metaphysics it is real enough in life. It gets up with us in the morning. It is at our elbow all day long. It goes to bed with us at night; sometimes to haunt our dreams. It is grimly real.

But what is $\sin$ in the catalogue of Christian Science? It is usually identified with evil. It " never did exist." It is the effect of error, and since error is the author of the unreal, sin, evil in general, is unreal. It bears " the same relation to good," says Mr. Farlow, "that darkness bears to light. The psalmist said 'The darkness and the light are both alike to thee.' This was equivalent to declaring that to the supreme intelligence there is no darkness; all is light. God is good omnipresent; hence there is no room for evil." 50

At this point, Christian Science comes closer possibly than elsewhere to the liberal thinking of to-day. That evil is unreal in the sense that it is not to last forever many hold 
outside of Christian Science. Mystics even back to Dionysius go all the way with Mrs. Eddy in denial that evil is, in any sense, real. Browning says, "The evil is null, is nought, is silence implying sound" ${ }^{51}$; and R. J. Campbell urges us to break the fetters of sin by "the reassertion of the universal life." 52

Christian Science finds its concept of evil in the fourth of Mrs. Eddy's fundamental propositions: "Life, God, omnipotent Good, deny death, evil, sin, disease." " ${ }_{53}$ In confirmation of this the Scriptures are invoked by Mr. Farlow. But as often happens when used as an arsenal from which to draw proof texts, the Scriptures are far from conclusive. If the psalmist thought, as Mr. Farlow says, that God did not create the darkness and the evil of the world, Isaiah disagrees with him. Isaiah puts into the mouth of God the words: "I form the light, and create the darkness: I make peace and create eril: I the Lord do all these things." If, as Mr. Farlow likes to tell us, after God had finished the creation of the world $\mathrm{He}$ "saw everything that he had made, and behold, it was very good," God would seem to have given recognition to the darkness, since $\mathrm{He}$ had, a while before, taken the trouble to " divide the light from the dark- 
ness." The time has long since gone for proving anything by proof texts. The whole sweep of the Bible has in these days to be regarded, and it is enough to say that the Bible as a whole speaks with uncertain voice as to the origin of evil..$^{54}$

Whether sin be philosophically real or not it is actual. Of the presence of sin in thought Mrs. Eddy is quite assured. She says the mind must be emptied of sin or sin will never cease, that to indulge in sin while asserting its unreality is a moral offence, that the victory over sin will not be won till we strip off its mask..$^{55}$ But if there is in any of her writings the instinctive recoil from the actuality of sin, I have failed to find it. In spite of the fact which the world has long since proved, that sin, whatever it may be in theory, is in practice " not a want of light but a neglect of light," ${ }_{56}$ Mrs. Eddy speaks thus her final word: "If proper ward were kept over that lazar-house. that dismal cell and slaughter-house of infamy, mortal mind, the broods of evil which infest it could be cleared out."

The characteristic weakness of Mrs. Eddy's theory of $\sin$ is not, however, her failure to speak clearly about the actuality of sin, nor yet her pantheistic tendency which many 
critics have observed to confuse moral distinctions. $^{57}$ It is rather her extraordinary attitude toward the will. The will to do the right and to leave undone the wrong has no place in the plan of Christian Science. It is, like sin, an illusion. Its exercise is "detrimental to health and integrity of purpose." It is " the motive-power of error." It " produces evil continually." Though she hints at a higher will on higher business bent, the will with her is ordinarily that awful thing she calls animal magnetism. ${ }^{58}$

Many pages in Science and Health are at first difficult to understand. Those which deal with animal magnetism are difficult also at last to understand. Quimby has no responsibility for them. IIad Mrs. Eddy possessed the knowledge she thought she had of Quimby she would never, as one of her old students writes me, have fallen into such an impossible conception. Had she even caught Quimby's wholesome spirit she could never have conjured up such a morbid explanation of her break with Kennedy and Spofford or dignified it into an actual doctrine in the third edition of her text-book. A student ventured once to suggest: "Don't you think the time has come to speak less of animal magnetism?" 
Whereat Mrs. Eddy sprang up from her desk and clapped her hands together, sharply crying, "Leave me at once." 59

There seems to be no adequate explanation of the strange hold her animal magnetism seems to have had on her. It might be called an obsession. Every religious leader is apt at some time to personalise the evil of the world. Nothing else will serve so many purposes. Years ago Mrs. Eddy found her devil. Her literary adviser in the eighties said, "Animal magnetism is her devil." Sometimes she calls it hypnotism, mesmerism, mortal mind, malicious animal magnetism as well as animal magnetism, and in her private correspondence she familiarly refers to it as "M. A. M."

The clearest account of it is given under the heading of "Mortal Mind." She says it has no real existence; it is nothing, while claiming to be something. And yet she admits it to be "an autocrat" and "the cause of organic disease." She says it "changes order into discord," "confers power on drugs," "produces false beliefs," " convulses matter," " counterfeits divine justice," " creates its own conditions," "fills creation full of nameless children," "fills man with pain," "impresses its thoughts on body," "makes Spirit noth- 
ing," " rules all that is mortal," "transfers its fears to other minds," and "seeks to kill his fellow-mortals, morally and physically." 60

If Mortal Mind does things so terrible, no wonder Mrs. Eddy calls it Satan. ${ }^{61}$ No wonder she has spent her life in mortal terror of it. No wonder she once wrote a student who, she feared, was criticising her, "Wont you exercise reason and let me live, or will you kill me? Your mind is just what has brought on my relapse." ${ }^{2} \quad$ No wonder she could bring herself a few years later to believe that her husband Dr. Eddy had been killed by " arsenical poison mentally administered," and that even a printing press might be put out of order by " M. A. M." No wonder her adopted son, Dr. Foster-Eddy, tells of days as dark and nights as black as those painted by Poe, when the unhappy woman fancied that evil minds were assailing her to her confusion and distress. No wonder that as recently as $\mathbf{1 9 0 0}$ she wrote him: "You are better removed from 'M. A. M.' in Boston." No wonder that her true son came away from his last meeting with her a few months ago impressed with the effect of the terrible obsession on her mind and soul and has since had evidence of her belief that "M. A. MI." is at the bottom of the late 
lawsuit and of the criticism to which she is in her old age exposed.

Stranger than Mrs. Eddy's situation is that of many of her followers who are troubled by the same obsession. I have talked with Christian Scientists, great and small, who seem more certain of the personality of " M. A. M." than of the personality of God. I know directly, and I know of, good people ill who charge the tardiness of their recovery to the "M. A. M." which they are sure that unbelievers send their way. Judge Clarkson of Omaha, Nebraska, left Christian Science because its "M. A. M." became unbearable. ${ }^{63}$ If Christian Science is to grow after Mrs. Eddy's death, her demonology, which is all her own and not Quimby's, must die with her. Otherwise it will drag the entire system up before that bar which no obsession ever yet has faced and lived, the bar of the universal sense of humour. ${ }^{64}$ 


\section{CHAPTER VII}

\section{CHRISTIAN SCIENCE HEAI.ING}

The Supreme Test of Christian Science-Mrs. Eddy's Claim that Christian Science Cures all Diseases-Her Followers' Attitude-Venturesome ExperimentsConcessions to Public Opinion-Inadequate Diagnoses -All Tests Declined-Mrs. Eddy's Attack upon the Doctors-Reply of Medicine and Surgery-Healing by Understanding of the Christian Science TheoryPractical Illustrations-Chemicalisation-Jesus' Way -Mental Healing through the Centuries-Pseudoscientific and True Scientific Mental Healing-Principle Common to Both-The Possibilities and Limitations of Suggestion-Christian Science Admits no Limitations-Consequent Need of State RegulationThe Duty to the Truth.

THOUGH the healing of the sinful may be, as Mrs. Eddy says, the supreme interest of Christian Science, the healing of the sick she makes its supreme test. She stakes her whole philosophy in fact upon her therapeutics. The central principle that "Mind is All-in- 
all " and that matter has no real existence is, we are assured, "demonstrated by healing the sick, and thus proven absolute and divine. This proof once seen, no other conclusion can be reached."

The critical student of the movement welcomes any test. Nothing else so simplifies a complex situation. And yet Mrs. Eddy's willingness to submit her philosophy to a therapeutic test argues a primitive conception of the relationship between philosophy and therapeutics. It suggests the Indian "medicine man" "demonstrating" 1 - a favourite word with savages as well as Christian Scientists-the truth of the impossible theology he holds, by noisily frightening the evil spirits out of the sick man.

But if Mrs. Eddy can make out a case for the unparalleled efficacy of Christian-Science healing, no matter what the facts may prove or fail to prove, every book on medicine and theology will be discredited. Every doctor will abandon his profession, to become possibly a Christian-Science healer. Every clergyman will leave his pulpit, possibly to seek a readership in Christian Science worship. And doctors and clergymen, with Mrs. Eddy in mind, will say to one another what the 


\section{Christian Science Healing}

Pharisees said among themselves of Jesus,

"Perceive ye how ye prevail nothing? behold, the world is gone after him."

What is Mrs. Eddy's case? She claims three things for Christian Science healing:

1. That it is "the most effective curative agent in medical practice."

2. That it is Jesus' way of healing.

3. That, abandoned in the early centuries by the Christian Church, it

a. was first revired by her in 1866, and,

b. is to-day employed by Christian Science alone.

Her first claim rests upon her general principle that "Mind is All-in-all." "Health," Mrs. Eddy says, "is not a condition of matter but of Mind; nor can the material senses bear reliable testimony on this subject. ... The divine Principle of Science, reversing the testimony of the physical senses, reveals man as harmoniously existent in Truth, which is the only basis of health; and thus Science ... heals the sick." 2

The principle is all-inclusire. If a man holds steadily to the belief that "Mind is Allin-all," if a man follows to the letter Mr. Farlow's counsel that "though the evidences of the senses may declare to the contrary we 
should still stick to the spiritual truth and should continue to denounce the false evidences," he is certain to get well, no matter what his illness may appear to be. Organic diseases, Mrs. Eddy tells us, she has cured " as readily as functional disease." She has "healed hopeless disease, and raised the dying to health and life." She has stopped the bleeding of a wound in her own arm. "I healed," she says, "consumption in its last stages that M. D.'s declared incurable, the lungs being mostly consumed. I healed malignant tubercular diphtheria. . . . I healed a cancer that had so eaten the flesh of the neck as to expose the jugular vein so that it stood out like a cord." 3

Following closely in the steps of Jesus, she promises her followers the power to duplicate her healing work. After a few lessons, they go forth accredited to heal all manner of diseases. Consumption, of course, they are to cure since there are no lungs to become tuberculous. Children's diseases, even though contagious, will prove tractable; for the mother's fears have brought on the disease. Small-pox is not difficult; "mortal mind, not matter, contains and carries infection." Leprosy is as easy to relieve as when Moses made his hand leprous 
and unleprous at will by Christian Science methods. Palsy yields at once on the discovery that "muscles have no power to be lost." Cancer cannot hold its own if the belief in it be blotted out by "such powerful eloquence as a legislator would employ to defeat the passage of an inhuman law." No fever can withstand the fearlessness of matter. Brain diseases, even in advanced stages, disappear before the understanding that "actual Mind" cannot be overworked. Malformed limbs and other troubles of the bones, being "as directly the action of mortal error as insanity," are scarcely worth regarding. If Christian Science were clearly understood, " the human limb would be replaced as readily as the lobster's claw,-not with an artificial limb, but with the genuine one." Practically every disease is covered and any possible omission would seem to be an inadvertence. ${ }^{4}$

Her followers have accepted all her claims with the same seriousness with which she has made them. Many of these her disciples have by personal experience illustrated, and other claims their observation has confirmed. Judge Hanna bears witness to Christian Science healing of cancers, consumption, and broken bones. Mr. Carol Norton adds to the list loco- 
motor ataxia, paresis, and Bright's disease. Judge Clifford P. Smith solemnly affirms that Christian Science has cured people of every kind of disease known to the practice of medicine, whether considered curable or incurable by that system. And even a magazine writer like William Allen Johnston is impressed with the voluminous evidences steadily accumulating of the therapeutic value of Christian Science. ${ }^{5}$

Healers trained by Mrs. Eddy or by her sanction have proved as daring as the founder of the system. One has endeavoured to lift the drooping head of a wilted rubber plant. Another has essayed to send out healing currents from the mental battery of Christian Science toward horses, cows, and dogs. Another reports the "good-sized cavity" of an aching tooth filled up by mental treatment " not with foreign substance, but the genuine, white and perfect." ${ }^{6}$

Mrs. Eddy herself gladly takes advantage of a dentist's offer of painless treatment of her teeth and gives the following ingenious reason why:

Bishop Berkeley and I agree that all is Mind. Then, consistently with this premise, the conclusion is, that if I employ a dental surgeon, and he believes 
that the extraction of a tooth is made easier by some application of means which he employs, and I object to the employment of this means, I have turned the dentist's mental protest against myself, he thinks I must suffer because his method is interfered with. Therefore, his mental force weighs against a painless operation, whereas it should be put into the same scale as mine, thus producing a painless operation as a logical result. ${ }^{7}$

Her accredited healers, encouraged by her statement that "Science can heal the sick who are absent from their healers, as well as those present, since space is no obstacle to mind," endeavour in their mental practice to eliminate all space conditions. ${ }^{8}$

Mrs. Eddy has learned prudence with the passing years. Without qualifying her assumption that the cure would always follow could conditions be controlled, she admits the temporary presence of unmanageable elements. Public opinion, which she calls mortal mind, is so certain, she remarks, that arsenic, and strychnine in sufficient doses will cause death, that in spite of himself a Christian Scientist may die in the fulness of his faith if a " dose of poison is swallowed through mistake. . . The result is controlled by the majority of opinions outside, not by the in- 
finitesimal minority of opinions in the sick chamber." ${ }^{9}$

For the same reason, though surgery was once, when Eve was excised out of Adam's side, altogether mental and "Christian Science is always the most skilful surgeon," it is better to leave surgery and the adjustment of broken bones and dislocations, to the fingers of a surgeon, "until the advancing age admits the efficacy and supremacy of Mind." 10

In deference also to the groundless fears of public opinion, "Mrs. Eddy advises that Christian Scientists do not at present treat contagious disease." 11

What is one to say concerning Mrs. Eddy's claim that Christian Science is an invariable specific for all human ills?

This first: A scientific test is needed, and Mrs. Eddy offers none in the averment that "the divine Principle of healing is proven in the personal experience of any sincere seeker of Truth." ${ }^{12}$ That is but to beg the question.

The growing disposition, voiced lately by the Committee on Publication, to admit some sort of diagnosis will not quite suffice. Diagnosis is to some extent determined by the personality of the physician and no diagnos- 
tician is infallible. While practically all physicians agree in diagnosing typhoid fever when the headache, weakness, loss of appetite, nosebleed, and increasing fever lead up to the characteristic rose spots and other abdominal symptoms, there are diseases Christian Science professes to cure which are extremely difficult to diagnose.

When, therefore, Judge Hanna remarks that Christian Science has cured hundreds of cases of cancer, one wants to know whether the diagnosis was in each case made by a capable doctor or by the patient, whether the growth was by microscopical examination demonstrated to be actual cancer or one of those non-malignant tumors which have been known to disappear without treatment, whether the cancer was a cancer of the stomach or a case of ulceration or chronic gastric catarrh in which, Dr. Osler says, "a positive diagnosis is impossible." 13

Seeking a scientific test which Christian Scientists would accept, Dr. J. B. Huber ${ }^{14}$ of New York some years ago addressed to Mrs. Stetson, then first reader in the foremost Christian Science church in New York city, a courteous letter containing such questions as the following: 
How do you define health?

How do you define disease?

Do you investigate symptoms?

Do you make diagnosis?

In what does your treatment consist?

Do you ever administer a material substance to a patient?

Do you ever isolate a patient sick of an infectious disease?

Do you ever treat structural disease, such as cancer or locomotor ataxia?

Do you consider you have cured such disease?

Can animals be cured by Christian Science methods?

Mrs. Stetson forwarded the questions to Mrs. Eddy. Mrs. Eddy passed them on to Judge Hanna; and this was his reply: "My conclusion is that it will be wholly impracticable-indeed I may say impossible-to answer these questions in such a manner as to make an entire paper fit for publication in a medical journal or in any other magazine or periodical."

And yet any well-trained doctor in the land could and would have given a precise and comprehensive answer.

An effort has been made by a psychologist ${ }^{15}$ to extract the information needed from Christian Scientists who have been healed of 
some disease. One evaded all the questions thus:

Whereas, before I was healed from chronic invalidism through the teachings of Christian science I used to think much on your topies, I wish never to think or refer to them again. . . . They are mental poison to me.

The leading questions, and, in another case, the answers were as follows:

What uas the nature of your malady?

It had none.

How long had you bcen afflicted with it?

Ever since the belief that disease was a substantial reality, instead of a negation.

How did you first discover that you were a victim of discase? Give fully your symptoms.

By a consciousness of limitation, i. e., finiteness.

How did the idca come to you that you could be healed?

The conviction ... that it was right to be well; and sickness was a wrong.

Was your cure instantaneous?

Yes.

How did you know that you were cured?

By the instant receding of disease, and the corresponding increasing of health and strength.

Did you know it at the time, or not until later? At the time: since Mind first perceiving the truth, its objective manifestation begins to appear.

Did you have to test it. before becoming convinced that a cure had actually taken place? 
No: it brought its own self-evident proof with it.

Not content with Judge Hanna's disappointing answer, Dr Huber undertook an investigation on his own account of Christian Science healing. He eliminated, first, the downright failures which there is some reason to believe are numerous. Then he made a careful examination of twenty so-called cures. Some were cured, he found, of diseases which they diagnosed themselves. Some under examination broke down and resorted to evasion. In no instance was the cure such as to cause surprise to any doctor who knows from personal experience that some get well who were not really ill, some because they cease to saturate their systems with unnecessary drugs, some because a new interest or a new affection sweeps them out of self, and a considerable percentage because they have in some way called up the power of natural recovery inherent in the body in many instances.

Mrs. Eddy never stays long on the defensive. She soon grows aggressive. She asserts that doctors have made no progress in the treatment of disease, that on the other hand they are to-day "flooding the world with diseases," and that the fewer the doctors, the less disease the world will suffer from. ${ }^{16}$ 
On many questions, history speaks with an uncertain voice, but not on this. History reports that positive and preventive medicine has in recent years decreased the death rate and increased the health and the longevity of the race beyond all credence. It is due in the main to medicine in the largest sense that Europe has no more of that "black death" which once swept millions out of life and depopulated cities, that the death rate of London has fallen from eighty to fifteen a thousand, and that of the British army in time of peace from seventeen to eight a thousand, and that in many sections fifteen years have been added to the average human life. ${ }^{17}$

It is due in the main to medicine that typhoid fever, which once took off 1228 in a nillion, now takes off only 137; that yellow fever, once a menace to our great seaports, is now under stern control; that diphtheria, once often fatal, is now rarely fatal when treated promptly; that Manila, for the first time in its history, has gone six months without a case of infectious disease; and that pneumonia, hydrophobia, and malaria are ceasing to occasion the alarm they used to bring.

It is due in the main to skilled medicine that in the recent Oriental war the Japanese 
army completely reversed the statistics of the Russo-'Turkish War with its eighty thousand deaths from disease and twenty thousand from wounds and of our Spanish-American War with its 3681 deaths from disease and 293 from bullets, and that it lost from disease only 11,992 , while 52,946 died of wounds received in battle. ${ }^{18}$

In surgery, which Mrs. Eddy expects soon will become merely mental, the facts make even more convincingly against her. Anæsthesia and asepsis have brought the mortality down in compound fractures from sixty per cent. to three, and in major amputations from fifty per cent. to two or three. ${ }^{19}$

Deformed bones were once considered hopeless. A Glasgow surgeon not long ago had but five failures out of one thousand eight hundred operations, and all the five were due to complications. Of hernia, which once was seldom operated on at all, an Italian surgeon reports 262 cases with but one death, a French surgeon 376 with two deaths, and an American surgeon 360 cases with one death.

With these facts, merely of course representative and not in any way exhaustive, to the credit of medicine and surgery one may well stand in pause before Mrs. Eddy's stout 
assertion that no progress has been made in medicine and surgery, that doctors are "flooding the world with diseases," that it is "not scientific to examine the body, in order to ascertain if we are in health," that the less known about hygiene the better, that we need "a body rendered pure by Mind, not by matter" [i. e. water], that massage "is another medical mistake," that food does not affect the real existence of man," that "dietetic theories" are "false reasoning," that "the daily ablutions of an infant are no more natural or necessary than would be the process of taking a fish out of water every day and covering it with dirt, in order to make it thrive more vigorously thereafter in its native element." ${ }^{20}$

Were we to act on Mrs. Eddy's strange assumptions, as we ought if they are warranted, all the beneficence of preventive medicine, and of the sanitary science which goes with it, would disappear. Filth and contagion would once more hold sway. Health boards would disappear. Problems of sewerage and water-supply would go unsolved. Slums would continue slums until the end. Healers and "medicine men" would be the order of the day to the disorder of the 
body. And in place of Florence Nightingale and Helen Gould and Anita Newcomb McGee, the angel of the modern battlefield would be Mary Baker G. Eddy from the serene security of Pleasant View radiating "absent treatment" to the firing line and to the hospital ward. ${ }^{21}$

Pressed to submit the Christian Science cures to such tests as have in every instance preceded the statistics offered in respect to medicine and surgery, Mrs. Eddy answers: "I submitted my metaphysical system of treating disease to the broadest practical tests. Since then this system has gradually gained ground, and has proved itself, whenever scientifically employed, to be the most effective curative agent in medical practice." ${ }^{22}$ Unfortunately, Mrs. Eddy has neglected to inform us when any test was made, on whom it was made, the circumstances of its making, the nature of the disease as determined by expert diagnosis, the time required to establish a perfect cure, and whether there was, as has often happened in her own experience, a relapse. ${ }^{21}$

If Christian Science has ever cured malignant cancer, we want to know from an expert diagnostician that the disease was cancer and 
not a tumor, ulcer, or catarrh. If Christian Science has ever cured a case of palsy, we have the right to know whether the case was one of hysterical paralysis or functional paraplegia, or on the other hand actual paralysis due to structural disease of the spinal cord or of some other part of the motor-nerve system. If Christian Science has cured true diabetes, which Dr. Osler ${ }^{23}$ says he has never seen cured, we have a right to know whether Fehling's test or Trommer's test or the fermentation test was used and whether it revealed diabetes or merely polyuria. If Christian Science has in any instance driven the malarial bacilli from their feast on the red corpuscles of the blood, we refuse to be convinced without a microscopic examination both before and after. And Mrs. Eddy's general statement that Christian Science healing has already " proved itself," is beside the mark.

Pressed further, Mrs. Eddy says that no test is required. "The divine Principle is proven in the personal experience of any sincere seeker of Truth," and "those only quarrel with her method who have not understood her meaning, or, discerning the truth, come not to the light lest their works should be reproved." ${ }^{24}$ And then she places all who 
in the interest of society would put Christian Science healing to a truly scientific test in an embarrassing position. She adds to the charge of insincerity the suggestion that all are morally unsound who want a scientific test,-an intimation which stills criticism at a cost which Christian Science can scarcely want to pay.

Mrs. Eddy has another reason in reserve for refusing to accept a scientific test for Christian Science healing. There is, according to her theory, no case to test. How can there be a body to get ill when there is no matter to constitute a body? Admit the existence of matter and we admit that morality (and therefore disease) has a foundation in fact. Deny the existence of matter, and we destroy the belief in these conditions and with it disappears the foundation of disease. Fevers are only "pictures depicted by mortal mind on the body." Inflammatory rheumatism comes not from exposure and infection but from fear. If you sprain a muscle or wound your flesh it is the mind that decides whether there shall be pain. "Colds, coughs, and contagion are engendered solely by mortal belief." "Tumor's, ulcers, tubercles, deformed spines are all dream shadows, dark images of mortal thought, which will flee before the 
light." And so all efforts to determine in the only way we can whether Christian Science is " the most effective curative agent in medical practice" lead to no result, and we pass on to Mrs. Eddy's next assumption. ${ }^{25}$

The Christian Science way of healing, says Mrs. Eddy, is the way that Jesus took.

What is the Christian Science way of healing? It is, the text-book indicates, the complete comprehension of "the Principle of Christian Science."

Nothing more is needed to effect a cure. "We never read that Jesus made a diagnosis of disease, in order to discover some means of healing it. He never asked if it were acute or chronic. He never recommended attention to laws of health, never gave drugs, never prayed to know if God were willing a man should live. He understood man to be immortal, whose Life is God,- - and not that man has two lives, one to be destroyed and the other to be made indestructible." ${ }^{26}$

Christian Science heals, therefore, by giving patients proper understanding. God is Principle. Man is God's idea, image, and reflection.

Your mirrored reflection is your own image, or likeness. If you lift a weight, your reflection does 
this also. If you speak, the lips of this likeness move in accord with yours. Now compare man, before the mirror, to his divine Principle, God. Call the mirror divine Science, and call man the reflection. Then note how true, according to Christian Science, is the reflection to its original. As in the mirror the reflection of yourself appears, so you, being spiritual, are the reflection of God. The substance, Life, Intelligence, Truth, and Love, which constitute Deity, are reflected by His creation; and we shall see this true likeness and reflection everywhere, when we subordinate the false testimony of the corporeal senses to the facts of Spirit." 27

The Christian Science healer learns to do this therapeutic trick in a very brief time. After a few lessons he goes forth to banish illness by denying that there are bodies to be ill, by erasing "the images of disease from mortal mind," by convincing mortal mind that it does not exist and that therefore its beliefs, which cause trouble, have no real existence. ${ }^{28}$

Always begin your treatment by allaying the fear of patients. . . . If you succeed in wholly removing the fear, your patient is healed. [Plead the case silently. By naming the disease audibly] you are liable to impress it upon the thought . . • Mentally insist that harmony is the everlasting fact, and sickness the temporal falsity. Realise the pressure of health, and the fact of harmonious 
functions and organs until the corporeal senses correspond with these normal conditions. ${ }^{29}$

If the patient seems to grow worse, do not be alarmed. "Calm the fear and confusion induced by chemicalisation, which is the alternative effect produced by Truth upon error; and sometimes explain the symptoms and their cause to the patient." 30

Mind will win at last. Death itself will one day be destroyed, for " death is but another phase of the dream that existence can be structural." "A demonstration of the facts of Soul, in Jesus' way, resolves the dark visions of sense into harmony and immortality." 31

"In Jesus' way." What was Jesus' way? One cannot be sure. About His methods Jesus was habitually silent. "Thy faith hath made thee whole" was as far as Jesus ever went in explanation of His cures. He never used the formulas of Mrs. Eddy. He never set forth any such metaphysical conception of the relationship of God and man as Mrs. Eddy entertains. He never even hinted that matter has no real existence and that in consequence men have no bodies to get ill.

Jesus always spoke and acted as though He had a body. He appeared at times to 
suffer some discomfort from His body. $\mathrm{He}$ seemed to be weary by the well of Jacob and upon the cross He sighed, "I thirst." $\mathrm{He}$ seemed to be hungry in the wilderness and on the shore of Galilee. He seemed to feel the piercing thorns. He seemed to find the cross a heavy load to bear along the via dolorosa. Once at least He cried out upon the cross as though in pain. Did He really feel the pain? Or did He know what Mrs. Eddy knows, that pain is non-existent? And was He therefore acting out a rôle $\mathrm{He}$ knew was false?

Mrs. Eddy is between the horns of a dilemma. How can she escape? If the pain of the crucifixion was as real as it appears to one who reads the poignant story to have been, then Jesus did not know, what Mrs. Eddy knows, that there is no pain in life and never has been pain. If Jesus felt no pain then $\mathrm{He}$ was the most consummate actor in all history, and since He took pains to create the impression that $\mathrm{He}$ suffered pain $\mathrm{He}$ added to the rôle of actor that of a deceiver of the world $\mathrm{He}$ came to save.

Mrs. Eddy perceives her dilemma and betakes herself again to her pet heresy. Once more she divides the personality of Jesus 


\section{Christian Science Healing}

Christ into two unequal parts: one of which, Jesus, suffered; the other, Christ, could not suffer, because under Mrs. Eddy's treatment $\mathrm{He}$ is resolved into a mere abstraction. She speaks for herself: "Jesus suffered, but the eternal Christ never suffered: for Christ is the idea of truth, and this idea comes to heal sickness and sin through Christian Science." ${ }^{2}$

Mrs. Eddy escapes from her dilemma, but she leaves Jesus in a worse plight than she was in. She degrades Him to a position lower than her own, lower than that of her followers. She knows there is no pain. She makes all healing dependent on the patient's full conviction that there is no pain. And yet she says of Jesus that when He "felt our infirmities He had not conquered all the beliefs of the flesh, or His sense of material life, nor had $\mathrm{He}$ risen to His final demonstration of spiritual power." 33

Mrs. Eddy understands, her followers understand, the truth about pain; but Jesus did not understand. He was not so wise as she. He was a fledgling, not a full-grown Christian Scientist. Mrs. Eddy saves herself from the cul de sac into which her novel thinking leads her, but she leads Jesus into a worse one, and, extracting the Christ principle from 
Him in order to have a Christ to come again one day in Christian Science, she there leaves Jesus evermore, less than man according to the Christian Science pattern, far less than the woman who interprets Him.

The Christian Science way as Mrs. Eddy points it out can scarcely be the way which Jesus took to heal the sick.

Granted in the interest of discussion that Christian Science healing is the mental healing of Jesus and the early Church, has there been no healing like it in the ages since till Mrs. Eddy's day?

Once more, appeal is possible to facts. ${ }^{34}$ All along the Christian centuries, if history is credible, witnesses have testified in all devoutness and sincerity to Christian healing. Athanasius, Ambrose, Chrysostom, and Augustine cite instances in the fourth century. In the fifth, we have the testimony of Hilary and Jerome. Gregory the Great, Augustine of Canterbury, and Cyril testify for the sixth century. Cuthbert and Bede had cures accredited to them. Eginhard, an intimate of Charlemagne, set down in a book his observations of extraordinary cases.

The so-called "false miracles" of the dark ages, wrought through faith in bones and 
relics, were works of mental healing if they were anything at all. Catharine of Siena, in 1373, called a priest back from the gates of death, and Luther thought he kept two men from the grave by prayer. Bishop Parkhurst and D'Aubigné bear witness to the marvels of the sixteenth century. Charles II. touched one hundred thousand persons suffering from the king's evil (scrofula), and Queen Anne laid her healing hand on young Samuel Johnson. Moravians, Waldenses, Puritans, Presbyterians, Huguenots, Baptists, Methodists, all in one way or another bridged the gulf between the Reformation and the nineteenth century by their healing works.

There was not a decade in the nineteenth century but had some testimony to give concerning mental healing, done of tenest in Jesus' name. The story of Sir Humphry Davy and his palsy patient, who mistook the clinical thermometer placed beneath his tongue for a new remedy and rapidly got well, is a staple among mental healing stories. Parson Chiniquy was cured of typhoid fever in 1837 by a vision of St. Anne and again in 1858 by the will to get well. Parson Blumhardt, with his faith healing on the continent, was matching Quimby and his work at the same period in 
this country. And since the little shepherdess had her vision of the Virgin fifty years ago such miracles of Christian healing have been worked atLourdes that Charcot in his later life every year sent patients whom he could not cure in his hospital to the little town in the Pyrenees and seldom sent in vain. Mrs. Eddy, Dowie, Simpson, Schlatter, Schrader, and Bradley Newell have all been names to conjure with in recent years. After two years of patient study, on such terms as were obtainable, of some sixteen hundred cures attributed to them, Professor Goddard, trained psychologist, reports that the diseases, according to the patient's word, covered almost the whole field of pathology, with nervous troubles in the lead; 33 per cent. of the patients claimed to have been instantaneously healed, 50 per cent. gradually, and 17 per cent. incompletely.

Professor Goddard's final judgment concerning all such mental healers is:

They all cure disease and they all have failures. They all cure the same kind of diseases and the same diseases are incurable for them all. In those classes of disease where the cures are wrought, there are the same percentages of cures by all the methods. Stripped of a few character- 
istic phrases the reports from all the different forms are the same. A testimonial to a patent medicine, for example, reads precisely like one of Dowie's reports of a divine healing cure. Again there are many records of people going from one school to another and in this no one practice seems to show any advantage. Some fail after trying all. Some fail to get cured by divine healing, but get restored by Christian Science, and vice versa. Others fail with Christian Science and are successful in hypnotism, and vice versa. ${ }^{35}$

But there is, these days, drugless healing of which it is possible to speak with more precision. It is the mental healing to the undisputed credit of the nervous specialists of standing in the medical profession. The diagnosis in each instance is as nearly accurate as diagnosis can be. The methods have no mystery enshrouding them. The results are as beneficial as perhaps can be secured. And no cure is announced that will not stand the test to which Christian Science steadily refuses to submit its cures.

Van Rhenterghem reports that of 162 cases of rheumatism, hysteria, neuralgia, epilepsy, indigestion, and deafness which he treated without medicine 91 were cured, 46 improved, and 25 did not improve. ${ }^{36}$ Parkyn, who treats only nervous troubles, reports a 
cure in every case of nervous prostration. Bernheim's De la Suggestion à la Therapeutics is a continuous chronicle of the drugless cure of cerebral hemorrhage, paresis of traumatic origin, violent hysteria, nervous aphonia, general chorea, chronic gastritis, epigastric pain, rheumatism, neuralgia, and insomnia. Dubois's book, recently translated, on The Psychic Treatment of Nervous Disorders, makes clear-for Dr. Dubois has had twenty years of successful practice at Bernethat mental healing is as surely a specific for neurasthenia, hysteria, hypochondria, melancholia, and the other well-known ills which lie between normal health and insanity, as quinine is for malaria.

Including, as we should, hypnotism in the catalogue of mental healing, we find results that will stand any test. Of 414 cases, which included 29 organic diseases, 39 severe neuroses, 60 mental diseases, 233 neuropathic disorders, and 44 functional derangements, 28 per cent. were permanently cured, 27 per cent. visibly improved, 26 per cent. received some benefit, 20 per cent. were not affected one way or the other, and in one per cent. the result was unknown.

As to surgery, which Mrs. Eddy would 
for the present leave to the surgeon, even major operations have been performed with hypnotism in the place of etherisation. As long ago as 1846 Esdaile was by means of hypnotism amputating arms and legs without causing pain; and more than a dozen European specialists have repeatedly conducted women through the perils of childbirth without consciousness, recollection, or any painful after consequences. ${ }^{37}$

But the catalogue of drugless healing is not to-day complete without a word concerning the Emmanuel Movement in progress this year past in Boston, almost within the shadow of the Christian Science church. The movement is based upon sound principles. It recognises the limitations of suggestion. It deals only with functional and nervous disorders. Diagnosis is invariably made by an expert physician. Suggestion is reenforced at every point by faith in the fundamentals of historic Christianity. It is, in fact, a serious "attempt to weld into friendly alliance the most advanced medico-psychological knowledge of our time and a primitive, New Testament Christianity, as scholarship has disclosed it."

Though results have not as yet been systematically reported, it seems likely to those 
who have made a careful study of the movement that this year past hundreds of cases of neurasthenia, hysteria, hy pochondria, insomnia, certain forms of paralysis, various functional disturbances, suicidal tendencies, and immoral habits have been permanently cured. It was with this experiment in mind that Dr. Llewellys F. Barker, who succeeded Dr. Osler at the Johns Hopkins University, recently remarked: "Men and women, generally, as well as medicine and science, are coming to a realisation of the high part played by the mind in matters affecting the body. But this knowledge can only exert its full and true value through a proper combination of the best revealed science and religion." 38

What is the principle-for there must be one-which underlies all mental healing, whether that of Christian Science, the New 'Thought, the nervous specialist, the Emmanuel Movement, or the family doctor who is constantly employing it without pretension or profession?

Three hundred years before Mrs. Eddy announced that "whatever is cherished in mortal mind as the physical condition is imaged forth on the body," Spenser wrote:

"For of the soule, the bodie forme doth take, For soule is forme, and doth the bodie make." 
But for a scientific statement we turn again to the psychologist. Professor Goddard says: "The idea of health tends to produce health in proportion to the strength of the idea to be met, or inversely as the opposition to be met." ${ }^{39}$

Now the principle emerges into view. It is the idea of good health that tends to bring good health. It is the suggestion of the idea that constitutes the common principle we seek. Some mental healers resort to one device in suggesting the idea; others to another. Whatever gives the greatest impetus to the suggestion is the most effective. Mrs. Eddy's metaphysics has in itself, probably, no more therapeutic value than the tom-tom of the "medicine man." A false belief, as Paracelsus and Pomponazzi remarked centuries ago, may be as efficacious for therapeutic purposes as a true one. Christian Science has won a place in mental therapeutics not because it has discovered any principle in place of the common principle of suggestion, but because its founder, gifted as she is with unusual hypnotic power, has made its strange metaphysics a motive power to suggestion.

But suggestion has its limitations. If every idea does tend to "generate its actuality," the tendency is sometimes checked. 
There are certain anatomical changes that frustrate the mind's desire to replace "as readily as the lobster's claw" the limb lost in the railway accident. There are certain hard and stubborn facts which would seem to stay the mental healing of the wilted rubber plant and the sick horse.

These limitations are not always easy to describe. But they are usually recognisable. Allowance must invariably be made for them. The way of Christian Science is strewn with broken hearts and maimed bodies, ruined health and lives sacrificed, because under the hypnotic spell of Mrs. Eddy her subjects have refused, except under compulsion of public indignation or of the law, to make such allowance. Christian Scientists may take comfort from the words of Professor William James, pragmatist as he is, that the state is not called upon to pronounce between rival schools of medicine, but the intelligent public will not give to Christian Science the free hand it desires and means to have, until definite assurance has been given that Christian Scientists do recognise the limitations of the principle of suggestion and are content to do their work within those limitations.

It is in the hypnotic treatment of disease 
that suggestion becomes an actual specific. Hypnotism is nothing but suggestion so persistent and profound as to induce an artificial sleep in which all mental opposition is silenced and all possible untoward influences are excluded. 'There are dangers in its use as there are dangers in the use of all good things. It can conceivably be put, and sometimes is put, to questionable purposes; so, too, is arsenic. But for Mrs. Eddy to fulminate against hypnotism on the score that it is "error," " mental malpractice," " animal magnetism," and to threaten excommunication to the follower who, for instance, may want to read his Bramwell or his Moll or the new edition of Lloyd Tuckey's monumental work, is to add to the tale of evidence steadily accumulating that Mrs. Eddy knows no science save the pseudo-science she herself sets up, and is to disqualify her and her interpreters to speak on any mental therapeutic question.

The conclusion, then, to which one comes at last is this: that, like all other systems of mental healing, Christian Science rests upon the well-established principle of suggestion. The philosophy of Christian Science is purely adventitious, as is proved by the career of Quimby, who, according to his pupil, Dr. 
Evans, obtained large results merely by suggestion. ${ }^{40}$ Its exact therapeutic value, in spite of the amazing testimonials it presents, cannot be determined till Christian Science is ready to submit its cures to truly scientific tests. That Christian Science does call for state regulation is evident to those who believe the state has duties to her adult ignorant as well as to her little children.

One would be as generous as possible to any faith which can re-enforce suggestion. But there is a duty to the mind as well as to the body, and if one must choose between the good health of mind which always comes from cleaving to the truth and the good health of body which may come in certain cases with the acceptance of a false philosophy, the normal and the wholesome will prefer to

"Look straight out-

see things-not try to evade them.

Facts shall be facts for me, and the truth the truth forever." 41 


\title{
CHAPTER VIII
}

\author{
MARRIAGE AND THE FAMILY
}

The Gravest Defect-Christian Science Ascetic-Mrs. Eddy's Testimony Prompted by her Personal Experience-Denies the Sacramental Use of MatterMisinterprets Jesus' Words-Teaches Possibility of Race Perpetuation without Marriage-Some Explanations which do not Explain-Simultaneous Contradictions-The Testimony of the Manual and the Lesson Quarterly-The Obvious Tendency-Public Opinion Making Ready for a Final Judgment-The Alternative-Duty of the Hour.

\section{T}

HE gravest defect of the Christian Science system yet remains to be considered. Christian Science is in essence ascetic. I use the word advisedly. I have read and re-read in seven editions of Science and Health, ranging from 1875 to 1906, Mrs. Eddy's chapter on marriage. I find in it many high ideals, many practical suggestions. It is gratifying to hear any woman, and especially a woman 
whose matrimonial experiences have been so varied and unsatisfying that she writes, marriage " is often convenient, sometimes pleasant, and occasionally a love affair," ${ }^{1}$ lift her voice against divorce and counsel married people to stay married until death. I know that some families have been blessed by the conversion of their members to Christian Science. I know that a new conception of the dignity and spiritual value of self-control has been lodged in many a mind. I know that many a husband has been reclaimed from dissipation, many a wife from frivolity, by the call of the spiritual which in spite of all its error does echo from Science and Health.

And yet, allowing liberally for all that, Christian Science is in essence ascetic. Mrs. Eddy says it is, and she should know. "Is marriage nearer right than celibacy?" she inquires, and then replies, "Human knowledge inculcates that it is, while Science indicates that it is not." 2 By its insistence on the unreality of matter Christian Science logically disavows the sacramental character of marriage, makes it but a temporary stage in the development of the race, and loosens the ties affection or kinship forms.

I could give instances-for I have made 


\section{Marriage and the Family}

inquiries far and wide-in which families that have for long years known only happiness and concord have suddenly become the prey of discord and division, ${ }^{3}$ in which the love of husbands for wives and fathers for children has dissolved into an unfortunate aloofness, in which wives have ceased, except in name, to live as wives and mothers have come to think of children as millstones round their necks, in which daughters have ceased to be daughters except before the world, and sisters have separated for all time from sisters who declined to go with them into Christian Science, in which lovers have broken their engagement and friends have given up their life-long friendship for no reason save a difference in the point of view concerning what is nothing after all except a problem in pure metaphysics.

Some men may for good reasons remain celibate as Jesus did, and there is on them no reflection. Some women may be virgins till the last, and that, too, is apparently the will of God for some. But the norm is never celibate or virginal. The norm is marriage, because only in the perfect union of a man and woman is there at the same time promise to the individual of completeness, and to the 
race perpetuation in circumstances that ensure the proper training of the young.

You will seek in vain in the pages of Science and Health for any evidence that this fact, perhaps the most important fact in sociology, has any place in Mrs. Eddy's mind. Holding that there is no such thing as matter, she sees no sacramental use for matter. Believing that "matter is not the medium through which the Spirit acts," 4 it is impossible for her to take the view of marriage which those hold who have the sacramental view of matter. No intellect can be big enough to contain two views that flatly contradict each other.

With this in mind, it is easy to understand Mrs. Eddy's treatment of marriage and the family. She goes back once again to Jesus. She explains the immaculate conception by the identification of Christian Science with the Holy Ghost: "The Science of being overshadowed the sense of the Virgin mother, with a full recognition that Spirit is the basis of being." 5 She calls "His birth what every one's should be." " She says the time is coming of which Jesus spoke when $\mathrm{He}$ declared that there shall be no more marrying nor giving in marriage. She insists that "matrimony must lose its present slippery 


\section{Marriage and the Family}

footing and find permanence in a more spiritual adherence." ' Though " to abolish marriage at this period, and maintain morality and generation, would put ingenuity to ludicrous shifts," she still insists that "this is possible." s She longs for a day when marriage shall have passed away, and adds: "Proportionately as human generation ceases, the unbroken links of eternal harmonious being will be spiritually discerned; and man not of the earth earthly but coexistent with God will appear." 9

Now what does all this mean? What can it mean but this: that as the Holy Ghost, who Mrs. Eddy says is really Christian Science, once overshadowed a woman and the Virgin Birth was the result, so will it be again when women submit themselves to Christian Science as the mother of the Master did.

Mrs. Eddy makes appeal to Scriptures. She regards marriage, her interpreter remarks, " in the exact sense in which it is taught in the Scriptures." He explains that "Christian Science, like Christianity, points to the higher spiritual life above and beyond the pale of marriage as Jesus did in His declaration 'but they which shall be accounted worthy to obtain that world, and the resurrection from the dead, 
neither marry, nor are given in marriage.'"

Nothing could be clearer than these words. The trouble is that they furnish another glaring instance of the proof-text habit which has often brought the Christian Scientists to grief. The passage quoted from St. Luke appears in its essentials also in St. Matthew and St. Mark, and taken with the context in each instance evidently means that marriage, birth, and death belong together in this world, and will therefore have no place in the world to come. It means nothing more than that and cannot be given a Christian Science colouring. Jesus often spoke about the resurrection life as though it is to have no sacramental interests since the body then will be no longer physical but spiritual. ${ }^{10}$

St. Paul lights up the situation with his conception, for which many words of Jesus furnish apparent justification, of the immediate second coming of our Lord. $\mathrm{He}$ writes to the Thessalonians:

For the Lord himself shall descend from Heaven with a shout, with the voice of the Archangel, and with the trump of God: and the dead in Christ shall rise first. Then we which are alive and remain shall be caught up together with them in the clouds, to meet the Lord in the air: and so shall we ever be with the Lord. ${ }^{11}$ 
But Mrs. Eddy teaches, as we have long since learned, that the body is already as spiritual as it will ever be if we will but believe it is, and that Christ has already come again in Christian Science. The time is therefore evidently ripe for all who would live up to the central principle of Christian Science, to proclaim with the mad Hamlet: "We will have no more marriages: those that are married already ... shall live; the rest shall keep as they are."

In the face of all these facts Mrs. Eddy's spokesman still insists that she is conventional in her views of marriage. He says she has never advocated any other method for the perpetuation of the species and singles out in proof a doubtful word from her Retrospection and Introspection. ${ }^{12}$

The appeal is made to Cæsar. 'To Cæsar let us go.

In the first edition of Science and Health, published in 1875, Mrs. Eddy puts herself on record thus:

The material world, at a future time will become a spectacle of disorder and dismay on one hand, and of Science on the other. There will be convulsions of mind and consequently of matter, spasms, earthquakes, famine, and pestilence. Sickness will 
become acute and death more sudden: but to those who understand this hour, as explained in the science of being, length of days will increase, and harmony and immortality be near, even at the door. Knowledge will then diminish and lose estimate in the sight of man: and spirit instead of matter be made the basis of generation. ${ }^{13}$

In 1881 we find her writing: "The time cometh when there will be no marrying or giving in marriage. . . Soul will ultimately claim its own, and the voice of personal sense be hushed." 14 In 1888 she states that "marriage is the only legal and moral provision for generation among the higher species"; but then she neutralises her words by the hint that marriage will no longer be when people learn that "generation rests on no sexual basis." 15 Ten years later she remarks that reproduction is due to belief, and in illustration later adds: "The propagation of their species by butterfly, bee, and moth, without the customary presence of male companions, is a discovery corroborative of Science of Mind." 16

Troubled by the storm of criticism, in the latest editions of Science and Health, Mrs. Eddy sets herself at the correction of the reader's true impression of her views. She 
vows in 1906 that the only person she has ever known who believed in agamogenesis "was suffering from incipient insanity," 17 and hints that she is not that person. But it is difficult to take Mrs. Eddy seriously when in the next paragraph appears the sentence that "proportionately as human generation ceases, the unbroken links of eternal harmonious being will be spiritually discerned "18; when later in the book there reappears the analogy above of the butterfly and bee and moth; and when she states outright that "to no longer marry or be given in marriage" does not mean race suicide. ${ }^{19}$

But if we have failed to grasp the meaning of Mrs. Eddy's words, if we are to be guided solely by her latest, not her earlier utterances, and to assume that the correction of some passages implies the correction of all, if Mrs. Eddy does believe with heart and soul in the perpetuation of the species sacramentally through marriage in the years to come as in these ages past, why does not the great organ in the Mother Church at Boston more frequently peal out the wedding march? Why is no Christian Scientist specially commissioned to solemnise a marriage? Why is the Church Manual, which is so explicit in its directions 
on all other themes, silent as to marriage, except for this one ominous note: "If a Christian Scientist is to be married, the ceremony shall be performed by a clergyman [of some other fold] who is legally authorised "? ${ }^{20}$ And why has not the Mother Church in Boston, with its seating capacity of five thousand and its resident membership doubtless larger, made provisions for a larger Sunday-school than one of two hundred and fifty members? ${ }^{21}$

Is it conceivable that informed Christian Scientists are ignorant of these facts which an outside student has so easily unearthed? Certainly no Christian Scientist can be uninformed who was at a Christian Science service anywhere on Sunday, May 5, 1907. For according to the directions of the Christian Science Lesson Quarterly, which has the sanction of the sage of Pleasant View, every Second Reader in the world read to the Christian Science thousands everywhere that day these words from the Bible: "After this I looked and, behold, a door was opened in heaven: and the first voice which I heard was as it were of a trumpet talking with me; which said Come up hither, and I will shew thee things which must be hereafter." And 
then the First Reader antiphoned in voice sonorous and mellifluous: "Proportionately as human generation ceases, the unbroken links of eternal harmonious being will be spiritually discerned."

The American public, which insists upon publicity on all dark spots in public life today, is beginning to suspect that Mrs. Eddy, who has had three husbands and one child, has one view for her followers and another for the world, that she is secretly encouraging the dangerous theory that marriage and celibacy are now possible, or will some day be, in the same home without race suicide ${ }^{22}$ and disarowing it through her official representatives when questioned by the now suspicious public. If the suspicion is unwarranted, it can be allayed not by overlaying the objectionable passages with explanations which do not enlighten, but by cutting them out root and branch.

There is no reason for alarm, 't is said. It may be centuries before "the world reaches the point of perfect spirituality where there will be no flesh to propagate."

The duty is, however, Mrs. Eddy constantly insists, to make ready for the day. Give up your sacramental view of life. Put off the 
obligations it involves. There is a higher estate in marriage than parenthood, and any woman who can win her husband's consent may decline motherhood to "win a higher" married state. ${ }^{23}$ "He that loveth father or mother more than me is not worthy of me," ${ }^{24}$ Mrs. Eddy announces even to prospective servants. "Jesus," she says, " acknowledged no ties of the flesh." ${ }^{25}$ Jesus "teaches mortals to lay down their fleshliness in order to gain spirituality," she remarks in curious confusion of the flesh with the ties of the flesh. The duty is to make the least and not the most of all relationships. ${ }^{26}$ God "is man's only real relative on earth and in heaven." ${ }^{27}$ "Would existence be to you a blank without personal friends?" "This vacuum must be filled with Principle instead of person." ${ }^{28}$ Do you long for

". . the touch of a vanished hand, And the sound of a voice that is still"?

"When our friends pass from our sight and we lament, that lamentation is needless and causeless." ${ }^{29}$

"Pain and grief are shards of the poignant dream That matter is supreme." 30

But why multiply our instances? Now we 
see whither Christian Science tends. It tends ultimately, when a generation of pure Christian Scientists shall have succeeded this, more Christian after all than Christian Scientist, toward the disintegration of the family.

If there is one cause for which all who love their kind must stand together in these days it is the family. Only as we first make the most of the family can we next make anything of society at large. Only as we give ourselves devotedly to the relationships of home, loving ardently, missing unspeakably when death intervenes, in every way loyal and obedient to the bonds of pure affection, shall we have anything to give to man or God outside the family. All of Mrs. Eddy's talk about the love of God apart from love to those who have first right to our love is beside the mark. One would think she has never heard St. John's penetrating question: " $\mathrm{He}$ that loveth not his brother whom he hath seen, how can he love God whom he hath not seen?"

There is no such thing as abstract love. Love exists only in relationships. That is the reason why God has always been, before the world began, a social God, a Trinitarian God. It is only by becoming so ineffably dear to one another that the pain of one is another's 
pain, the death of one another's heartbreak, that society can hold together. Loosen the family ties by transferring the affections to a mere abstraction by the name of Principle, create the suspicion that God has claims on any one which take precedence of the duties of the family, twist the words of Jesus to purposes unwarranted by exegesis or steal them from their context or make them contradict His life-long policy and His world-wide influence in the upbuilding of the family, and civilisation will crumble, the family will fall to pieces, and any saving remnant there may chance to be will have to face the sore temptation of the Gnostics who began by denying the existence of the flesh and ended by indulging it. ${ }^{31}$

Mrs. Eddy may be right and we wrong. But it will require more than Mrs. Eddy's word to convince us,

\section{"who live beneath}

The shadow of the steeple; The parson and the parson's wife,

And mostly married people," 32

that all the tears and blood, the tragedy and travail of countless years to make love rule in the sacramental relationships of family and 
church and state, are mere illusions to be flung aside whenever Mrs. Eddy thinks we know enough to do without them.

Furthermore, as the perilous and the pernicious in the metaphysics of Christian Science grow more evident, public opinion, which always has the final word, will grow more insistent that Christian Scientists divorce their philosophy from their healing, recognise the limitations of suggestion, submit their system to an honest scientific test, and give it a more modest place among the various forms of mental healing which are perhaps doing as good work as Christian Science without detaching people from their normal church relations or fooling with the fundamentals of experience.

If Christian Science, in spite of every warning, persists along its present course, public opinion will one day place it legally in the category where it logically belongs, with all those subtler types of anarchy which disappear when men see them as they are.

There are three stages through which many of us pass who study Christian Science with the desire to find out what it really is.

1. The stage in which we are somewhat 
amused at its conspicuous absurdities, at which Christian Scientists themselves have been known to smile, and yet speak not against it because we have seen instances in which sick bodies and sick souls have seemed to improve under its influence.

2. The stage in which we are for a time bewildered by the other-worldliness and serenity of many a Christian Science character and wonder if after all there may not be much in Christian Science.

3. The stage in which after hard reading and honest thinking we see the structural weakness of its philosophy, its frequent misrepresentations of the teachings of our Lord, its denial of the limitations of suggestion in the interest of a grotesque theory, and its insidious attack upon the family at the very source even while it inculcates many family virtues.

And when we reach the third stage there is one thing and one only for those to do who feel some responsibility to " the God of things as they are." That is, to state the entire truth concerning this fatuous folly which seems to have a weird affinity for crude intellects and undisciplined emotions.

Christian Science will not crush historic 
Christianity. Truth needs no caretakers. Truth needs only witnesses. But there are in every church good people, simple, honest and devout, who have had little or no training in philosophy or science. It is they whom Christian Science of tenest allures from their allegiance. It is with them in mind that every thoughtful reader of this book who loves his fellow man will lose no opportunity to explain exactly as it is the theory and practice of Christian Science until in the white light of publicity the error and the evil in it shrivel up and disappear, and it takes its place among the far too many sects which justify themselves by the pragmatic quickening they give to souls untouched by other agencies.

If this brings unhappiness to some who now find comfort in the Christian Science faith, there is but one word to be said, that duty to truth comes before the privilege of happiness. No comfort, no serenity, no peace can last which does not rest on truth. As a wise Englishman has said:

Those who flinch from inquiry because they dread the possible conclusion; who turn aside from the path as soon as they catch a glimpse of an unwelcome goal; who hold their dearest hopes only on the tenure of a closed eye and a repudiating mind, 
will, sooner or later, have to encounter that inevitable hour when doubt will not be silenced and inquiry can no longer be put by; when the spectres of old misgivings, which have been rudely repulsed, and of questionings, which have been sent empty away, will return to "haunt, to startle, to waylay," and will then find their faith crumbling away at the moment of greatest need. ${ }^{33}$ 


\section{NOTES}

The following abbreviations are used: S. \& H. for Science and Health; M. W. for Miscellaneous Writings; R. \& I. for Retrospection and Introspection; P. \& P. for Pulpit and Press; C. S. v. P. for Christian Science versus Pantheism; and C. S. invariably for Christian Science.

The writer has made use of several editions of S. \& H. When no date is given the edition of 1906 should be assumed. The edition of 1898 is often cited because it contains an excellent index omitted from recent editions in the interest-it would seem-of the new Concordance of which the selling price is five dollars.

References to magazines, weekly journals, and daily papers are for the year 1907 unless another year is given. Where more than one book by the same author is mentioned the specific reference is always to the first book listed in the Bibliography, p. ix. under the author's name.

To the Bibliography should be added James's Pragmatism and The Christ that is to be, which has appeared since the Bibliography passed into proof.

\section{CHAPTER I}

1. R. \& I., 20.

2. S. \& H., VII.

3. S. \& H., 126.

4. S. \& H., 107.

5. McClure's, March, 507.

6. Manual, 3.

7. Letters dated December 5 and 18, 1890, written by Mrs. Eddy.

8. C. S. Bible Quarterly Lessons, April-June; Explanatory Note. The italics appear in the Quarterly. 
9. R. \& I., 89 .

10. S. \& H., 202.

11. R. \& I., 88 .

12. S. \& H., 474.

13. S. \& H., 131-142. On his visit to Mrs. Eddy, August 12th, Dr. Allan McLane Hamilton found that Mrs. Eddy even in her earlier life had the habit of " criticising the older ministers."-C. S. Sentinel, Aug. 24.

14. S. \& H., 142. As the author reads these notes in proof a new edition of S. \& H. appears in which Mrs. Eddy makes the passage more severe by substituting the word "worship" for "policy."

15. Manual, 57.

16. M. W., 106.

17. S. \& H., 201.

18. McClure's, May, 103. In S. \& H., 324, Mrs. Eddy describes the new convert to $\mathrm{C}$. S. as full of "gladness to leave the dark landmarks and joy to see them disappear."

19. The Christian Science Publication Committee (Human Life, January, 1907, p. 5) states that "the Christian Science Church does not proselyte." Yet Mrs. Eddy (Manual, 79) appears by implication to encourage proselyting, except among Roman Catholics. It is a self-evident fact that the C. S. Church is made up largely of "come-outers." Dr. F. J. Fluno, Christian Science Lecturer, says every convert "brings ten." Every clergyman who has lost members of his flock to C. S. understands the pervasiveness of C. S. proselyting. While the policy is not to seem to make it easy to join the C. S. Church, the way is always indicated by the constant pressure, especially in the care of those under C. S. treatment for some ills, to exclude all intellectual interests except those for which S. \& H. stands, to confine the fellowship to those of C. S. sympathies, and to give more thought and time and affection to the development of C. S. friendships than affinity or the fitness of things would sometimes indicate. While these are the facts in evidence, the author is glad to testify that the motive seems to be identical with that of the early Christians, - to drive out the old in order to 
substitute a new faith believed to be the only true faith.

Mrs. Eddy hints (S. \& H., 328) that the Bible is erroneously interpreted by Christian missionaries in India because hundreds still die there every year from snake bites. She is apparently ignorant of the real nature of the work missionaries are doing everywhere. "They are," says the New York Evening Post, "physicians as well as priests. They build hospitals and administer them. They establish printing presses and direct them. They are linguists who translate a whole religious literature into the imperfect dialect of primitive tribes. They are advisers at the courts of Eastern princes, and instructors at colleges planted in regions of dense ignorance. They are usually in advance of traders, and find themselves at length opposing the vices of civilisation on the one hand and those of barbarism on the other." When Christian Science turns its energies away from winning Christians to the winning of the heathen it will then be time enough to criticise the missionary efforts of the Christian Church.

20. Cushman, 16; Newton, 2; Mark Twain, 286; Broadway Magazine, May, 151; Rev. Lewis R. Bates, D.D., quoted in C. S. Sentinel, Aug. 10.

21. Snyder, 2.

22. Case.

23. Isaiah $1: 13,14$; Micah $6: 8$.

24. Arena, January, 59.

\section{CHAPTER II}

1. S. \& H., 456.

2. C. S. B. Q. Lessons, Exp. Note. Rev. Irving C. Tomlinson, official representative of Mrs. Eddy, thus comments: "The Bible and the C. S. text-book are our only preachers. As the discourses are made up wholly of passages from the Bible and the C. S. text-book, they contain nothing of human opinion; they are devoid of man-made theories. They voice the eternal fact concerning the everlasting Truth. They set forth the realities of being; they inform, instruct, and enlighten 
concerning the verities of God and man."-Reprint from the C. S. Sentinel.

3. R. \& I., 55.

4. Mark Twain, 142 .

5. Manual, 31.

6. New York Sun, Feb. 25, 1903.

7. Mark Twain, 257.

8. Northampton (Mass.) Herald, Feb. 16 and 18.

9. Compare successive editions of $\mathrm{S}$. \& H.

10. C. S. B. Q. Lessons, Ibid.

11. The author has made the estimate of Mrs. Eddy's wealth from the affidavits, not altogether clear, filed in Concord, N. H., May 17 and 18, and published in the C. S. Sentinel of May 25. In the "Masters" interview, Aug. 14, with Mrs. Eddy as reported in the Boston Herald, Aug. 15, Mrs. Eddy admitted the transfer of property amounting to $\$ 913,000$ to trustees. This apparently does not include her real estate in Concord now assessed at $\$ 55,000$ according to counsel for "next friends" in the recent lawsuit, and other investments which so far as the reader can determine are indicated in the C. S. Sentinel of May 25 and apparently bring her estate up to or beyond the million dollar mark. The amount must be a surprise to Mrs. Eddy's followers as well as others; for in his C. S. History, published a few years ago, Judge Hanna after stating that Mrs. Eddy's charities from 1896 to 1899 averaged $\$ 88,987$ a year, adds that but for her economical habit of living Mrs. Eddy would be a millionaire. Her fortune at her death, the C. S. Sentinel of Aug. 24 informs us, is to go to her church.

It has been stated that there is no compulsion on any one to buy S. \& H., and that those outside, since they have access to copies in the public libraries, have no right to criticise the author of the book for selling it at a price apparently prohibitive to some. The twofold reply to this is evident: (1) The ethical sense of the modern world has advanced beyond the point the C. S. Sentinel (quoting from the Concord Daily Patriot), Aug. 24, p. 967 , makes that " a fortune" is or can be "the logical result of the teachings" of a great religious leader. It is 
now too late in the development of the country's ethical instinct to make acquisitiveness a Christian virtue. Christianity will not to-day consent to put a premium on the money-getting which Mrs. Eddy's whole career has illustrated in general, and her management of S. \& H. has emphasised in particular. (2) The ethical sense of the modern world is now engaged in bringing to justice certain large corporations which are extracting enormous profits from the pockets of the poor for the necessities of life. Mrs. Eddy's constant claim that S. \& H. is necessary to man's well-being, to his actual existence if he happens to fall ill, makes the book to those who follow in her train as truly a necessity as food and oil are to the world at large. To hold her book at a price relatively as high as that the corporations set upon their wares is logically to invite the same condemnation they are now receiving. To solve the problem by giving copies gratuitously to those obliged to plead their poverty is spiritual pauperisation. To send them to C. S. reading-rooms or public libraries is "soup-house" evangelisation. The modern conscience is not content with the suggestion.

For years Mrs. Eddy steadily encouraged her followers through the pages of the Journal of Christian Science in giving her presents. She regularly published in its columns the list of presents sent her, including once "a 21-pound turkey," again an "eider-down pillow," once again a "linen handkerchief." A partial list will be found in McClure's, October, 689, 690; also a letter, of which the writer has seen the original, written by Mrs. Eddy in 1890 to her publisher in protest against his suggestion that she omit her list of Christmas gifts from the Journal. The following is her ingenious argument: "Students are constantly telling me how they felt the mental impression this year to make me no presents, and when they overcame it were strengthened and blessed. For this reason, viz., to discourage mental malpractice and to encourage those who beat it-I want that notice published." To the inference that Mrs. Eddy was soliciting presents there is but the alternative that, according to her theory, she was under the dominion of the obsession 
of malicious animal magnetism and was therefore not responsible for her conduct. The italics above are Mrs. Eddy's.

12. Mark Twain, 254.

13. S. \& H. (1898), 443; Cosmopolitan, March, 541; July, 331.

14. Wood, 146-152; Patterson, 9-22.

15. Wright, 17, 28, and McClure's, October. John Henry Wiggin was one of the cleverest and most cultivated men ever in any capacity associated with Mrs. Eddy. From 1885 to 1890 he was her literary adviser. $\mathrm{He}$ assisted in the editing of the Journal, and rewrote $\mathrm{S}$. $\& \mathrm{H}$. so that in the edition of 1886 it became practically a new book in form and phrase. One chapter called "Wayside Hints," was in thought as well as word the work of Mr. Wiggin. Mrs. Eddy first used it Jan. 24, 1886, as a sermon without accrediting it to Mr. Wiggin, and after the service with eyes twinkling inquired of him in a stage whisper "How did it go?" Then she inserted it bodily in S. \& H. adding in one paragraph two brief sentences in execrable taste in praise of her late husband. Through the kindness of Mr. Livingston Wright, the author has seen the very copies of S. \& H. which Mr. Wiggin used in his revision, in connection with a MS. Mrs. Eddy furnished and therefore speaks with confidence. Mr. Wiggin, though discharging his full duty as a literary helper, never took Mrs. Eddy very seriously. In a letter in 1889 to a college friend he wrote of her as " an awfully smart woman, acute, shrewd, but not well read, nor in any way learned." She began to complain in 1890 of his "most shocking flippancy," and the relationship a little later was severed.

16. Mark Twain, 289. Nothing is more remarkable than Mrs. Eddy's steady growth in her old age in the art of literary expression. She has never wearied of working on S. \& H. Not a day passes, it is said, that she does not, even now, put some touch on her book. Her subjunctive once intractable, as is pointed out in McClure's, has grown obedient to her will. She no longer gives subjects to participles or antecedents to pronouns, and her 
tenses now stay where they belong. There is still vagueness in S. \& H., but in her recent public letters, barring an occasional hiatus of thought, there is much to justify Dr. Allan McLane Hamilton's judgment of Aug. 12, that " her mode of expression is logical and connected." C. S. Sentinel, Aug. 24.

17. Micou, 34. Professor George L. Cary calls C. S. "One Substance Pantheism."

18. R. \& I., 20.

19. Irving F. Wood, preface.

20. C. S. Sentinel, June 15.

21. S. \& H., Ch. XVII. See also the Expository Times, London, July, for article by Rev. H. W. Horwill on Mrs. Eddy's exegesis and Mr. Dixon's inadequate reply quoted in the C. S. Sentinel, Sept. 21.

22. S. \& H., 16, 533, 545, 538.

23. Mark Twain, 335-343.

24. Heine quoted in Farrar.

25. S. \& H. (1898), 154.

26. S. \& H. 12.

27. S. \& H. (1898), 476.

28. S. \& H. (1875), Chs. II \& IV.

29. S. \& H. (1898), 347.

30. S. \& H. (1898), 385.

As the author reads proof of these notes there comes from President David Starr Jordan of Leland Stanford University this confirmation of his judgment: "There is no element of permanence in the cult. I agree neither with the metaphysics nor with the English of Mrs. Eddy. The book and her whole doctrine are unintelligible. She has enthusiastic followers, to be sure, and they build huge temples, because there are many who like that which is unintelligible, and those same ones like to build temples just for the sake of building them."-The Congregationalist, Sept. 14.

\section{CHAPTER III}

1. S. \& H., 110, 107.

2. McClure's, Dec., 1906, 217. 
3. Quimby's Scrapbook.

4. McClure's, Feb., 348.

5. McClure's, Feb., 349.

7. H. W. Dresser, 53.

8. New York World, May 31, confirmed by George A. Quimby.

9. Letters from Mrs. Eddy to P. P. Quimby, which through the courtesy of George A. Quimby, the author has read in full. See also McClure's, Feb. 349, 350.

10-18. Quimby Scrapbook: McClure's, Feb. 345; April, 613 ; interviews with Dr. A. M. Cushing, Messrs. H. T. Wentworth and Richard Kennedy. Letters from above; also from Mrs. J. R. Walcott, Mrs. S. G. Crosby, and Mr. D. H. Spofford. Mrs. Eddy was then Mrs. Patterson but elected to be called Mrs. Glover. See also McClure's, March, 523, 520, 524. Mrs. Eddy's explanation that her letters to P. P. Quimby were written while she was under mesmeric influence will receive small consideration at the hands of the few, who like the author, have read not merely the extracts from them published in McClure's but also the originals in full.

19. H. W. Dresser, 120.

20. McClure's, March, 509.

21. S. \& H. (1888), 7 .

22. After a careful study of the Quimby Scrapbook, which has been in the author's possession for a month through the courtesy of Mr. George A. Quimby, the writer is convinced that it alone should suffice to close the case.

23. Sybil Wilbur in Human Life, April.

24. Evans, 209, 210.

25. George A. Quimby's refusal to accept Mrs. Eddy's proposition in the light of the Quimby scrapbook, Quimby manuscripts, and Mrs. Eddy's letters to Quimby, is entirely commendable as well as discreet, and incidentally, an apt illustration of "timeo Danaos et dona ferentes."

Edward J. Arens was once a devoted student and helper of Mrs. Eddy. In 1881 he published a pamphlet in which he quoted extensively from S. \& H. Mrs. Eddy brought suit in 1883 for infringement of copyright. Arens's defense was that he had borrowed from Mrs. 
Eddy's book what she had taken largely from P. P. Quimby's manuscripts. Neither being able to produce the manuscripts in court nor having access to them for comparison with Mrs. Eddy's book, Arens could not prove his case, and the court decided that he had violated Mrs. Eddy's copyright. The court did not pass upon the origin of Mrs. Eddy's ideas because the Quimby manuscripts were not in evidence, and without them the moral question involved could not be decided. Only the legal issue as between Mrs. Eddy and Arens was, or could be, settled by the court. Yet Mrs. Eddy has steadily construed the decision as a "vindication in the United States court" of her claim to be the originator of her healing principle, and her English representative, Mr. Frederick Dixon, in The American Queen for July, echoes her claim in a paragraph based on evident unfamiliarity both with the Quimby manuscripts and the details of the trial. See J. A. Dresser, 58; M. W., 249; McClure's, March, August, September.

26. The Committee claims to be able to support his statement by affidavits, and July 18th wrote the writer thus: "I have in my possession numerous statements and affidavits from reliable persons who were formerly treated by Mr. P. P. Quimby in 1861, and subsequent thereto. They invariably affirm that his treatment consisted of manipulations and that he never attempted to practice or teach any method of giving a mental treatment, and that he never ascribed the peculiar power he seemed to possess, to God. He regarded it as a natural gift and not the result of education." Having read, as the Committee has not, Mrs. Eddy's letters to P. P. Quimby, the Quimby scrapbook, and the Quimby manuscripts, the author is unable to imagine any evidence, past, present, or to come, which can seriously affect in any way the Quimby controversy. If, however, such evidence ever comes to light and proves on careful examination to be pertinent, specific, and authentic, the author will be prompt in admitting its significance and revising his estimate. He would like the reader distinctly to understand that he spared no effort to find all the evidence there is. If there still is 
evidence not considered in this volume the fault, as his voluminous correspondence proves, can not be charged to him. He repeatedly sought permission to make a careful study of the evidence the Committee claims to possess, but he always sought in vain; though the Committee was generous in giving information on other themes.

Mrs. Eddy has made much of Quimby's recognition of her aptness as a pupil and of her services to him. But teachers often speak in terms as glowing of their more promising pupils. Every right-minded teacher of the truth likes to regard himself as but a John the Baptist to the Christ that is to be. Undoubtedly Mrs. Eddy's newspaper tributes to Quimby did enlarge his reputation and bring him patients. But his son assures me that Quimby, like most busy men accustomed to receive effusive letters from the emotional, gave little heed to Mrs. Eddy's communications, and in his latter days concluded that she had " no identity in honesty."

The visits here referred to in the text are the ones mentioned in more inclusive terms in the Preface.

The following unexpected letter speaks for itself:

\section{Belfast, Maine,} Oct. 18, 1907.

My Dear Mr. Powell:

Having had the pleasure of reading so much of the proof sheets of your forthcoming book as relates to my father, I wish to express my pleasure at the way you have treated your subject, and also state, that the quotations you have made from his manuscripts, which you copied at my house, are absolutely correct, and were taken from his writings now in my possession. As you are aware, most of your extracts were written by him, prior to his acquaintance with Mrs. Eddy. Thinking that there might be some who would question the truth of your quotations, I have without any suggestion from you written this explanation which you are at liberty to use in any way you see fit. With kind regards, I am

Very truly,

Geo. A. Quimby. 
27. The author has consulted many of the witnesses who testify in both McClure's and Human Life and in every instance he has been informed that McClure's account is to be accepted. His investigation covers most closely the issues from January to July inclusive.

28. Mrs. Eddy did not originate the term "Christian Science." Abram Cowles used it in 1840. Rev. William Adams in 1850 published a book entitled Elements of Christian Science. I have found the term in the Quimby MSS. See H. W. Dresser, 239, 65, and McClure's, March, 513.

"Science of Health" sometimes appears in the Quimby MSS.

The ten quotations that follow in the parallel are from the MS. "Questions and Answers" which Mrs. Eddy used for years and habitually attributed to Quimby. A copy of this MS. with Mrs. Eddy's own interlineations in it is in the possession of Mr. H. T. Wentworth who has kindly shown it to the writer. It is almost word for word identical-the writer finds-with one of the Quimby MSS. written by P. P. Quimby, copied by his wife, and bearing a date several months before Mrs. Eddy's first meeting with Quimby. This MS., too, he has seen through the courtesy of Mr. George A. Quimby and McClure's magazine. The writer has copied from the other Quimby MSS. many pages of quotations which confirm those in "Questions and Answers," and leave no room to doubt that the MS. as it stands, with its introductory paragraphs and its interlineations is as Mrs. Eddy used to say, the output of Quimby's brain. Mrs. Eddy has made much of Quimby's failure to draw the distinction as sharply as she draws it between mind and matter. But Quimby's conception was more nearly Berkeleyan than Mrs. Eddy's. See James's Pragmatism, 89, and Hanna's C. S. History, 33.

The quotations from S. \& H. beginning with the third will be found in editions as follows: (1898), 543; (1881), 169; (1898), 449; (1898), 183; (1881), 169; (1898), 491, $513,466,478,62$. The "parallel" itself was first suggested by Peabody, $17 \mathrm{ff}$. 


\section{CHAPTER IV}

1. McClure's, Jan. 237, 238; Moll, $13 \mathrm{ff}$.

2. Mrs. Eddy's published reply to McClure's; Human Life, Feb.

3. R. \& I., 20 .

4. McClure's, Jan. 237, 241.

George Washington Glover disappears from his mother's life and seldom reappears till in 1907 he figures as one of the "next friends" in the suit of Mrs. Eddy vs. C. A. Frye et. al. For a while when a baby, he lived with his mother at his aunt Tilton's; then with the old nurse, with whom after her marriage he removed at the age of thirteen to Minnesota. He fought through the Civil War, became U. S. marshal, was prospector and miner for a time, and settled at last in Lead, South Dakota, where his mother built for him and furnished, in 1902, a comfortable house in which he still resides.

Influenced, Mrs. Eddy's friends claim, by those unfriendly to her, he and others brought suit as "next friends," March 1, to gain the legal right to represent her in the management of her property, which they asserted she was incompetent to manage. The suit was earnestly contested. While it was in progress Mrs. Eddy gave several interviews to newspaper reporters in which she appeared for a woman of eighty-six to be singularly vigorous in mind. The "Masters," too, had an important interview with her on Aug. 14th, in the presence of the senior counsel on each side. Two alienists of reputation, Dr. Allan McLane Hamilton and Dr. Edward French, engaged by Mrs. Eddy or her representatives, pronounced her competent to manage her affairs though their opinions were not published till after the suit was on August 21st abandoned by the "next friends." The result appeared to be a virtual victory for Mrs. Eddy. As this book goes to press a book is announced by R. D. Kathrens of Kansas City, claiming to give the inside history of the suit, but of the value of the book the author knows nothing.

5, 6. New England Magazine, March, 1888; H. W. 
Dresser, Chs. I and II; McClure's, Feb.; Arena, May, 1899; Boston Herald, Aug. 15. The facts concerning P. P. Quimby have been verified by his son, George A. Quimby.

7. J. A. Dresser. Mrs. Eddy had ample opportunity to become familiar with Quimby's ideas. She and other favourite pupil-patients spent many an hour with him after office hours asking him questions and encouraging: him to talk in his characteristic manner. His son gave me a vivid word picture of the unconventional doctor as in the late afternoon, wearied by the long day's work, he was wont to lie on his sofa in his office talking freely to the patients he knew best, two of whom were in those days copying the notes he happened then to be making.

8. C. S. Sentinel, Feb. 16, 1899.

There is another reason why Mrs. Eddy's claim cannot be substantiated. Though many of Quimby's characteristic phrases lodged in Mrs. Eddy's mind to be reproduced practically unchanged in her writings and to become current coin to-day among Christian Scientists everywhere, the difference in style between the Quimby manuscripts and Mrs. Eddy's writings is as marked as between Lincoln's Gettysburg address and S. \& H. The language of the Quimby manuscripts is direct. As one of his old patients writes me, "One didn't need a dictionary to understand Dr. Quimby." The language of S. \& H. is as already described in Ch. II. The difference is not alone in vocabulary and structure of sentences but also in the movement of the mind. Verbosity, vagueness, and overstatement are the "pinions"-quoting Mrs. Eddy's favourite word-of her wings (McClure's, Oct., 699), and Quimby, content to walk on the solid ground of clear and simple statement, never wanted to use wings.

9. Human Life, March; McClure's, February.

10. Dr. Cushing's affidavit is in McClure's, March, 511. The author had a personal interview with him May 8. See also Human Life, May.

11. Times Magazine, March; McClure's, April, 619; Sept., 532; Human Life, June.

12. The Stoughton sketch is based on correspondence and an interview of May 6 and its facts have been veri- 
fied by Mr. Wentworth and Mrs. Clapp. See also McClure's, April, 620-622; Human Life, May.

13. Quoted from an unpublished letter.

14. Letters from, and interviews with Richard Kennedy; also McClure's, May and July; Human Life, June and September.

15. R. \& I., 71. The "strange providence" apparently was a suggestion from Richard Kennedy that students would probably be more willing to pay a larger price for tuition than to mortgage their future by promising to pay Mrs. Eddy ten per cent. on all their future earnings.

16. McClure's, May, 103-5.

17. S. \& H. (1881), Vol. II, 34.

18. McClure's, May, 109.

19. In Human Life, Sept., p. 14, Mrs. Eddy's explanation is given of her break with Mr. Spofford. She puts it on the ground of his business incompetency and his desire to wrest from her the C. S. leadership.

20-22. Mrs. Eddy sometimes gives an uncommon or unwarranted import to ordinary words. See McClure's, July, 343, for instances of confusion of "immorality" and "disloyalty," "adultery" and "adulteration." All through the various editions of S. \& H., she frequently confuses "personality" and "corporeality" and sets up an antagonism between "personality" and "principle" as unnecessary as it is hurtful to her metaphysics. See McClure's, July, for full account of the witcheraft case; also McClure's, August; and Human Life, Sept.

23. R. \& I., 60. One of several who knew Mr. Eddy and have given me their recollections of him informs me that Mr. Eddy seemed to him slow and over-cautious, rather than naturally dull or stupid. He thought him completely overawed and benumbed by his wife's stronger nature. Dr. Patterson died in 1896.

24, 25. McClure's, May, 115, 116. The italics are Mrs. Eddy's.

26. The post-mortem examination of Mr. Eddy made at Mrs. Eddy's request by a reputable physician disclosed " organic disease of the heart, the aortic valve being de- 
stroyed and the surrounding tissue infiltrated with calcareous matter." To satisfy Mrs. Lddy the physician showed her the heart, and yet she still insisted that her husband had died of "malicious mesmerism" or "arsenical poisoning mentally administered."-McClure's, Sept., $568 \mathrm{ff}$. See also R. \& I., 60.

27. McClure's, Sept., 572-5; Human Life, Jan.; C. S. Sentinel, May 23, Aug. 24; Philadelphia North American, July 15.

According to McClure's, Sept., Calvin A. Frye was born Oct. 24, 1845, in Frye village, now a part of Andover, Mass., of good New England ancestry. His father, Enoch Frye, was graduated from Harvard in the famous class of 1821, which numbered Emerson among its brightest stars. After attending public school in Andover he worked in a machine shop till in 1882 at the age of thirtyseven in response to a telegram he entered Mrs. Eddy's service, in which for a quarter of a century he has been engaged, it is said, without vacation. He has at times done her marketing; kept her books with honesty she testifies, and the recent auditor of his accounts reports; written many of her letters, and, dignified New Englander as he is, these many years clad in livery he has sat upon the coachman's box when she has gone out for her daily drive. He has been faithfulness itself to her and to her interests because according to his affidavit he has steadily believed both in her and in her theory. In an anomalous position, under frequent criticism and not infrequent ridicule, he has for a quarter of a century hid behind an impassive countenance and an unbroken silence, his motives, feelings, and experiences.

28. R. \& I., 62; McClure's, Aug.

29. Robinson, 13. The references in the preceding paragraph are to McClure's, Sept., 581.

Not all who heard Mrs. Eddy in those days were impressed alike. Miss Frances J. Dyer, trained journalist, frequently attended C. S. services in the early eighties and has kindly revived for the writer's use the following recollections written at the time:

Among the novel Sabbath services in this city of 
heterodoxy is the gospel according to Mrs. Mary B. G. Eddy, the chief apostle and expounder of "Christian Science," so called. In Hawthorne Hall, at three o'clock on Sunday afternoons, an audience of some 200 intelligent and respectable looking people assemble to listen to their "pastor." The exercises begin with singing a hymn. Then follows a moment of silent prayer, and a most remarkable paraphrasing of the Lord's Prayer. After each petition by the audience Mrs. Eddy interjects one of her own. For example, after the people say, "Thy will be done," she adds, "May the supremacy of spirit appear, and the dream of matter disappear." "Lead us not into temptation" is followed by "Deliver us from the errors of personal sense." The sermon on the last Sabbath chanced to be an exposition of the fourteenth of John. The first two verses were read, and questions asked: "What is meant by the heart physically and metaphysically?" Timid voices replied, "A bodily organ" and "The seat of the affections." After a little preliminary skirmishing of this sort, the speaker plunged boldly in medias res as set forth in a written manuscript, and elucidated the doctrine of original sin by stating that " man and God are co-existent and eternal; losing our sense of this, we gain our mortal sense, and thus become sinners." If we listen to the realities of $\sin$ as preached from modern pulpits we are hell. This is metaphysics. When all our sense of being goes into the spiritual, then only do we begin to live. Our only intelligence and substance is an apprehension of the great and eternal somethingness. Jesus, the great metaphysician, whose mission is to turn away our thought from a personal Satan and a personal sinner, is simply the idea of the divine intelligence which we call God, or good. Christ always employed mental methods for bodily healing. We are what we think we are, and our attitude of thought determines our bodily condition. There is no such thing as matterall in the universe is spirit. And so on, ad absurdam. Meetings have just been suspended, however, owing to a "pressure of other duties."

The fountain head whence these amazing sophistries 
are promulgated is the Metaphysical College, a chartered institution at 571 Columbus Avenue, and students flock there by the score, even at the exorbitant charge of $\$ 300$ for twelve lessons. Here may be found several other resident "physicians" and elsewhere in the city are a dozen others, most of the practitioners being women. A Journal of Christian Science is published every other month. Some of the printed testimonials therein to Mrs. Eddy's book, Science and Health, with Key to the Scriptures, give somewhat doubtful praise. Witness, for instance, this one from Longfellow:

"Having so many occupations and interruptions, I have not found time to read Science and Health sufficiently, but will not on that account delay thanking you for its excellence."

30. McClure's, Sept., 575; May, 1899.

31. Arena, May, 1899.

32. See statement of " next friends" in lawsuit.

33, 34. R. \& I., 67; M. W., 271-274; R. \& I., 67-72; Hanna, 40; Clark, 115.

35. P. \& P.; Peabody, 40; M. W., 140.

36. M. W., 139-143, 156; also private letter of June 30, 1890.

Christian Science architecture is distinctive. Calm and dignity, beauty and harmony are the ideals it endeavours to embody. Of Gothic, Christian Scientists will have nothing because Gothic is too closely associated with historic Christianity. They go back to Athens and the Acropolis not only because-to quote the architect of the Boston Church_it is "based on a mathematical inerrancy which is most fascinating to analyse" but also because " the purest type of the ancient Greek temples was the outgrowth of a naturalistic and rationalistic religion."-S. S. Beman in The World To-day, June, 582-590.

37. There are many likenesses between Mrs. Eddy and Mahomet in temperament, character, and career. See Stanley Lane-Poole, V-LV for analysis of Mahomet.

38. Letter from the Committee on Publication, dated June 20.

39. The Committee adds that "the most significant 
item bearing on this point is the fact that there are nearly 450,000 copies of Science and Health in use. If there are two copies in the average family of five this would mean more than a million persons studying the book."

Apparently, however, the Committee has for the moment forgotten that according to the C. S. Q. Bible Lessons no copy of Science and Health before the 226th edition can be used in following the Sunday services, and that there is for this reason and other reasons, constant encouragement given to Christian Scientists to buy new editions. The latest edition, published in September, containing a portrait-made many years ago-of Mrs. Eddy, is so alluringly advertised that every Christian Scientist will want to buy a copy. A Christian Scientist near Mrs. Eddy has in fact stoutly asserted to me that no one should read any but the latest editions. A considerable number of copies must be also in the libraries, and some at least in the hands of those whose only interest is curious or critical.

40. For illustrations see McClure's for the current year and the C. S. Sentinel, July 27, p. 910. Note also: "At the written request of the Pastor Emeritus, Mrs. Eddy, the Board of Directors shall immediately notify a member of this Church to go in ten days to her, and it shall be the duty of the member thus notified to remain with Mrs. Eddy twelve months consecutively or three years consecutively if Mrs. Eddy requires or requests it. A member who leaves her in less time without her consent or who is discharged, shall be dropped from the Church. Male members who remain with her three years consecutively, shall be paid semi-annually at the rate of twelve hundred dollars yearly in addition to rent and board. Female members shall receive one thousand dollars annually with rent and board. Those members, whom she teaches the course in Divinity, and those who remain with her three years, receive the degrees of the Massachusetts Metaphysical College."-Manual, 66.

41. Manual, 18, 3.

42. Mark Twain, 209. 
43. William P. Trent.

44. Alfred Farlow.

45. C. S. Sentinel, July 6, 852 .

46. Boston Herald, Aug. 17.

47. Human Life, July.

48. The case in question was that of the Aberthaw Construction Co. vs. Carpenters District Council of Boston and Vicinity and the Christian Science Church (Owners). The case was first referred to a "Master," Hon. Wade Keyes; and when objections and exceptions to his report were filed by the Christian Science Board of Directors, his decision after full argument was " unanimously sustained by the Court of Last Resort of the Commonwealth of Massachusetts," March 27, 1907. The report of much of the evidence and the court decision have been printed for distribution by the Master Builders Association of Boston in a pamphlet, loaned the author by Mr. W. L. Cook and closing with the following words: "The amount of money involved in this case was insignificant, but the principle was great, and the decision rendered is so important and far-reaching that all parties concerned in industrial issues should take note thereof." See also editorial in the Springfield Republican, June 20. McClure's, August, gives other instances of litigation in which Mrs. Eddy has been involved from time to time. The explanation in Human Life, Sept., that others have been in every case at fault is not convincing.

49. Private letter dated Dec. 18, 1890. See McClure's, Oct., 688, for instance in which Mrs. Eddy claims "divine origin" and, 692, for instance in which Mrs. Eddy admits to the Journal, May, 1885, while she was actual editor, the following claim a disciple makes for her: "She existed from the beginning before all ages, and will not cease to exist throughout all ages."

50. Notes to Chapter II, 2.

51. McClure's, Sept.

52. New York American, Aug. 26.

53. Punch's phrase applied without disparagement to Mr. Gladstone as it is here to Mrs. Eddy. 


\section{CHAPTER V}

1. S. \& H. (1898), 464; Sturge, 14, 15; Karl Pearson's Ethic of Free Thought; J. R. Mosley in Cosmopolitan, July, 331.

2. S. \& H. (1898), 481.

3. Cosmopolitan, July, 333.

4. A Critic Answered, $13 \mathrm{ff}$.

5. Peabody, 29; McClure's, Aug., 457.

6. Canon Scott Holland in Sturge, XVIII.

7. The successive editions of S. \& H. were numbered until the 440th appeared a few months ago. The numbering was then discontinued.

8. Lodge, VI.

9. A Critic Answered, 16. To understand the unwarranted appropriation made by C. S. of the word "reality" to a special meaning, see James's Pragmatism, 212, 244. 10. S. \& H. (1898), 110, 170, 189, 484. Since writing the paragraph to which this refers the author has found a full description of Soul Senses in a Quimby manuscript dated May, 1860.

11. Frothingham, 122-127.

12. H. W. Dresser, 97-100.

13. Collect for first Sunday in Lent.

14. Peabody, 34. This was verified by personal letter.

15. S. \& H., 331 .

16. Newman's Apologia, 144.

17. A Critic Answered, 14.

18. S. \& H. (1898), 129.

19. S. \& H., 172.

It is profitable to compare Mrs. Eddy's crude view with the concept of a trained scientist like Sir Oliver Lodge: "The popular misconception concerning the biological origin of man, that he is descended from monkeys like those of the present day, is a trivial garbling of the truth. The elevated and the degraded branches of a family can both trace their descent from a parent stock; and though the distant common ancestor may now be lost in obscurity, there is certainly in this sense a blood relationship between the quadrumana and the bimana: a relationship 
which is recognised and is practically useful in the investigations of experimental pathology."-The Substance of Faith, 17.

20. Christian Science: Humanity's Helper, 17. The verse which appears immediately before the quotation of Professor Hering's is from a poem by Professor W. H. Carruth.

21. Compare with Mrs. Ward's noble words in David Grieve, 402, the following doggerel Mrs. Eddy offers in protest against evolution:

"Thenceforth to evolution's

Geology, we say,-

Nothing have we gained therefrom,

And nothing have to pray." $-M$. $W$., V.

22. Cushman, 58, confirms the writer's thesis in his forceful phrase definitive of C. S.: "It is theoretical moral anarchism." It has also been admitted by a prominent official of the Church that C. S. is "essentially individualistic" in opposition to the socialistic tendencies of the time. See Human Life, January 4.

23. S. \& H. (1898), 223.

24. S. \& H. (1875), Ch. I.

25. Hutchinson, 32 .

26. Wright, 18, 19. Also Ch. IV, note 26.

27. S. \& H. (1875), Ch. I.

28. S. \& H. (1898), 290.

29. Cambridge Chronicle, Nov. 3, 1906.

30. S. \& H. (1898), 316.

31. S. \& H., 140.

32. S. \& H., 142.

33. S. \& H. (1898), 21.

34. S. \& H., 126.

35. S. \& H., 141.

36. Prayer Book, 38.

\section{CHAPTER VI}

1. S. \& H. (1898), 461.

2. S. \& H. (1881), I, 167; II, 97.

3. Northampton Herald, Oct. 16, 1905.

4. C. S. v. P., 5, 12. 
5. S. \& H. (1898), 7.

6. S. \& H. (1888), 50 .

7. Hutchinson, 16.

8. Cosmopolitan, July. It is gratifying to find Mr. Farnsworth (Arena, July, p. 59) thus confirming the writer's view of the tendency of C. S. to turn to dualism: "Christian Science . . drops upon investigation into a dualism because its utter inability to account for mortal mind and that error of mortal mind the inharmonious, phenomenal world of sense, argues the existence of an evil principle at war with God."

9. Living Church, July 6, 339. A writer in the C. S. Sentinel, Sept. 21, p. 57, apparently does not endorse Mr. Farlow's explanation. She writes: "Principle and not personality is the only foundation upon which we can build safely."

10. The italics are the writer's.

11. Letter dated May 31.

12. S. \& H., 6.

13. S. \& H., XI.

14. S. \& H., 331. The more specific statement appears in S. \& H., 55: “In the words of St. John, ' He shall give you another comforter, that he may abide with you forever.' This Comforter I understand to be Divine Science."

15. Fluno, 23. Throughout a paragraph C. S. is identified with the Holy Spirit.

16. S. \& H. (1898), 469: See also M. W., 63.

17. H. W. Dresser, 109, 94. In the Quimby manuscript dated May, 1860, there is also a clear statement of the case.

18. Quimby Scrapbook.

19-21. S. \& H. (1898), 1, 532, 229. Farnsworth in Arena, July, 60.

22. C. S. Sentinel, June 15, 1899, 6.

23. The note is dated Dec. 22, 1906, and appeared in the C. S. Sentinel.

24. S. \& H. (1898), 513.

25. S. \& H. (1898), 550-7. The italics are the writer's. 
26. Searchlights, 45. Mrs. Eddy once at least calls Jesus the "Way-shower." See M. W., 30.

27. R. \& I., 95 .

28. S. \& H., 569.

29-31. Mark Twain, 334-8; Manual, 63.

32. McClure's, March, 507.

33. McClure's, July, 337.

34. Peabody, 26.

35. Manual, 94, reads: "If the author of the Christian Science text-book call on this Board for household help or a handmaid, the Board shall immediately appoint a proper member of this Church therefor, and the appointee shall go immediately in obedience to the call. "He that. loveth father or mother more than me is not worthy of me." (Matt. 10:37).

36. M. W., 309 .

37. S. \& H. (1875).

38. Lodge, 125.

39. S. \& H., 15. Mrs. Eddy's entire theory of prayer, even to her warning against audible prayer, will be found substantially in Quimby's language in the Quimby manuscript dated March, 1860.

40. Cambridge Chronicle, Nov. 3, 1906.

41. S. \& H., 16.

42. Lodge, 129 .

43. Mt. 28:29; I Cor. 11:23-25.

44. S. \& H., 32 .

45. S. \& H., 35; Arena, May, 1899, 564.

46. S. \& H. (1888), 504.

47. S. \& H., 35.

48. S. \& H., 34. For a scientific statement of the necessary sacramental relationship of mind and matter, see Thomson, Chs. II. and VIII.

49. Cushman, 35; S. \& H. (1898), 468.

50. A Critic Answered, 19. In the Quimby manuscript dated July, 1860, the statement is made that God did not create evil.

51. Browning's Abt Vogler.

52. Campbell's New Theology, 52.

53. S. \& H. (1898), 7. 
54. Isaiah 45:7; Genesis $1: 31$ and 1:18.

55. S. \& H. (1898), Index on Sin.

56. Rev. C. E. Holmes, Ph.D.

57. Professor Cushman (58) sums up the tendency of Christian Science to confuse moral distinctions in this way: "To deny the existence of sin is to deny the existence of virtue; and to disallow disease is to disallow health. There cannot be good without ill, virtue without sin, health without disease, knowledge without ignorance, heat without cold, white without black. These are correlative terms. They are as mutually necessary as one pole of a magnet is to the other. To deny sin and disease is to deny all moral distinctions whatsoever, and upon moral distinctions is society built."

Professor Barrett Wendell in his France of To-day (177) notes the same tendency to deny facts and thus to confuse moral distinctions among Christian Scientists in his treatment of the Dreyfus case.

The writer knows a clear-headed woman who declined to become a student of C. S. because she was required at the beginning to endeavour to persuade herself that black is white.

58. S. \& H. (1898), 38, 443, 486, 588, 589.

59. Human Life, July.

60. S. \& H. (1898), 639-641; (1888), 515.

61. Alfred Farlow in the Boston Post, July 2; S. \& H. (1875).

62. McClure's, May, 116.

63. Omaha Daily News, January 7 and 8, 1901.

64. The paragraphs above were written before Mrs. Eddy's disavowal, Aug. 14, of belief in the power of one mind to work ill to another and before Dr. Allan McLane Hamilton, going far beyond the province of an alienist, declared that "the allegations concerning Mrs. Eddy's belief in 'malicious animal magnetism' are ridiculous." I am allowing the paragraphs, however, to stand in proof because the evidences presented in S. \& H. (especially the third edition), in certain personal letters of Mrs. Eddy with which Dr. Hamilton cannot have been familiar, and in the conversations and correspondence I have had 


\section{Notes}

-and Dr. Hamilton has not-with those who have known her during a considerable period of her career leave no room to doubt the large and lurid place "M. A. M." has had both in her outward and her inner life. If she no longer believes in it, Mrs. Eddy deserves to be congratulated on her escape, though late, from the thraldom of an actual obsession. But that in no wise alters the evidences of the past. See also McClure's, May to October, and Boston Herald, Aug. 17, in which appear several significant letters.

\section{CHAPTER VII}

1. Hudson, 7, 8.

2. S. \& H., 107, 120. In the "Masters" interview of Aug. 14th Mrs. Eddy said in explanation of her healing system: "When I came to the point that it was mind that did the healing, then I wanted to know what mind that was. Was it the mind which was in Jesus Christ, or was it the human mind and human will? Then I went to investigating spiritualism and mesmerism and hypnotism, to see if I could find out, and I did n't find God there; therefore I turned to God in prayer and said: "Guide me, guide me to that mind which is in Christ," and I took the Bible and opened it at the words, "Now go write it in a book." I can show you where it is in the Bible. I then commenced writing my consciousness of what I had seen, and I found that human will was the cause of disease instead of its cure; that hypnotism and mesmerism or human concepts did not heal-they were the origin of disease instead of its cure; and that the divine mind was the healer, and then I found it through the Scripture. "He healed all our diseases. Go into the field, preach the Gospel, heal the sick," and I felt there was my line of labour, and that God did the healing, and I could no more heal a person through mortal mind or will power than I could heal then by cutting off their heads, and I could not heal them by it, for I don't know how to use will power to hurt the sick; I don't know how to do it."-Boston Herald, Aug. 15. 
3. S. \& H., 149; (1898), 426; Oughton, 98; Alfred F'arlow in the Boston Herald, July 18. I give Mr. Farlow's report of Mrs. Eddy's statement as she recalls it as to stopping the bleeding of her arm. Dr. Edward Everett Hale, to whom she made the statement, wrote me Sept. 27: "Mrs. Eddy said to me that I might cut through the main artery of her arm and that she would stop the effusion of blood by an exertion of will."

4. S. \& H. (1898), 422, 423, 47, $217,374,375,385,421$, 485.

5. Snyder, 11; C. S. Legislation, 18; Broadway Magazine, May, 163; Casson, 35.

6. Muldoon, 30. Mrs. Eddy admitted over her own signature in the Boston Herald, Dec. 2, 1900, that she allowed a dentist to use his painless method in the extraction of her tooth.

7. Muldoon, 31. For an important correction of Mrs. Eddy's reference to Berkeley, see James's Pragmatism, 89.

8. S. \& H., 179. Absent treatment was an implication of Quimby's healing theory which especially appealed to Mrs. Eddy. After she left him in the autumn of 1862 she was, as I found in her letters to him, ever visualising him. Once she wrote that she had actually seen him spiritually present. Again, she besought him to visit her in his "omnipresence." Once she wrote of him as "Comforter" and of his "angel visit" to her. She developed a truth he taught her but it was none the less a truth of his discovering.

9. S. \& H., 177, 178.

10. S. \& H. (1888), 451; S. \& H., 401.

11. Government, 4.

12. S. \& H., X.

13. Osler, 382.

14. Dr. Huber confirms my references to him and in a letter, dated Aug. 22, adds that he found the C. S. claims in the instances cited to be "pitifully without foundation."

15. Goddard, 433-7.

16. S. \& H., VIII; (1898), 290.

17. Oughton, 85; Casson, 180. 
Mrs. Eddy says: "Sickness has been fought for centuries by doctors using material remedies; but the question arises, Is there less sickness because of these practitioners? A vigorous ' No' is the response deducible from two connate facts,- - the reputed longevity of the Antediluvians, and the rapid multiplication and increased violence of diseases since the flood."-S. \& H., VIII.

Mrs. Eddy often betrays her unfamiliarity with history, archæology, geology, and Biblical criticism as in the above passage. But one would not press a tactical advantage.

It is difficult, however, to withhold comment from the following sentence: "The census since 1875 (the date of the first publication of my work, Science and Health) shows that longevity has increased."-M. W., 20.

18. Seaman and Suzuki in Review of Reviews, Nov. 1905.

19. Keen, 217-261.

20. S. \& H. (1898), 214, 622, 381, 382, 387, 388, 411.

21. Oughton, 83 .

22. S. \& H., 111.

23. Osler, 302. It would seem pertinent also to inquire whether C. S. can cure pleurisy, since in the recent lawsuit it was admitted, Aug. 8, that Joseph Armstrong, Mrs. Eddy's publisher and conspicuous supporter, was under treatment for pleurisy by a regular physician. Says the Boston Herald, Aug. 9, in editorial comment: "The turning of publisher Armstrong of the Christian Science coterie of officials to a physician for treatment for pleurisy is as if John had been like Judas, as if Melancthon had left Luther to serve Leo $\mathrm{X}$, as if John Knox had fallen under the spell of Queen Mary's blandishments and turned Roman Catholic, as if Asbury and Coke on arriving in America had preached Calvinism, and as if a speaker at Northfield should preach agnosticism."

24. S. \& H., X.

25. S. \& H. $(1898), 367,378,383,416,485$. The article on C. S. cures in the Broadivay Magazine for November seems to the author negligible in the light of the tests he speaks of in the preceding paragraphs and to which the alleged cures have not been subjected. 
26. S. \& H., 110; (1898), 42, 368, 369.

27-30. S. \& H., 515, 396, 399, 411, 412, 421.

"Chemicalisation" is coin strange enough to come from Mrs. Eddy's mint. But George A. Quimby incidentally remarked, July 16, to the writer that his father was constantly speaking of the "chemical change" which his ideas produced in patients. "He never sat down by a patient," said his son, "but he used this phrase. Never!"

The writer has also found the phrase "chemical change" in the Quimby MSS. dated March, April, and October, 1860,-two years before Mrs. Eddy's first visit to Quimby.

31. S. \& H., $427,428$.

32. Hutchinson, 17.

33. S. \& H. (1898), 343, 358.

34. Heber Newton, in Mark Twain, 322-7; Schofield, Ch. II; Huxley, 84-96; Zola's Lourdes; Oughton, 26-32.

35. Goddard, 442-5.

36. Goddard, 472 .

37. Goddard, 473; Moll, 389; Bramwell, $161 \mathrm{ff}$.

38. The Emmanuel Movement was started and is today conducted by Rev. Elwood Worcester, Ph.D., D.D., Rector of Emmanuel Protestant Episcopal Church, Boston, assisted by Rev. Samuel McComb, D.D. For further account of the Movement see The Homiletic Review, Sept.; The Open Court, Sept.; The New York Evening Post, March 30; The Congregationalist, April 6; Good Housekeeping for March, April, Oct., and Nov.; and Harper's Bazaar, October. See also The Christ that is to be, 215274 , for detailed consideration of the possibilities and duties of the Christian church in healing the sick.

The author does not discuss the possibility of the cure of organic diseases by suggestion. He is acquainted with the argument for it in Schofield's Forces of Mind, 164, and in The Christ that is to be, 215-225. But he believes it is too early to determine to what extent suggestion is applicable beyond the range of nervous and functional disorders. He welcomes experimentation but thinks it ought to be made with caution, under proper conditions, and that scientific tests should be applied before and after. The methods of C. S., especially with 
children, seem to him reprehensible and deserving of state regulation.

39. Goddard, 485.

40. Ch. III. Note 24.

41. Arthur Hugh Clough.

\section{CHAPTER VIII}

1. M. W., 52 .

2. M. W., 288.

3. The latest concrete instance appeared in the following open letter in the Boston Herald, July 11:

\section{A DIVIDED FAMILY}

To the Editor of The Herald:

In your issue of July 5th, you published a letter from Mr. Alfred Farlow regarding the "Case of Prof. Hart." In this letter Mr. Farlow says, "The habit of charging one's family troubles to Christian Science or some other religion has become about as common nowadays as . . . when, in fact, these quarrels are due to a want of Christian Science," and Mr. Farlow also goes on to say, "It seems to us that if there are any inviolable rights, whether they concern a husband or a wife, it is the individual choice of religion and medicine. There is no more reason why a husband should dominate the religious belief of a family than that a wife should regulate it, . . . the only just and perceptible means of harmony in the home regarding religious beliefs is to leave each member in the unmolested entertainment of his own faith."

I agree with Mr. Farlow that it is right and proper to leave the husband or the wife to the unmolested entertainment of their own views, but how about a family of children aged from 8 to 16 years; I am the father of such a family, and my wife became interested a few years ago in Christian Science. Now during all our married life we have had a home in which harmony reigned, our chief desire being to have a home for our children in every sense of the word, my wife has always been a devout Christian woman and a good mother, and I am old fash- 
ioned enough to be passionately in love with her, therefore when she became interested in Christian Science I at once took up the study of it with her, attending the church and lectures, following the various lessons, etc., etc., with the result that my wife accepted Christian Science in all its teachings and I rejected it, while admitting that the idea back of it (which is in all religions) is good. Then the first inharmonious note appeared in our home. I do not desire my children to become Christian Scientists and my wife does desire it with her whole heart. Who is to give way, my wife or myself?

My wife has had so-called "claims" and has been in practitioners' hands, to whom she has explained my position in the matter. The practitioner failed to relieve my wife of her "claims" after "treating" her for a time, and then declined to treat her further, owing to her husband's (the writer's) thought being so much opposed to Christian Science. I presume this opposing thought of mine is another phase of malicious animal magnetism, which (if my presumption is correct) demonstrates the fact that Christian Science is not all powerful to protect from every evil, $i$. e., opposing thoughts.

Now, it looks to me as if my family was split wide open, and the split getting wider, not through want of Christian Science, by any means, but entirely through its presence. Yours truly,

Brookline, July 8, 1907. J. R. D.

4-9. S. \& H. (1875), Ch. VI; S. \& H., 64, 65; M. W., 286 ; S. \& H., 64.

10. St. Luke 20:34; St. Matthew 22:30; St. Mark 12:25. See Bruce in Expositor's Greek Testament and Plummer in the International Critical Commentary on St. Luke.

11. I Thess. $4: 16 \mathrm{ff}$.

12. "We do not question the authenticity of the scriptural narrative of the Virgin Mother, and Bethlehem Babe, and the Messianic Mission of Christ Jesus: but in our time no Christian Scientist will give chimerical wings to his imagination, or advance speculative theories as to 
the recurrence of such events."-R. \& I., 95. And yet in 1906 we find Mrs. Eddy writing: "Gender also is a quality, a characteristic of mortal mind, not of matter." -S. \& H., 305.

13-19. S. \& H. (1875), 122; S. \& H. (1881), II, 160; S. \& H. (1888), 152, 162; S. \& H. (1898), 33, 541; S. \& H. (1906), 68,69,548. This reference to the butterfly and bee is omitted from the edition of September, 1907, but in its place appears a statement apparently meaning the same thing.

20. Manual, 100.

21. The writer is indebted for his facts about the Sunday-school to an usher of the Boston Church who one Sunday morning kindly acted as his guide through the colossal church before the appointed hour of service.

22. Richardson. A man formerly high in C. S. circles writes: "It is an actual fact that if those holding prominent positions in the church and are fired by ambition to rise higher in executive control are blessed with children, they will be looked upon with disfavour. Such domestic blessings are contrary to the process of spiritual refinement promulgated by the pastor emeritus. That accounts for the deploringly low birth rate among Christian Scientists."

See also Edward C. Farnsworth and John B. Willis in the Arena for July. To Mr. Farnsworth's charge that the goal of C. S. is sexlessness, which Mrs. Eddy's sentence, "Spirit will ultimately claim its own, all that really is, and the voices of physical sense be forever hushed" (S. \& H., 64) clearly confirms, Mr. Willis feebly cites in refutal various passages to prove that "virtue consists not in abstaining from vice, but in not desiring it,"which is not the point at issue, which is in fact a commonplace of Christian ethics.

No one can read Jane Addams's article in the Ladies' Home Journal, September, on "Why Girls Go Wrong" without perceiving the social peril lurking in Mrs. Eddy's unsacramental view of marriage.

23. M. W., 289.

24. Manual, 100. 
25. S. \& H. (1898), 336.

26. S. \& H. (1898), 162.

27. M. W., 151 .

28. S. \& H. (1875)

29. S. \& H. (1898), 385.

30. C. S. Journal, April, p. 17.

31. See Paul Elmer More (8) for picture of the perils of abstract affection.

32. Arthur Hugh Clough.

33. William Rathbone Greg, quoted in Snyder, 16. 


\section{INDEX}

A

Abbott, Dr. Lyman, 19

Abdera, 108

Aberthaw Construction Co., 238

Absent treatment, 246

Adam, and mental surgery, 176

Adams, C. F., 5

Adams, Rev. Wm., 231

Addams, Jane, 251

Advertiser, the Portland, 40

Agamogenesis, 211

Ambrose, 192

Amesbury, 69

Amram, 120

Anarchy, and Christian Science, 11, 130, 134, 217, 241

Anaxagoras, 128

Ancrum, 129

Animal magnetism, see Magnetism.

Animals, Christian Science healing of, 174

Anne, Queen, 193

Apostolic age, 8, 10

Arabian Nights, 91

Architecture, Christian Science, 237

Arens, E. J., 46, 80, 228

Armstrong, Joseph, 248
Asceticism, 204

Athanasius, 192

Augustine, 192

Austen, Lady, 63, 64

B

Baker, Albert, 52

Baker, Mark, 52, 53

Baker, Mary A. Morse, 52;

see Mrs. Eddy.

Banner of Light, 70

Baptism, Mrs. Eddy on, 159

Baptists, 193

Barker, Dr. L. F., 198

Bede, 192

Berkeley, 59, 109, 174

Berne, 60, 196

Bernheim, 60, 196

Bible, and Science and Health., Ch. II; P. P. Quimby and, 59; on evil, 163

Birth, Virgin, 207

"Black Death," 181

Blumhardt, Parson, 193

Braid, 51

Brain diseases, 173

Bramwell, 201

Bright's disease, 174

Brookins, Miss, 132, 157

Brooks, Phillips, 120 
Browning, Robert, 163

Bryce, James, 87

Buckley, Dr. J. M., 19

\section{C}

Campbell, R. J., 163

Cancer, 172, 173, 177, 184

Canterbury, N. H., 51

Carruth, W. H., 126

Catharine of Siena, 193

Celibacy, 204

Chalcedon, Council of, 143

Charcot, 194

Charlemagne, 192

Charles II., 193

Chase, S. P., 72

Chemicalisation, 189

Childbirth, and hypnotism, 197

Chiniquy, Parson, 193

Choate, Mrs. Clara, 87

Christ and Christmas, 153

Christ, Mrs. Eddy's conception of, 143, 191; see also Jesus.

Christian Science, see Table of Contents.

Christian Science Association, 21, 86, 151

Christian Science Journal, 88 Christian Science Quarterly, 88

Christian Science Sentinel, 88 Christian Science versus Pantheism, 137

Christian Scientists, and Christians, Ch. I; total number of, 96

Christians, and Christian Scientists, Ch. I
Christianity, apostolic, Ch. I ; and mental healing, 197

Chrysostom, 192

Church, apostolic, and mental healing, 192

Church, Mother, in Boston, $3,95,96,103,211$

Church, the, and Christian Science, Ch. I

Civil War, 58

Clapp, Mrs. C. I., 69, 71

Clarkson, Judge, 168

Clemens, S. L., 14, 15, 19, 27, 151

Clough, Arthur Hugh, 202, 216

Comforter, see Holy Ghost. Committee on Publication, 99, 176, 222, 237; see also, Alfred Farlow.

Comtism, 77

Concord, Mrs. Eddy at, 74, $94,95,98,126$

Constantinople, Council of, 143

Consumption, 172

Cosmopolitan, The, 126

Cowles, Abram, 231

Cowper, 63, 64

Crafts, H. S., 33, 69

Crosby, Mrs. S. G., VI, 30 , $34,35,46,58,105$

Cushing, Dr. A. M., VI, 33 . 66-68

Cushman, H. E., 241, 244

Cuthbert, 192

Cyril, 192

\section{D}

Darwin, 125

D’Aubigné, 193 
Davis, A. J., 51

Davy, Sir Humphrey, 193

Democritus of Abdera, 108

Demonology, Mrs. Eddy's, 166-168

Dentistry, 174

Devil, Mrs. Eddy's, 166-8

Diabetes, 185

Diagnosis, 176, 197

Dickens, Charles, 70

Dionysius, 163

Diphtheria, 172, 181

Disease, and Christian Science, 172

Divorce, 204

Dixon, Frederick, 229

Doctors, Mrs. Eddy on the, 131

Dods, J. B., 51

Dowie, 194

Dresser, H. W., VI, 31, 32, 61, 63

Dresser, J. A., 43, 46, 61, 62

Dresser, Mrs. J. A., 31, 46

Drugs, Mrs. Eddy on, 131,166

Drummond, Henry, 26

Dualism, 139, 143

Dubois, Dr. Paul, 60, 196

Dunmore, Earl of, 16

Dyer, Miss Frances J., 235

\section{E}

East Stoughton, 69

Eddy, Asa Gilbert, 80-84, $86,152,167,234$

Eddy, Mrs. M. B. G., see Ta-

ble of Contents; also, Ba-

ker, Glover, and Patterson. Eddy vs. Frye et al., case of, 16,85
Edmonton, 63

Edwards Church, the, 132

Eginhard, 192

Eliot, Prest. C. W., 9, 129

Elizabeth, Queen, 107

Ellises, the, 33, 68

Emerson, R. W., 109, 119

Emmanuel Movement, 197 248

Encyclopedia Britannica, 112 Ephesus, Council of, 143

Esdaile, 197

Estate of Mrs. Eddy, 224

Eucharist, the, Mrs. Eddy on, 161

Evans, Dr. W. F., 43, 46, 202 Eve, and mental surgery, 176

Evil, see Sin.

Evolution, 124, 125, 241

Exegesis, 20

Exodus, 120

F

Family, the, and Christian Science, Ch. VIII

Farlow, Alfred, VI, 92, 100, $111,114,115,116,117$. $122,124,140,162,171$, 176,249 ; see also Committee on Publication.

Farnsworth, E. C., 135, 242, 251

Fehling's test, 185

Fevers, 173, 186

Fluno, Dr., 142

Foster-Eddy, Dr. 85, 91, 167 Free Press, the Lebanon, 39 French, Dr. Edward, 85, 232 
Friendship, and Christian Science, Ch. VIII

Frye, C. A., 84, 85, 92, 235

G

Gautama, 108

Gender, Mrs. Eddy on, 251

Gladstone, 182

Globe, the Boston, 85

Glover, G. W., 55, 232

Glover, Mrs. Mary B., 40; see also Mrs. Eddy

Gnostics. 216

God, and evolution, 123; Mrs. Eddy's conception of, 136, 150, 187, 215

Goddard, Professor H. H., 178,194

Gordon, Dr. George A., 19, 129

Gould, Helen, 184

Greg, W. R., 219

Gregory the Great, 192

Grieve, David, 129

Grimes, 51

\section{$\mathrm{H}$}

Hale, Dr. Edward Everett, 246

Hamilton, Dr. Allen M'Lane, $85,222,227,232,244$

Hamlet, 113, 209

Hanna, Judge, 173, 177, 178, 224

Hawthorne Hall, 89

Healing, Christian Science, Ch. VII

Healing, mental, Ch. VII Hegel, 110
Hering, H. S., 92, 126

Hernia, 182

Hilary, 192

Hill, Rev. Edgar P., 140

Holland, Canon Scott, 112

Holmes, Mrs. A. L., 69, 244

Holmes, Dr. C. E., VI, 244

Holy Communion, Mrs. Eddy on, $160 \mathrm{ff}$

Holy Ghost, see Holy Spirit

Holy Spirit, and Christian

Science, 142, 206

Huber, Dr. John B., VI, 177-180

Huguenots, 193

Human Life, V., 47, 112

Hypnotism, 98, 196, 197, 200 Hypochondria, 198

Hysteria, 198

\section{I}

Idealism of Mrs. Eddy, 20, 138, Ch. V

Imagination, Tyndall's scientific uses of, 120

Incarnation, the, 142

Independent, the, 3

India, snake bites in, 223

Infinite Mind, 109

Insomnia, 198

Irving, W., 70

Isaiah, 163

Isle of Dreams, the, 148

$$
\text { J }
$$

Jacob, well of, 190

James, Professor William, 200, 221, 231

Jeffersonian, the Bangor, 39 Jerome, 192 
Jesus, 2, 31, 114, 142, 153, 155, 205-208, 216; Mrs. Eddy and, 105-107, 143; way of healing, 171, 189 Job, 89, 128

Johns Hopkins University, 126, 198

Johnson, Samue1, 193

Johnston, W. A., 174

Jordan, President David Starr, 227

Journal, Christian Science, 88,153

Judas, 106, 107

\section{$\mathrm{K}$}

Kant, 109, 119

Kennedy, Richard, VI, 34, $46,56,73-75,137,165$

Keyes, Hon. Wade. 238

King's Evil and Charles II., 193

\section{L}

Lanier, Sidney, 152

Lawsuit, see Eddy vs. Frye et al.

Ledger, the New York, 70

Leonardo da Vinci, 100

Leprosy, 172

Libby Prison, 58

Light Brigade, charge of the, 5

Lincoln, Abraham, 72

Lodge, Sir Oliver, 114, 156, 159, 241

Logos, the, Mrs. Eddy's idea of, 146

Lord's Prayer in Christian Science, 160
Lotze, 109

Lourdes, 194

Love and Christian Science, Ch. VIII

Luther, Martin, 193

Lynn, Mass., 58, 66, 72, 78, 86,111

\section{M}

Macleod, Fiona, 148

McClure's, V, 36

McComb, Dr. S., 248

McLellan, A., 92, 147

McGee, Anita Newcomb, 184 Magnetism, Animal, 51, 76, 90, 165-168, 201; “M. A. M.;" see Animal Magnetism.

Mahomet, 95

Malaria, 185

Man, the reflection of God, - 187

Manila, 181

Manual, the, 90, 97-100, $151,211,243$

Mark Twain, see S. L. Clemens.

Marriage and Christian Science, Ch. VIII

Mary, Virgin, 149, 206

Masons, the Free, 55

Massachusetts Metaphysical College, 87, 92, 93

Materialism, 136

Matter and Christian Science, $109,115,186$

Mecca, 95

Medicine, 181

"Medicine Man," the, 199

Medina, 95 
Mental Medicine, Evans's, 43 Mesmer, 51, 91

Mesmerism, see Animal Magnetism

Methodists, 193

Metaphysical College, Mass., 87, 92, 93

Milmine, Georgine, V, 34, 38,77

Mind, Mrs. Eddy on, 109

Mind senses, 118

Miracles, false, 192

Missions, Mrs. Eddy on, 223

Mona Lisa, 100

Moll, Albert, 201

Moody, D. L., 26

Moravians, 193

More, P. E., 251

Mormonism, 77

“"Mortal Mind," 166-168

Moses, 120, 151, 172

Mosley, J. R., 125, 139

“Mother Mary,"' 24, 151

Motherhood of God, 150

Münsterberg, Prof., 67

\section{$\mathrm{N}$}

Nancy, Bernheim at, 60

Napoleon, 50, 97, 107

National Christian Science Association, 88, 151

“Nature," Emerson's Address on, 119

Neo-Platonists, 108

Nero, 76

Nestorianism, 143, 146

Neurasthenia, 198

Newell, Bradley, 194

New England, influence of,
Newhalls, the, 68

New Thought, 17, 198

New York, Christian Science in, 177

Nicæa, Council of, 143

Nightingale, Florence, 184

No and $Y e s, 137$

Norton, Carol, 173

\section{$\mathrm{O}$}

Osler, Dr. Wm., 177, 185, 198

\section{$\mathbf{P}$}

Palsy, 173, 185

Pantheism, 20, 138, Ch. V

Paracelsus, 199

Paralysis, 198

Parker Fraternity Building, 87

Parkhurst, Bishop, 193

Parkyn, 195

Patterson, C. B., 17

Patterson, Dr. Daniel, 57, 66, 81

Patterson, Mrs. Daniel (Mrs. Eddy), 32, 40, 64

Peabody, F. W., VI., 231

Pharisees, 4

Philosophy, Christian Science 20, Ch. V

Pickwick Papers, 70

Pierce, Franklin, 51

Plants, Christian Science healing of, 174

Plato, 108

Pleasant View, 95, 98, 99, $124,184,212$ 
Pleurisy, 248

“P. M. Society," 90

Poe, E. A., 167

Poisons, and Christian Science, 175

Pomponazzi, 199

Portland, Maine, 59

Post, the Boston, 36

Poyen, Charles, 51, 60

Prayer, Mrs. Eddy on, 155

Presbyterians, 193

Principle, 136, 214

Proselyting, 6, 7, 222

Publication, Committee on,

15, 46, 47; see Farlow

Puritans, 193

\section{Q}

Quimby, George A., VI, 71, 228,230

Quimby, P. P., 59, 74, 75, $106,119,139,143-145,165$, $193,201,229,233$, Ch. III Quimby, Mrs. P. P., 38

\section{$\mathrm{R}$}

Rainsford, W. S., 129

Reality, in Christian Science, 116

Reformation, the, 193

Religion of Christian Science, Ch. VI

Revelation, Book of, 148

Rheumatism, 186

Richelieu, 107

Rochester Rapping Spiritualism, 32

Rome, 9
Roosevelt, Theodore, 129

Russells, the, 33, 68

Russo-Turkish War, 182

\section{S}

Sacraments, the, 159

St. Anne, 193

St. James, 26

St. John, 215, 242

St. Luke, 208

St. Mark, 208

St. Matthew, 208

St. Paul, 26, 28, 145, 159, 162,208

Salem witchcraft, 80

Sanbornton Bridge, 53

Sargeant, Mrs. Laura E., 92

Satan, Mrs. Eddy on, 167

Schlatter, 194

Schrader, 194

Science and Health, Ch. II

Scrofula, 193

Senses, soul, 118

Sentinel, Christian Science, 88, 147

Seward, W. H., 72

Shakers, the, 51,52

Siena, Catharine of, 194

Sin, in Christian Science, 162

Small-pox, 172

Smith College, 132, 133

Smith, Judge C. P., 174

Snake bites in India, 223

Soul senses, 118

Southworth, Mrs. 70

Spanish-American War, 182

Spenser, 198

Spinoza, 109

Spirit senses, 118

Spiritualism, 32 
Spofford, D. H., VI, 34, 45, $78-81,82,148,152,165$

Springfield, Mass., 116

Stanton, Edwin M., 72

Stetson, Mrs., 177, 178

Stone, 51

Stoughton, Mass., 69, 119

Straus, 161

Suggestion in mental healing, 197-200

Suicidal tendencies, 198

Supreme Court, Mass., 103

Surgery, 176, 182, 196, 197

Swampscott, Mass., 68

\section{$\mathrm{T}$}

Taft, W. H., 129

Theology of Christian Science, Ch. VI

Therapeutics, Mental, Ch. VII

Thessalonians, 208

Thibet, 132

Tityrus, 123

Tilton, N. H., 53, 55

Tomlinson, Rev. Irving C., 92,223

Town, Dr. F. L., 40

Transcendentalists, the, 109

Trent, W. P., 100

Trinity, the Christian Science, 142

Trinity Church, Boston, 120

Trommer's test, 185

Tuckey, C. Lloyd, 201

Tumors, 185, 186

Tyndall, Prof., 120

Typhoid fever, diagnosis of, $177,181,193$
U

Unity, Mrs. Eddy's search for, 136

“ Universal Substance," Spinoza's, 109

\section{V}

Van Rhenterghem, 195

W

Walcott, Mrs. J. R., VI, 33, 46

Waldenses, 193

War, Civil, 58; Russo-Turkish, 182, Spanish-American, 182

War in Heaven. 91

Ware, the Misses, 60, 61

Websters, the, 69

Weissman, 125

Welles, Mrs. Benjamin, VI

Wentworths, the, VI, 34,46 , 69-72

Wheelers, the, 68

White House, the, 9

Wiggin, Rev. J. H., 38, 166, 226

Wilbur, Sibyl, 47, 48

Will, the, in Christian Science, 165

Willis, John B., 250

Wilson, H. Cornell, 92

Wilson, Woodrow, 129

Wisdom, P. P. Quimby on the, 144

Witchcraft, the modern Salem, 80

Wolsey, Cardinal, 107

Wood, Henry, 17 


\section{INDEX $\quad 26 \mathrm{I}$}

Worcester, Dr. Elwood, 17, | Young, Bicknell, 116, 117, 19, 249 122, 137

Wright, Livingston, VI, 226 $\mathrm{Y}$

Yellow fever, 181

Z

Zend-Avesta, 108 






\section{Date Due}

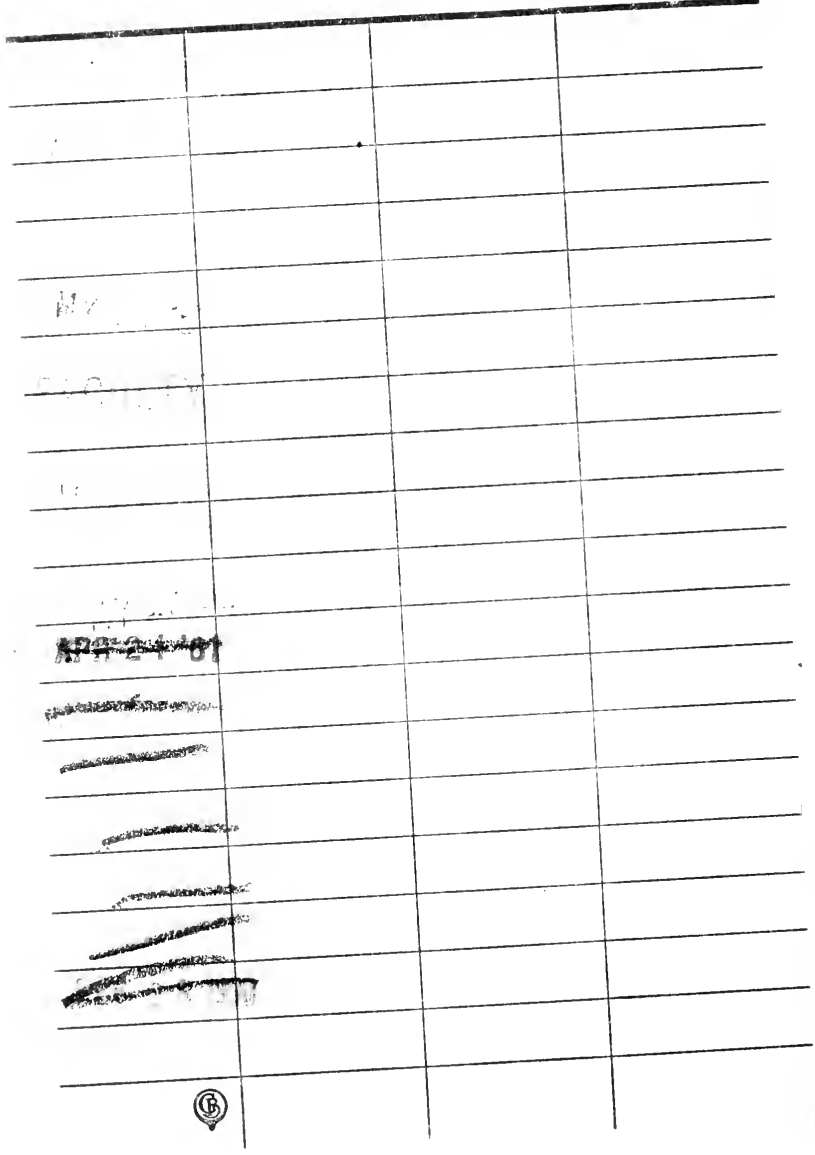



BP943.P88

Christian science the faith and its | || || || || ||||||||||| 11012000381725 